\title{
INDUSTRIAL RELATIONS AND INSTITUTIONAL CHANGE IN SWEDEN: A RESPONSE TO EUROPEAN INTEGRATION
}

\author{
Kelvin Bannan
}

\section{A Thesis}

Submitted to the Victoria University of Wellington in Fulfilment of the Requirements for the Degree of

Master of Arts in Political Science

School of History, Philosophy, Political Science and

International Relations

Victoria University of Wellington

Victoria University of Wellington 2009 


\section{Table of Contents}

Abstract

$\begin{array}{lll}\text { Acknowledgements } & \text { ii }\end{array}$

List of Tables and Figures

List of Abbreviations $\quad$ iv

1.0 Introduction and Methodology................................. 1

$1.1 \quad$ Problem........................................................... 1

$1.2 \quad$ Research questions................................................. 3

$1.4 \quad$ Methodology.................................................. 4

$1.4 \quad$ Structure of thesis............................................... 8

2.0 Literature review............................................... 10

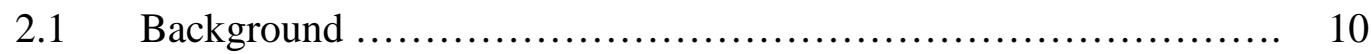

2.2 Approaches to the study of institutions.......................... 11

$2.3 \quad$ One or more capitalisms? ........................................ 15

2.4 Main actors in the creation of labour market institutions............. 19

2.5 How labour market institutions change............................. 24

2.6 Conclusions.................................................. 30

3.0 The Laval Case: Background................................... 32

3.1 Low wage labour in Sweden: the event.......................... 33

3.2 Swedish model of industrial relations............................. 34

$3.3 \quad$ Swedish Law.................................................... 39

$3.4 \quad$ European employment policy................................. 41

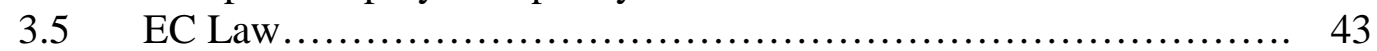

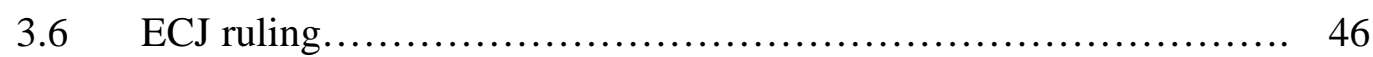

3.7 Different frames in which to view the ECJ ruling.................. 51

3.8 Definitions: legislated minimum wage, erga omnes,

extension model, and status-quo.............................. 53

3.9 Conclusions..................................................... 59 
4.0 Social Partners................................................... 62

4.1 The changing nature of positions.................................. 64

4.2 Legislated minimum wage....................................... 64

4.3 Universal declaration of collective agreements..................... 73

4.4 Extension model ............................................... 76

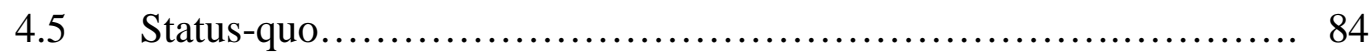

4.6 Conclusion..................................................... 87

5.0 Claes Stråth Investigation and Head Agreement..................... 92

$5.1 \quad$ Structure of the investigation .......................................... 93

5.2 Perspectives from social partners ................................ 98

5.3 Head Agreement .................................................. 104

5.4 Conclusion..................................................... 109

6.0 What this tells us about the Swedish model......................... 112

$6.1 \quad$ Is change occurring?.............................................. 112

6.2 Actors and labour market change............................... 115

6.4 Models of change................................................ 119

6.5 Conclusions................................................... 123

7.0 Conclusion....................................................... 126

$7.1 \quad$ Summary...................................................... 126

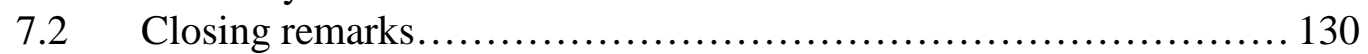

$\begin{array}{ll}\text { Bibliography } & 133\end{array}$

$\begin{array}{lr}\text { Appendices } & 139\end{array}$

I Articles 3(1) and 3(8) of the Posting of Worker Directive 140

II Information sheet 142

III Consent to participation in research $\quad 144$

$\begin{array}{lll}\text { IV Interview schedule } & 145\end{array}$ 



\begin{abstract}
Many observers have identified Europeanization as undermining the foundation of national systems of capitalisms. This paper addresses a national level response. The approach taken assesses the positions (for change) by actors within the Swedish Model toward the 'Laval' European Court of Justice ruling (C-341/05). Through the analysis of position documents and semi-structured interviews with representatives from the social partners, this paper identifies key pressures within the Swedish labour market model in response to the Court ruling. The extension model (autonomous collective agreement model) proved to be the preferred option for the Swedish partners. Concurrently, this model results in the least amount of change to Swedish industrial relations. While a substantial degree of support was identified for 'change', specifically the legislated minimum wage option, institutional structures were identified that restricted such positions from reaching official channels of influence. This case provides evidence of institutional continuity and is an example of national industrial relations proving robust against the forces of European integration.
\end{abstract}




\section{Acknowledgements}

This thesis is a product of 26 years. While the support during my enrolment was invaluable, the inspiration and learning that has occurred up until today cannot be forgotten. I must thank those friends, teachers, and colleagues who have encouraged my interest in university.

I would like to thank the following people, for without their support this project would not be possible. I would like to thank my supervisor John Leslie for encouraging the development of this project starting back in my honours year. Also, for his advice and feedback throughout the year.

I would also like to thank all the staff of the Political Science and International Relations program, particularly those who took me in their undergraduate and honours level programs. And, Elizabeth McLeay for her support of the Masters and PhD students.

Importantly I would like to extend a large thank you to all those who I met and interviewed in Sweden, as well as those who I engaged in correspondence with. This thesis would not be what it is without your assistance. Further, all of you were willing to make time for me in your busy schedules, and went out of you way to make me feel welcome.

I would also like to thank Jon Greenway for lending me a spare room during my trip without your help, this fieldwork would not have been possible (and definitely not as comfortable or enjoyable).

I would like to thank Peter Nunns for his invaluable help and feedback, particularly toward the end of this thesis. I would also like to thank my other colleagues at the Ministry of Economic Development for their support during the last stages.

I must also thank the FHSS for their research grant which also made this study possible.

Most of all I would like to thank my parents John and Zenaida Bannan, for whom without your support and encouragement throughout my life, this would be not possible. 


\section{List of Tables and Figures}

\section{Tables}

$1.1 \quad$ Peak level social partners..................................... 6

3.2 Sweden and EU25 industrial relation indicators.................... 41

$4.1 \quad$ Interview representatives and organisations...................... 63

P.2 Positions of social partners.................................... 88

Figures

$1.1 \quad$ Diagram of Research Problem................................... 4

$2.1 \quad$ Literature Review Diagram ..................................... 30

3.1 Four Wage Setting Models...................................... 59

$5.1 \quad$ Structure of Claes Stråth Enquiry .................................. 95

5.2 Parameters of Claes Stråth Enquiry Diagram......................... 97

6.1 What constitutes change ........................................ 114 


\title{
List of Abbreviations
}

\author{
ALMP Active Labour Market Policies \\ DG Directorate-General \\ EIO Electrical Installer Organization (Elektriska Installatörsorganisationen) \\ EC European Community \\ ECJ European Court of Justice \\ EEC European Economic Community \\ EFTA European Free Trade Area \\ EMU Economic and Monetary Union \\ EP European Parliament \\ ETUC European Trade Union Federation \\ EU European Union \\ Handels Trade Union of Commercial Employees (Handelsanställdas förbund) \\ LO Swedish Trade Union Confederation (Landsorganisationen i Sverige) \\ MBL The Act on Co-determination at Work (1976) \\ PRA Power Resources Analysis \\ TCO Swedish Confederation of Professional Employees (Tjänstemännens \\ Centralorganisation) \\ SACO Swedish Confederation for Professional Associations (Sveriges \\ Akademikers Centralorganisation) \\ SAGE Swedish Agency for Government Employers (Arbetsgivarverket) \\ SAP Swedish Social Democratic Party (Sveriges socialdemokratiska \\ arbetareparti) \\ MP Moderate Party (Moderata samlingspartiet) \\ SwE Confederation of Swedish Enterprise (Svenskt Näringsliv) \\ TF The Association of Swedish Engineering Industries (Teknikföretagen) \\ VoC Varieties of Capitalism
}


1

\section{Introduction and Methodology}

\subsection{PROBLEM}

Regional integration is a pervasive trend taking place at different levels across the globe. Examples abound, but no case is as entrenched, widespread, or institutionalised as the European Union (EU). This political and economic union which began to form only years after the Second World War divided Europe, has emerged as a 'Petri dish' for globalisation. National states that were previously organised as competing mercantilist units now share a common currency, a single monetary policy and a single market in which there is free movement of labour.

This achievement, however, has not come without cost. Europe - like all regions - contains a huge degree of diversity. Its countries are disparate in terms of wealth, size, culture, and institutional arrangements. Within the EU exists competing national identities, perceptions on how societies should be arranged, and attitudes as to what role the 'state' should play in regulating society.

One consequence of this diversity has been a constant tension between national sovereignty and a unified Europe. Integrating such a large number of countries means that 'give and take' is inevitable; there will be winners, but there will also be losers. To achieve a common goal, some countries will be forced to change and may also have to bear disproportionate costs.

Sweden, a relative newcomer to the EU, has recently risen to the forefront of tension between national and EU level institutions. Renowned for its high-standard of living and its position as a leader in almost all international social indicators, Sweden is looked to by many as a successful fusion of market capitalism with strong social and worker protection. 
On 18 December 2007, The European Court of Justice (ECJ) made a ruling which reverberated throughout Sweden and the rest of Europe. The Laval, or Vaxholm, ruling (C-341/05) was viewed by many as a severe blow to aspirations of a social Europe and Sweden's unique style of labour relations. The landmark ECJ case was won by Laval un Partneri, a Latvian company undertaking short-term building renovation in the suburb of Vaxholm on the outskirts of Stockholm. The controversy existed because Laval was employing Latvian workers at Latvian wages. Given that the GDP per capita of Sweden is US\$50, 940, and Latvia is US $\$ 11,870,{ }^{1}$ there was fear that an influx of low-wage workers would mean the end of Sweden's economic and social model.

The ruling stated that certain Swedish labour market institutions were incompatible with European Community (EC) law. In particular, unions could not prevent short-term workers from another EU member state undertaking work in Sweden subject to home conditions. These conditions include significantly lower wages than what is generally acceptable in Sweden. While this is a simplification, it does capture the source of public fear and animosity in Europe toward this ruling and perceptions of the pitfalls of increasing European integration.

The Laval ruling represents an archetypal 'external shock' to a national level institution - in this case the Swedish labour market institutions. Disputes take place in the many institutions of the European Union: the Council, Commission, Parliament, and the European Court of Justice (ECJ). The ECJ, however, has in particular become an interesting arena as it can rule in a manner which can be perceived as a reduction on national sovereignty. ${ }^{2}$ There is criticism of a democratic deficit within the EU institutions, such as the ECJ. ${ }^{3}$ The ECJ Laval case was followed by a succession of similar rulings - Viking (Finland) and Rüffert (Germany) cases - and provoked opposition from both within Sweden and Europe. ${ }^{4}$

\footnotetext{
${ }^{1}$ World Bank, "Gross National Income Per Capita 2008," World Development Indicators Database, World Bank, http://siteresources.worldbank.org/DATASTATISTICS/Resources/GNIPC.pdf.

${ }^{2}$ Larry Siedentop, Democracy in Europe (London Penguin Books, 2001), 25-46.

${ }^{3}$ B Bercusson, "Democratic Legitimacy and European Labour Law " Industrial Law Journal 28, no. 2 (1999): 163-65.

${ }^{4}$ Swedish Parliament, "Response to Interpellations 2007/08: 624, 560, 561, 562, 563 and 582 on Issues on the Occasion of Laval and Rüffert Cases," (Parliamentary Protocol, 2008, May 13), Christin Johansson, "Eu-Hot Mot Kollektivavtal Nonchaleras Av Regeringen (the Eu Threat to Collective Agreements Ignored by Government) " Dagens Nyheter 2008, August 18,
} 
This study is particularly concerned with how national institutions respond to this type of integration. Do institutions converge upon equilibrium, do they remain static, or do they transform incrementally? These are issues that are important to scholars, government, and policymakers in every country. A range of opinions about how Sweden should respond to the ECJ ruling have been voiced. These include change at the European level, change at the national level, or departure from the EU. This has led to the intense debate and a subsequent government enquiry into the possible options in response to this case. The interesting question is what, if any, changes Sweden has taken or is likely to take in response to the ECJ ruling and why. Responses from actors within Sweden provide insights into the process of institutional change (at the national level) and offer an opportunity to understand how national institutions react to the process of regionalisation. Observing these tensions show how compatible the Swedish model of industrial relations is with Europeanisation.

\subsection{RESEARCH QUESTIONS}

To best contribute to the macro-questions outlined above, the questions asked by this study must be narrowed. Pressure for change, in response to the Laval case can be being taken at two levels - the European and the Swedish levels. This particular study will examine the tension that exists at the Swedish national level, rather than looking at why the ECJ ruled the way it did, or integration from the EU perspective.

The research problem begins with an external shock (ECJ ruling) to Swedish labour market institutions. The model can respond in different ways, such as remaining robust or collapsing. An important element of how institutions adapt will be linked to how actors within the labour market model respond. Therefore, this study will examine the response of Swedish actors to the ECJ ruling; particularly it focuses on whether change or continuity can be observed. Figure 1.1 provides a diagram of the research problem.

Thus, this thesis addresses the three following questions:

Anonymous, "A Severe Blow to Sweden's Long Standing Collective Bargaining " Radio Sweden 2007, Dec 19. 
- What are the positions of social partners (unions, employers associations) toward the ECJ Laval ruling (C-341/05)?

- Do institutions play a role in shaping the positions of social partners?

- What can these areas tell us about the pressures within the Swedish model and its propensity for change?

Through addressing these micro-questions on the Swedish model, this study will contribute to the knowledge of how national level institutions respond to regional integration.
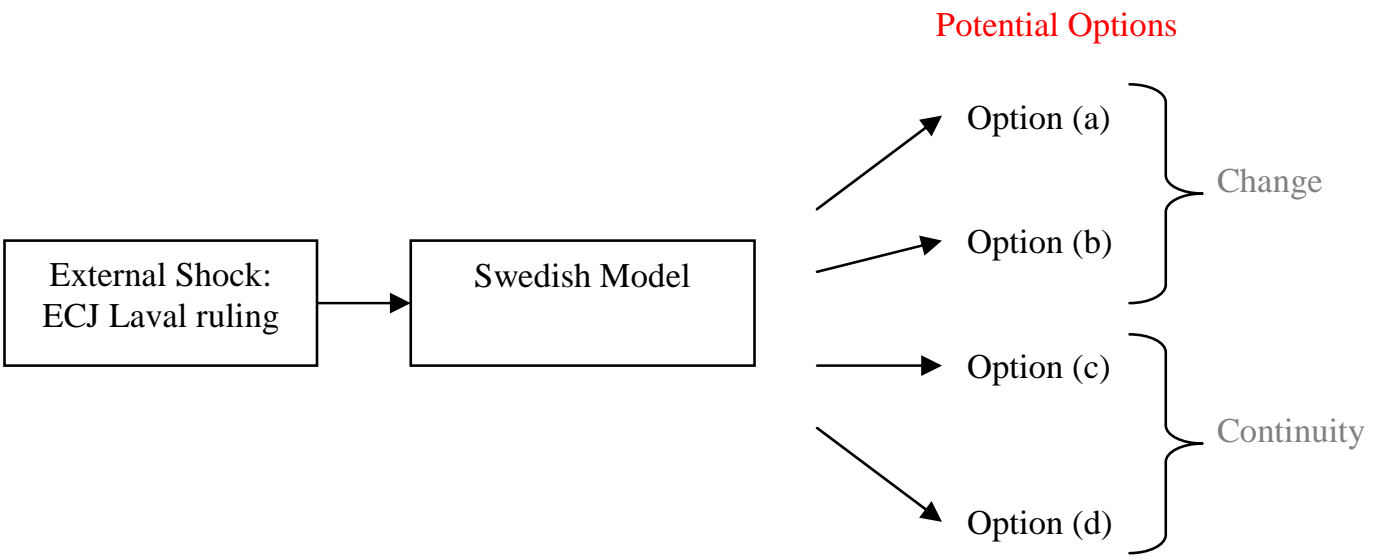

Figure 1.1 Diagram of Research Problem

\subsection{METHODOLOGY}

In order to investigate the conflicts played out in the current 'reorganisation' of the Swedish model, a number of different sources of information are available to this study.

One option is to assess the positions of social partners, government agencies, civil society groups, and public opinion. Upon deeper investigation, the issue is played out in a restricted manner with the peak-level social partners being the most influential and vocal. The way in which political parties interpret the issue is aligned with those of the social partners. 
Thus, this study has taken the approach of assessing the main peak level organisations on both sides of labour and employers (which will be further discussed in the literature review section). The investigation also involves analysis of the core government enquiry on the Laval issue (Claes Stråth investigation) and the renegotiation of the Saltsjöbaden Agreement (Head Agreement).

Three core sources of primary and secondary data have been used. First, positions papers, published statements, and other relevant documentation were sourced from the core actors. Second, 10 face-to-face semi-structured interviews, of approximately 60 minutes in length, were completed with senior officials from the main social partners. ${ }^{5}$ The interviews were used to explore organisation positions to a much greater depth; they were also used to supplement written statements, particularly where a position required elaboration or no official or non-official position papers exist. Those senior officials interviewed consisted of Chief Legal Advisors, Heads of Negotiations, and Directors General. All of the main five social partners were interviewed: Confederation of Swedish Enterprise; Swedish Agency for Government Employers (SAGE); Swedish Trade Union Confederation (LO); Swedish Confederation of Professional Employees (TCO); and Swedish Confederation for Professional Associations (SACO). See Table 1.1 for a description of each of the main social partners. In addition to this were three interviews made up of affiliate organisations of the peak-level social partners: Trade Unions of Commercial Employees (Handels), belonging to LO; and the Association of Swedish Engineering Industries (Teknikföretagen) and the Electrical Installer Organisation (EIO) affiliated to Swedish Enterprise. Additional interviews were made with the Moderate Party (lead political party) and the key government agency Swedish National Mediation Office.

Where needed, written correspondence supplemented interview data. Thirdly, secondary texts were assessed in the form of academic publications (journal articles and books), as well as other reputable analyses from research institutes, government bodies, and non-governmental organisations.

\footnotetext{
${ }^{5}$ Of these 10 semi-structured interviews, 9 were face to face while one was via telephone interview. From the 11 representatives sought by the project, only 10 were used as a suitable representative from the Swedish Social Democratic Party (SAP) was not found. This actor, however, was not as important as the others included in the study. Further, sufficient written documentation on the position(s) of the SAP were obtained.
} 
Table 1.1. Peak Level Social Partners

\begin{tabular}{|c|c|c|c|c|}
\hline & Organisation & Representation & $\begin{array}{l}\text { Membership } \\
\text { Size }\end{array}$ & $\begin{array}{l}\text { Number of } \\
\text { Affiliates }\end{array}$ \\
\hline \multirow[t]{2}{*}{$\begin{array}{l}\text { Employer } \\
\text { Associations }\end{array}$} & $\begin{array}{l}\text { Confederation of } \\
\text { Swedish } \\
\text { Enterprise }\end{array}$ & $\begin{array}{l}\text { Private sector } \\
\text { employers }\end{array}$ & $\begin{array}{l}1.6 \text { million } \\
\text { employers }\end{array}$ & $\begin{array}{l}40 \text { sectoral and } \\
\text { employers } \\
\text { associations }\end{array}$ \\
\hline & $\begin{array}{l}\text { Swedish Agency } \\
\text { for Government } \\
\text { Employers } \\
\text { (SAGE) }\end{array}$ & $\begin{array}{l}\text { Public sector } \\
\text { employers }\end{array}$ & $\begin{array}{l}250 \text { member } \\
\text { agencies }(0.24 \\
\text { million } \\
\text { employees) }\end{array}$ & - \\
\hline \multirow[t]{3}{*}{$\begin{array}{l}\text { Employee } \\
\text { Associations }\end{array}$} & $\begin{array}{l}\text { Swedish Trade } \\
\text { Union } \\
\text { Confederation } \\
\text { (LO) }\end{array}$ & $\begin{array}{l}\text { Blue-collar } \\
\text { employees }\end{array}$ & $\begin{array}{l}1.9 \text { million } \\
\text { employees }\end{array}$ & $\begin{array}{l}16 \text { national } \\
\text { unions }\end{array}$ \\
\hline & $\begin{array}{l}\text { Swedish } \\
\text { Confederation of } \\
\text { Professional } \\
\text { Employees } \\
\text { (TCO) }\end{array}$ & $\begin{array}{l}\text { White-collar } \\
\text { employees }\end{array}$ & $\begin{array}{l}\text { Over } 1 \text { million } \\
\text { members }\end{array}$ & $\begin{array}{l}18 \text { national } \\
\text { unions }\end{array}$ \\
\hline & $\begin{array}{l}\text { Swedish } \\
\text { Confederation } \\
\text { for Professional } \\
\text { Associations } \\
\text { (SACO) }\end{array}$ & $\begin{array}{l}\text { Professional } \\
\text { (university- } \\
\text { trained) } \\
\text { employees }\end{array}$ & $\begin{array}{l}0.56 \text { million } \\
\text { members }\end{array}$ & $\begin{array}{l}26 \text { national } \\
\text { unions }\end{array}$ \\
\hline
\end{tabular}

The study recognised the strengths and limitations of each type of source utilised. Written documentation was particularly useful when it articulated the official position of the organisation. This type of documentation, however, was relatively rare. Unofficial position documents were more common and these varied greatly in level of legitimacy and authority. Additionally, position papers and documents consistently differed in quality and depth, and often addressed a heterogeneous set of issues. ${ }^{6}$

A further limitation was that some actors did not release any statements. The reasons for this varied: sometimes no position existed; other times a position existed but the organisation did not wish to make it public. This important distinction, however, required greater investigation for clarity. In summary, a great deal of difficulty was encountered when trying to obtain standardised information from written documentation. Despite these shortcomings, these documents were used to obtain indications of positions of necessary organisations where available.

\footnotetext{
${ }^{6}$ For a more in depth evaluation of sources see the following: Lisa Harrison, Political Research : An Introduction (New York : Routledge, 2001), 57-71, 89-138.
} 
Semi-structured interviews were used to remedy the shortcomings of written documentation. These interviews provided the core primary source for this study. Semi-structured interviews were particularly successful in the following ways: elaborating on why a position was taken (or not) toward the ECJ Laval ruling; ranking preferred positions; and determining unacceptable and non-negotiable positions. With these strengths and weaknesses in mind, the interviews were devised and conducted in order to gain optimal data quality for this study. Further, compliance with the Victoria University of Wellington ethics standards meant appropriate conduct was followed.

The third type of source used was secondary academic and non-academic texts. These were particularly useful in providing background and contextual information, filling gaps where the scope of this study's primary research did not reach, and triangulation with similar studies. It is important to note that there was, at the time of writing, little published analyses on the Laval case (due to its recent nature); a plethora of previous studies on complementary areas, however, provided a fruitful platform in which to contextualise and evaluate the findings.

This research takes a single case study approach, which as a methodology has particular advantages as well as disadvantages. Comparing 'many cases' has the benefit of being able to generate more widely applicable conclusions. However, in doing so, much of the case specific detail is lost which increases the risk of making oversimplified generalisations. Comparing a few cases (for example Vaxholm, Rüffert and Viking) could provide an alternative starting point for this study, however, the constraints of this thesis mean that such a study would not be feasible. Similarly, much of the Sweden specific factors unique to this case could potentially be 'glossed over'. For a more in-depth discussion on the merits and drawbacks of the number of case studies used it is useful to consult the following: Landman (2003), Lijphart (1971), and Mill (1967).

Using the single case study method is justifiable under the constraints imposed on a MA thesis and for the ability of a case study to support or question the existing literature. It is within the confines of comparative politics as it uses concepts which are used in a comparative context with other countries, and seeks to make a contribution to theory that holds across a number of countries. ${ }^{7}$

\footnotetext{
${ }^{7}$ Landman p 34-35
} 


\section{$1.4 \quad$ STRUCTURE OF THESIS}

To begin this study, Chapter Two will survey the literature on this area. It will determine the scope of previous research, and determine where gaps in previous knowledge exist. It will examine the literature in four broad categories: diverging approaches to how institutions are studied; views on the number and 'types' of capitalism; core actors in the creation of labour market institutions; and most importantly, perspectives on how labour market institutions change. This will determine the framework of analysis for which the remainder of the thesis will be based.

From this point, Chapter Three will provide the background to the study and define the technical terms which will be used in the remaining chapters. It will build upon the introduction to the ECJ Laval dispute by providing an introduction to Swedish law and European law. From here, an overview of the Laval case and its implications will be provided so the positions of the social partners can be sufficiently understood. The next section will define what this study means by the 'Swedish model of industrial relations'. It will define precise parameters in which change or continuity will be measured. The same will be done for European employment policy. The remainder of the chapter will define the major 'positions' that have been considered by the social partners in response to the ECJ ruling (such as erga omnes and legislated minimum wages). With the definitions of the technical terms made clear, the following chapter will analyse the positions of the core actors.

Chapter Four assesses what type of change to the Swedish model actors want following the ECJ Laval ruling. Here, the four most influential models are discussed in turn. First, it evaluates the positions of Swedish actors on the 'legislated minimum wage model' (representing the most change). Secondly, it focuses on the positions surrounding the 'universal declaration of collective agreements model', or 'erga omnes' (representing change, albeit to a lesser degree than the former option). Thirdly, the

study looks at the options under the 'extension model', of which the 'autonomous model of collective agreements' is the most prominent. This option represents little or no change to the Swedish model depending on which variant is advocated. The fourth 
model to be assessed will be the 'status-quo model' that affects domestic and foreign posted workers in different ways.

Chapter Five reviews how the Claes Stråth investigation may affect the success of the social partners in achieving their goals. This chapter assesses this in two core parts. First, it considers the structure of the investigation as well as its directives. From here, it then turns to the perspectives of the social partners. In particularly, it will assess the way in which the investigation may 'aid' or 'hinder' a certain position. Next the analysis continues by turning to the renegotiation of the 'Saltsjöbaden Agreement' or new 'Head Agreement'. It considers the concern of issue linkage and how the timing of the Head Agreement renegotiation may be used to influence the positions of opposed social partners. Particularly, this section focuses on leverage gained by labour representatives over some employer representatives resulting from bargaining power disparities in the Claes Stråth investigation.

Chapter Six, discusses the conclusions of the previous chapters and explores what the findings of this thesis can tell us about the Swedish model. It approaches this in the following manner. Firstly, this chapter assesses the interests of the actors within the model, particularly the role of class solidarity vs. the notion of cross class alliances. Secondly it discusses the institutional constraints of these interests. And thirdly, this chapter clarifies the explanatory value of the 'competing' models of change.

The seventh and final chapter concludes the study. It provides an overview of the aggregate findings of the thesis, alongside a discussion of its implications and areas for further research. 
Anonymous. "A Severe Blow to Sweden's Long Standing Collective Bargaining " Radio Sweden 2007, Dec 19.

Bank, World. "Gross National Income Per Capita 2008." World Development Indicators Database, World Bank, http://siteresources.worldbank.org/DATASTATISTICS/Resources/GNIP C.pdf.

Bercusson, B. "Democratic Legitimacy and European Labour Law " Industrial Law Journal 28, no. 2 (1999): 153-70.

Harrison, Lisa. Political Research : An Introduction: New York : Routledge, 2001.

Johansson, Christin. "Eu-Hot Mot Kollektivavtal Nonchaleras Av Regeringen (the Eu Threat to Collective Agreements Ignored by Government) " Dagens Nyheter 2008, August 18.

Parliament, Swedish. "Response to Interpellations 2007/08: 624, 560, 561, 562, 563 and 582 on Issues on the Occasion of Laval and Rüffert Cases." Parliamentary Protocol, 2008, May 13.

Siedentop, Larry. Democracy in Europe. London Penguin Books, 2001. 


\section{2}

\section{Literature Review}

As introduced, the Laval ECJ ruling (C-341/05) illustrates the tensions between supranational governance (Europeanisation) and national level (Swedish model) institutions in the process of regional integration. The literature on institutionalism is wide. It encompasses competing approaches to the study of institutions, debates over the existence and importance of national models of capitalisms, alongside competing explanations of how institutions are created, maintained, and change. Sweden has been a favourite subject for political economists and comparative political scientists because it has an entrenched welfare state and coordinated market mechanisms alongside exceptional social, economic, political and cultural indicators.

This wealth of information creates both advantages and disadvantages. From a positive outlook, this study does not suffer from an absence of information, and can be enriched from the range of perspectives put forth. The depth and breadth of the works written in this area mean numerous points of view exist around the question of 'institutions'. Care must be taken about how to enter the debate, and how to make a meaningful contribution.

Despite the 'bounty' of information, and perhaps because there is so much debate on this issue, much more work is required in particular areas. Many gaps in the literature exist due to changing dynamics and composition of the EU. In addition to gaps in the literature, ongoing events provide more material to help us understand institutional change.

This chapter addresses the core concern of what is the previous research on the impact of regional integration on national level institutions. Particularly, the impact of European integration on the Swedish industrial relations institutions.

In order to assess institutional change in Sweden (and the impact of the Laval ruling) this study uses three analytical frameworks. The convergence model suggests 
that institutions will converge upon an equilibrium. In other words, Swedish labour market institutions will move toward a European employment policy norm. The second model of the punctuated equilibrium suggests that the Swedish employment model will be robust (during periods of stasis), however, has the propensity to collapse when faced with a critical juncture. The third model, of incremental transformation, characterises Swedish labour market institutions as changing gradually over time, due to the pressures of displacement, layering, drift, conversion and exhaustion.

But these three models of how institutions change are influenced by a number of assumptions. These assumptions include: how to approach the study of institutions; the number of capitalisms that exist; and the main actors in labour market change.

Our starting point is the external shock to Sweden, that of the Laval ECJ ruling. So what can the literature tell us about how institutions respond to an external shock? Do they converge, are the characterised by punctuated equilibrium, or do they transform incrementally? To explore these issues in a meaningful way this study must explain how and why this threefold model has been reached. This chapter begins its review of the literature by discussing different approaches to the study of institutions. Secondly, it will next discuss competing schools of thought on the 'different types of capitalism'. Thirdly, this chapter assesses what the literature can tell us about the main actors in the creation and evolution of the labour markets. Only once each of these areas are addressed will this review the threefold model of convergence, punctuated equilibrium and incremental transformation.

\subsection{APPROACHES TO THE STUDY OF INSTITUTIONS}

The different approaches of the study of institutions have implications for how to undertake the study of labour market change. Three broad perspectives have been identified by various commentators on the 'new institutionalisms'. While these categories are by no means exclusive and overlap to various degree, analytically separating the three is important due to the contrasting assumptions which inform the different approaches. Hall and Taylor (1996) provide a concise overview and evaluation of this 'threefold' typology in Political Science and the Three New Institutionalisms. Of particular concern to this study, as well as other institutionalist 
approaches, is that it demarcates two issues': (1) the role of institutions on 'social and political outcomes' or the behaviour of actors; as distinct from (2) the origins of institutions and the conditions under which they are subject to change. While it is the second of these issues that this study is most concerned with, there are often strong links between both of these aspects.

An important observation by Hall and Taylor (1996) is that there has been polarisation between the three approaches, particularly along disciplinary lines and methodology. ${ }^{2}$ They also observed that the different approaches developed somewhat 'independently' from each other, with scarce dialogue between them. ${ }^{3}$

Rational choice institutionalism holds the strictest behavioural assumptions. It assumes that actors operate subject to fixed preferences and rational self-interest. ${ }^{4}$ Accordingly, the scholars who use this approach view the creation of institutions in a particular way; specifically the function of an institution is conceptualised as resulting from institutional design. ${ }^{5}$ In other words, institutions are the result of "voluntary agreements' by the actors concerned in order to ensure mutually beneficial gain. ${ }^{6}$ Thus, the rational choice institutionalism approach is defined as highly functionalist.

Explanations of change informed by rational choice instituionalism are explicitly linked to assumptions above. Primarily, institutions are viewed to exist so long as the associated actors benefit from them. A shift in the pay-offs actors receive from them may result in actors wanting to reshape institutions so as to meet their changing interests. $^{7}$ While some authors praise the theoretical elegance of rational-choice institutionalism, they have been criticised as empirically insignificant and oversimplistic. $^{8}$

\footnotetext{
${ }^{1}$ Peter A Hall, Rosemary C R. Taylor, and "Political Science and the Three New Institutionalisms," Political Studies Vol. 44, no. Iss. 5 (1996): 936-37.

${ }^{2}$ A preliminary classification identifies the following: rational choice insitutionalism being linked with economics and quantification; historical institutionalism being linked with Political Science; and sociological institutionalism with Sociology and qualitative methodology.

${ }^{3}$ This argument is made by Hall and Taylor with an evaluation of the cross-referencing in the literature. P 937

${ }^{4}$ Kathleen Thelen and Sven Steinmo, "Historical Institutionalism in Comparative Politics," in Structuring Politics : Historical Institutionalism in Comparative Analysis ed. Sven Steinmo, Kathleen Thelen, and Frank Longstreth (Cambridge [England] ; New York : Cambridge University Press, 1992).

${ }^{5}$ Hall, Taylor, and "Political Science and the Three New Institutionalisms," 944-45.

${ }^{6}$ Ibid.: 945.

${ }^{7}$ Ibid.

${ }^{8}$ See Karen Schweers Cook and Margaret Levi, eds., The Limits of Rationality (Chicago

University of Chicago Press, 1990).
} 
Historical institutionalism (HI) takes a different view of institutions, based on a different set of assumptions. HI depicts temporal processes and historical events as important in shaping institutions that are crucial in informing preferences. ${ }^{9}$ In other words actors behave according to institutional rules that define their strategies. Thus in contrast to rational choice institutionalists, $\mathrm{HI}$ recognises the presence and legacies of existing institutions.

Hall and Taylor identify four characteristics of HI. First, HI has much broader assumptions concerning the effect of institutions on actor behaviour. ${ }^{10}$ Asymmetries in power relations shape how institutions operate and develop. ${ }^{11}$ Furthermore, historical institutionalism is more likely to include other variables, such as ideas, into the institutional analysis. ${ }^{12}$ This willingness to encompass the complexities of institutional and individual behaviour enriches the approach. The core critique of this literature is its propensity to generalise, as opposed to making coherent theoretical contribution. Further, it places a strong focus on path-dependence, which contributes to a more static view of institutions. ${ }^{13}$ In addition unintended consequences have a tendency to be a driver in $\mathrm{HI}$ analysis.

Overall, HI has been very successful in explaining how institutions maintain themselves over time as a result of reinforcing mechanisms. ${ }^{14}$ Many authors have suggested that its strength at explaining continuity comes at the expense of explaining change and transformation. ${ }^{15}$

Sociological institutionalism offers an explanation of institutions removed from the focus of rationality and/or temporal processes. Sociological institutionalism, as defined by Hall and Taylor, views institutions as primarily 'culturally-specific practices' which are integrated into organisations. ${ }^{16}$ Thus, explanations by sociological institutionalists focus on "institutional forms, procedures or symbols ${ }^{17}$ which proliferate in a particular sphere (such as a nation or field).

\footnotetext{
${ }^{9}$ Thelen and Steinmo, "Historical Institutionalism in Comparative Politics," 7-10.

${ }^{10}$ Hall, Taylor, and "Political Science and the Three New Institutionalisms," 938.

${ }^{11}$ Ibid.

${ }^{12}$ Ibid.

${ }^{13}$ Ibid.

${ }^{14}$ Thelen and Steinmo, "Historical Institutionalism in Comparative Politics," 21-2.

${ }^{15}$ See Thelen 1999

${ }^{16}$ Hall, Taylor, and "Political Science and the Three New Institutionalisms," 946.

${ }^{17}$ Ibid.: 947.
} 
Thus, Hall and Taylor characterise sociological institutionalism as having three core implications for institutional analysis. Firstly, sociological institutionalism provides a wider definition of institutions. The sociological definition of institutions includes 'symbol systems, cognitive scripts, and moral templates that provide the frames of meaning guiding human interaction. ${ }^{18}$ This extends part the definition of institutions generally used by $\mathrm{HI}$ political scientists that include formal rules, procedures and norms. ${ }^{19}$

Secondly, institutions are viewed to influence the behaviour of individuals inducing actors to 'internalise norms' associated with particular roles. ${ }^{20}$ Thus, institutions prescribe behaviour because what actors believe to be rational is in itself socially constructed. ${ }^{21}$

A third characteristic of this approach is its view on the motivations for the implementation and maintenance of an institution. Here it is assumed that institutions have the purpose of increasing 'social-legitimacy' of the actors concerned. ${ }^{22}$ This stands in contrast to end goals of 'efficiency' and provides an explanation for why particular institutions are upheld despite hindering the 'end-goals' of particular actors.

A valid critique of this approach, however, is its tendency to overlook any agency within actors. Rather it sees agency to be 'conditioned' by respective institutions. This can overlook power struggles within particular institutional arrangements. ${ }^{23}$

Thus, the literature approaches the study of institutions in different ways through rational choice, historical and sociological institutionalisms. This is particularly true with reference to the initial assumptions around institutions and their relationship to actors. While this section provides a snapshot of the different analytical approaches, combinations of these approaches are more often used. Nevertheless, it highlights the importance of initial assumptions in the study of institutions. Particularly, it suggests the need for analytical clarity around the role of actors; particularly, whether their interests are endogenous or exogenous to institutions, or both. Furthermore, these assumptions have implications for institutional change. Different theories hold that

\footnotetext{
${ }^{18}$ Ibid.

${ }^{19}$ Ibid.

${ }^{20}$ Ibid.: 948.

${ }^{21}$ Ibid.: 949.

${ }^{22}$ Ibid.

${ }^{23}$ Neil Fligstein, The Transformation of Corporate Control (Harvard University Press 1993), 295-316.
} 
actors rationally create institutions, history and institutional legacies matter, or that actors' prescriptions for changing or creating institutions are socially constructed from previous or existing institutional structures.

The literature has illustrated a wide range of assumptions surrounding the study of institutional change and the effect of actors. It strongly supports the importance and relevance of historical and institutional legacies; but this study will also not ignore any agency displayed by actors in the Swedish system. Due to the constraints of this thesis, however, the manner in which institutions construct preferences will not be a focus of the study. In light of this, the Historical Institutionalist framework has the greatest relevance for this study of Swedish labour market institutions. The next section discusses the number of 'types of capitalisms' that exist and its implications for the study of institutional change.

\subsection{ONE OR MORE CAPITALISMS?}

Another controversy concerns whether one or many types of capitalisms exist. This has implication for convergence and punctuated equilibrium models. If institutions converge, do they converge on one type of capitalism or on different types? This issue is particularly important to the study of Sweden and the European Union. An underlying assumption of this thesis is that Sweden does embody a 'unique' type of capitalism, of which the Swedish model of industrial relations is an integral component.

Political economists have particularly placed an emphasis on divergent political and institutional arrangements that may form national models of capitalism. This view, embedded in the HI institutionalist approach, sees different types of capitalist economies organised and operating around the globe. For example the structure of the United States economy differs to Germany, and both differ to Sweden. Not all scholars, however, accept this idea that more than one type of capitalism exists. This section will unpack the diverging literature.

Two primary categories can be demarcated: first, there are those authors who take the assumption that there is only one form of capitalism. ${ }^{24}$ Those within this school are

\footnotetext{
${ }^{24}$ Particularly post-war modernisation theorists, and those authors that follow from Max Weber's ideal-type. For further discussion see Colin Crouch, "Models of Capitalism," New Political Economy 10, no. 4 (2005).
} 
likely to adhere to neo-liberal explanation and prescriptions for economic and social advancement. The second category is composed of those who argue that different 'types' of capitalisms exist in advanced western democracies. This literature is collectively referred to as Varieties of Capitalism (VoC). Within the VoC approach, however, diversity continues to exist. This particularly concerns the main unit of analysis: welfare states or firms.

The view of a single type of capitalism has not been popular within the schools of institutionalism. Authors that take this view hold the assumption that the effects of globalisation are inevitable, and that it is a driving trend toward homogeneity. ${ }^{25}$ Modernisation theorists have been significant proponents of this approach. ${ }^{26}$ While it might recognise diversity between nation states, it does not see any institutionally distinctive groups of economies. Rather, it believes that the differences between economies such as the US and Sweden are overstated. Each country has a unique economic structure, and differences do not warrant multiple capitalist classifications.

This school of thought draws parallels to earlier authors' views of capitalist development in 'evolutionary' terms. ${ }^{27}$ Particularly, different countries are identified as passing through different stages of the same historical process. Examples of this include approaches that follow from Max Weber's 'ideal-type' method. ${ }^{28}$ Similarly, followers of Antonio Gramsci's approach classified Fordism as an evolutionary, or natural, successor of classical free-market liberalism. ${ }^{29}$ Of the scholars that this study will draw from, however, most have undertaken substantial work in illustrating and explaining how different types of 'capitalisms' have come about.

Authors who agree that countries fall into different types of capitalist organisation argue that countries are not necessarily on the same evolutionary track. Rather, they conceive of multiple tracks. Despite this shared starting point, however, continued diversity exists.

For example, there may be consensus that the USA and Germany constitute separate camps, but some argue that Germany and Sweden do not exhibit the structural difference to be characterised a 'different types' of capitalism. The discussions on the

\footnotetext{
${ }^{25}$ Ibid.: 439.

${ }^{26}$ Adam Przworski and Feranado Limongi, "Modernization: Theories and Facts," World Politics 49, no. 2 (1997): 155-83.

${ }^{27}$ Crouch, "Models of Capitalism," 439.

${ }^{28}$ Ibid.

${ }^{29}$ Ibid.
} 
models of capitalism are centred on two primary approaches, one group of authors who classify economies according to their production side, and those authors who classify according to the consumption side.

First, authors influenced by the works of scholars such as Esping-Andersen characterise countries according to their consumption side, with a focus on the type of welfare state. This analysis primarily began with a threefold classification of advanced western democracies: Liberal Market Economies (LME), Co-ordinated Market Economies (CME), and Social Market Economies (SME). A second group of authors, such as Hall and Soskice, demarcate countries by their production side and the structure of the private sector. Here the types of capitalisms are limited to two primary groups: LME's and CME's. In order to progress to the discussion of institutional change, the next section will discuss the scholarship in these divergent areas.

The scholarship on the 'consumption side' draws upon the work of Gosta EspingAndersen. In the book The Three Worlds of Welfare Capitalism (1990), EspingAndersen argues that the welfare state, which falls into three broad groups, is paramount to the development of current models of capitalism. ${ }^{30}$ In other words, social policy (and thus welfare regimes) are tied to the labour market model as the welfare regime is used in differing degrees to clear the labour market, to ease entry and exit (for example, retirees and mothers), or as being a source of employment. ${ }^{31}$ As a consequence, the relationship between welfare regime and the labour market results in a distinct post-industrial trajectory; this is evidenced in Germany, Sweden, and the US by the differing role of government involvement in employment growth, the distinct internalisation of services within firms, and the differing levels of managerialism. ${ }^{32}$

In the follow up work by Esping-Andersen (1999) Social Foundations of Postindustrial Economics the previous framework is tested alongside more recent empirical evidence. Esping-Anderson also addressed critiques directed toward the 1990 work and, for example, extends the threefold typology (of LME, CME, and SME) to include a Mediterranean model that was previously grouped under CMEs. As a whole, however, Esping-Andersen still held the role of institutions, namely the institutional relationship between the labour market structure, changes in family life (such as

\footnotetext{
${ }^{30}$ Gosta Esping-Anderson, The Three Worlds of Welfare Capitalism (Princeton, N.J. : Princeton University Press, 1990), p5.

${ }^{31}$ Ibid., pp144-62.

${ }^{32}$ Ibid., pp191-221.
} 
structure and participation in paid employment), and tertiarisation (or globalisation), as core features of national state trajectories. ${ }^{33}$ In response to domestic or international changes, the nature of industrial relations and the structure of the labour market institutions are seen as shaping and determining the outcomes which take place. Thus, using the Nordic example, distinct labour market institutions result in different outcomes (such as levels of unemployment) when compared across a number of different countries. ${ }^{34}$

Works that draw from consumption-side welfare state categorisation focus on the way in which welfare states influence the type of 'capitalism' displayed in a particular country. This approach has, however, come under criticism by another group of authors who believe that welfare state explanations are limited.

Hall and Soskice pioneered an approached that classified types of capitalisms according to 'production' criteria. In their 2001 work 'Varieties of Capitalism' Hall and Soskice react against the three previous perspectives on institutional variation. They argue that some literature focuses too strongly focus on the state (in terms of its influence over the private sector). Furthermore, they critique work that categorise countries according to their organisation of the trade union movement. Hall and Soskice wanted to emphasise variation between national political economies. This is because it held that the most important institutional structures depend on national regulatory regimes, such as labour market regulation, education and training, and corporate governance. ${ }^{35}$ They based their comparison on the organisation of the private sector. They wanted to make firms the centre of analysis.

Particularly they wanted to move more toward a particular approach of how institutions affect behaviour: this is through affecting strategic interaction resulting in a game-theoretical system. Using these principles, Hall and Soskice identify two types of capitalism: LME's and CME's.

\footnotetext{
${ }^{33}$ Gosta Esping-Andersen, Social Foundations of Postindustrial Economies (New York : Oxford University Press, 1999), p119.

${ }^{34}$ Ibid., pp120-43.

${ }^{35}$ Peter A. Hall and David Soskice., eds., Varieties of Capitalism : The Institutional Foundations of Comparative Advantage (Oxford [England] ; New York : Oxford University Press, 2001), 46.
} 
Different authors have identified other approaches that extend past the twofold typology of capitalist countries. ${ }^{36}$ Richard Whitely in Divergent Capitalisms (1999) places his focus on East Asian nations (such as Japan, Korea, and Taiwan); this has had the effect of removing the focus on the 'liberal' vs. 'coordinated' binary which has dominated analyses which focus on Europe and North America. ${ }^{37}$ Whitely identifies six typologies of business systems that are based upon sociological models of capitalism. ${ }^{38}$

Due to the evidence of the literature, this study will adopt the broad assumption that multiple 'types' of capitalisms exist. But what causes institutions to change? We have taken the assumption of multiple types of capitalism. It is dependent on what the analysis is focused upon as to what type of change that will take place.

\subsection{MAIN ACTORS IN THE CREATION OF LABOUR MARKET INSTITUTIONS:}

While there is agreement that institutional diversity falls into categories, further debate surrounds the question of who the driving actors are in the creation of labour market institutions. An analysis of institutional change that places a focus on labour will be different to an analysis that focuses on employers as the main actors.

In the literature we identify three broad schools of thought on the core drivers in the development of labour market institutions. The first set of authors takes a 'labour centred' view and perceive labour market institutions (and welfare state development) as concessions made as a consequence of class conflict. A second set of authors, to the contrary, place an emphasis on the role of employers (and cross-class alliances), rejecting this labour-centred approach. Further, a third group of authors argues that this binary approach of labour and employers relationship being labelled as 'partnership or alliance' or 'adversarial or conflictual' is overly simplistic and that factions can occur regarding areas of distribution production.

\section{Employee based explanations}

\footnotetext{
${ }^{36}$ For a highly developed fivefold typology see Bruno Amable The Diversity of Modern Capitalism

${ }^{37}$ Crouch, "Models of Capitalism," 448.

${ }^{38}$ Ibid.
} 
So what can theories that explain labour as the core driver in the creation of labour market institutions tell us about institutional change in Sweden? Walter Korpi has long been a proponent of the school which sees labour markets and welfare states being the result of class conflict. This is also known as Power Resources Analysis (PRA) with the assumption that wealth, resources, and knowledge and access to power are unequally distributed. ${ }^{39}$ Thus it places a focus on 'distributive conflicts' in labour markets. The lower resources held by individual employees gives rise to "class-related collective action'. Political parties representing 'labour' are expected to be the core drivers behind the welfare state, and labour market institutions which favour employees; employers are not assumed to take an opposing role in these developments. ${ }^{40}$ Thus, Sweden's large welfare state (and 'employee friendly' labour market structure) is viewed as the result of concessions won by strong unions and Social Democratic Parties. In other words, the type of welfare model found in a country is a reflection of the strength of unions and left-wing parties. ${ }^{41}$

In his 2006 article, Korpi argues vehemently against analyses that focus on crossclass alliances as the main drivers of welfare states and labour market institutions. He is particularly critical of authors who discount class (and PRA) in favour of employer centered explanations. ${ }^{42}$

Korpi believes that VoC scholars have substantially misinterpreted the countries used as case studies. The article argues that it is important to demarcate between three different types of actors. There are the protagonists who are responsible for the initiation of welfare state expansion; there are consenters, who only become involved in later stages; and finally there are antagonists who continually oppose welfare state expansion. ${ }^{43}$ Korpi argues that the core VoC scholars have used the label 'protagonist' to include 'consenters' framing employers as playing a much larger role than they had

\footnotetext{
${ }^{39}$ Walter Korpi, "Power Resources Approach Vs. Action and Conflict: On Causal and Intentional Explanations in the Study of Power "Sociological Theory 3, no. 2 (1985): 40-1. 40 _ States and Varieties of Capitalism: Protagonists, Consenters, and Antagonists," World Politics 58, no. 2 (2006): 168.

${ }^{41}$ Kåre Vernby, "Classes, Sectors and Political Cleavages," in Power and Institutions in Industrial Relations Regimes: Political Science Perspectives on the Transition of the Swedish Model, ed. PerOla Öberg and Torsten Svenssen (Stockholm, Sweden: National Institute for Working Life, 2005).

${ }^{42}$ Korpi, "Power Resources and Employer-Centered Approaches in Explanations of Welfare States and Varieties of Capitalism: Protagonists, Consenters, and Antagonists," 201-06.

${ }^{43}$ Ibid.: 182.
} 
in reality. Thus, he argued that class interests and PRA explanations still provide the most convincing explanations, if the order of preferences is taken in to account and employers are recognised as consenters. ${ }^{44}$

The lead role of labour in driving the development of labour market institutions is supported by a range of empirical evidence, such as that offered in Classes, Sectors and Political Cleavages (2005) by Kåre Vernby. Vernby undertakes a broad analysis of actors in Sweden to determine whether class or sectoral perspectives hold the greatest explanatory power in elucidating "political cleavages over economic and welfare policy'. ${ }^{45}$ In this study, Vernby found that 'well defined class interests' were the most important political cleavages. ${ }^{46}$ This was particularly evident between blue and white collar unions vis-à-vis organised business irrespective of the associated sector. ${ }^{47}$ Some sectoral division did exist; however, class appeared to be the most important variable in this case.

Employee centred approaches tell us that weak labour will cause a deterioration of the Swedish model that is favourable to workers. Given the ECJ ruling has weakened unions and empowered employers, we should expect the Swedish model of industrial relations to change as a result of the case toward the interests of employers.

\section{Employer based explanations}

Employer focussed explanations interpret the effects of the ECJ ruling in Sweden in a starkly different manner to the former. The PRA literature, which focuses on class explanations, has occurred alongside - and been involved in a dialogue with - authors who see cross-class alliance and employer-centric explanations to be the most convincing.

In Capitalists against Markets : The Making of Labor Markets and Welfare States in the United States and Sweden (2002), Peter Swenson provided an influential argument for the role of employers in the development of the welfare state in the United States and Sweden. Contrary to PRA analyses, Swenson illustrates the role of employers in pushing to enhance aspects of the welfare state and the protective

\footnotetext{
${ }^{44}$ Ibid.: $182-83$.

${ }^{45}$ Vernby, "Classes, Sectors and Political Cleavages," 121.

${ }^{46}$ Ibid., 117-21.

${ }^{47}$ Ibid.
} 
characteristics of labour market. He shows how from the 1950s onwards employers in Sweden were active in the expansion of the welfare state; this however, did not occur in the US that had a different capitalist model. ${ }^{48}$ In Sweden, the interests of employers and labour overlapped, and the result was a cross-class alliance in favour of a solidaristic model. The consequence of these observations is that if employer interests coincide with labour interests, an analysis that ties the cohesion and organizational strength of union to the size of the welfare state and labour market structure is subsequently undermined. ${ }^{49}$ In other words, an analysis of labour against capital is conceptually discredited if the two groups have worked for the same cause.

Thus, Swenson argued that PRA has not taken into account the core role of employers in welfare state development. In contrast to an explanation where the welfare state is the result of class conflict, or where the 'left' had gained concessions, he argues that the welfare state developed in recognition of employers' interests. Cross-class alliances developed between employees and employers in the same sector.

Swenson and Pontusson (2000) further develop this 'employer led' analysis in the The Swedish Employer Offensive against Centralized Wage Bargaining. They discuss a change in preferences among employers to 'dismantle' a system which they had previously supported (that of centralized wage bargaining in Sweden). ${ }^{50}$ This too argues against the assumption that labour market structure (in this case 'centralised bargaining') reflects the gains of unions and left-wing political parties. Rather, it illustrates that the presence of centralized bargaining is largely the result of the preference of employers. Thus, two explanations are provided for the decline of centralized bargaining in Sweden during the 1990s. ${ }^{51}$ The first explanation was a change in the wage bargaining system that deviated from the original norm. ${ }^{52}$ The second is that a change in production strategies of employers to favour 'flexibility' led to a desire to decentralize the wage setting system. ${ }^{53}$ These descriptions significantly

\footnotetext{
${ }^{48}$ Peter A. Swenson, Capitalists against Markets : The Making of Labor Markets and Welfare States in the United States and Sweden (New York: Oxford University Press, 2002), 47-99.

${ }^{49}$ Ibid., 9-12.

${ }^{50}$ Peter Swenson and Jonas Pontusson, "The Swedish Employer Offensive against Centralized Wage Bargaining," in Unions, Employers, and Central Banks: Macroeconomic Coordination and Institutional Change in Social Market Economies ed. Torben Iversen, Jonas Pontusson, and David Soskice (Cambridge University Press 2000), 81-84.

51 Ibid., 79.

${ }^{52}$ Ibid., 84-88.

${ }^{53}$ Ibid., 91.
} 
explain the level of centralization in wage bargaining by the preference of employers; this is counter to analyses which emphasis the size and strength of unions.

The employer centred approach suggests that the increased power given to employers by the ECJ ruling does not necessarily prescribe a change for the Swedish model. To the contrary, stronger employers will create a stronger model of Swedish industrial relations, as they too are core drivers. In sum, if VoC interpretations prove to hold the greatest explanatory value, we can expect the Swedish model on industrial relations to hold, unless the interests of employers shift.

\section{Dual typology simplistic}

A third group of authors, however, argues that both employer and labour-centered approaches are overly simplistic. Svensson and Öberg (2002) make an important contribution to this area in Power and Trust: Mechanisms of Cooperation. They argue that in an examination of changes within the Swedish model, it is necessary to look at the ways and mechanisms in which the actors within the regime are able to influence public policy-making. Svensson and Öberg assess this area by looking at whether Swedish Labour market organisations influence public policy-making to a significant degree. ${ }^{54}$ Their findings, based upon survey data, suggest that the participation of social partners and interest groups within the Swedish model of industrial relations has decreased but is still significant. A reduction in formally institutionalised participation has generally been compensated for by informal non-institutionalised participation. ${ }^{55} \mathrm{~A}$ dual system has developed in non-institutionalised participation: employers organisations have stronger informal links to public servants and bureaucracy, whereas labour unions have stronger informal ties to politicians and political parties. ${ }^{56}$ Studies such as Petersson et al. (1997) provide evidence for the existence of a dual-elite system in Sweden. ${ }^{57}$ In aggregate, a strong argument can be made that the social partners (both unions and employers) remain highly significant actors in Swedish politics.

\footnotetext{
${ }^{54}$ Torsten Svensson and PerOla Öberg, "Labour Market Organisations' Participation in Swedish Public Policy-Making," Scandinavian Political Studies 25, no. No. 4 (2002): 296.

55 Ibid.: 297.

${ }^{56}$ Ibid.: 302-09.

${ }^{57}$ Ibid.: 296.
} 
Much of this influence, argued by Svensson and Öberg, can be attributed to the strong informal links between the LO and the SAP. It is questionable, however, to what degree this continues to hold today, given government control by the centre-right, 'Alliance for Sweden', coalition.

Huzzard and Nilsson (2004) further illustrate the complexities which may enhance understanding of the polarised 'employers' vs. 'labour' literature. In 'Dancing Queen? : Partnership, Co-Determination and Strategic Unionism in Sweden' they ask whether there have been changes to the forms of partnerships between labour and employers and the relation to collective bargaining. The article argues that both have changed ${ }^{58}$ Huzzard and Nilsson illustrate that there is partnership in the following areas: on distributional goals within white-collar unions; and production issues within blue-collar unions. Adversarial relations were identified, however, on distribution goals between blue-collar unions. In summary, the article argues that labeling the strategic choices of unions as adversarial or partnership is overly simplistic. Rather, it can vary depending on what type of issue, in this example, distribution vs. production issues. ${ }^{59}$

The nature of this study, and the way it analyses the positions of both 'employers' and 'labour', seeks to avoid some of the inherent biases that may exist in an analysis that focuses on one or the other. We have discussed the actors that influence institutions, and now seek to examine how institutions change.

\subsection{HOW LABOUR MARKET INSTITUTIONS CHANGE:}

Here we return to the initial problem of 'models of institutional change'. The above sections review the literature on the dynamics of institutions. This includes multiple views on the existence of competing capitalisms and the role of social actors in analyses.

This section outlines explanations of the way in which institutions change. There are three broad models which are used in the literature to explain the types of change that may occur. Within these models, however, further diversity exists, particularly

\footnotetext{
${ }^{58}$ Tony Huzzard and Tommy Nilsson, "Dancing Queen? : Partnership, Co-Determination and Strategic Unionism in Sweden " in Strategic Unionism and Partnership : Boxing or Dancing? , ed. Tony Huzzard, Denis Gregory, and Regan Scott (Houndmills, Basingstoke, Hampshire ; New York, N.Y. : Palgrave Macmillan, 2004), 86-107.

${ }^{59}$ Ibid., 96-102.
} 
concerning the 'assumptions' of the literature discussed above (for example there is a combination of employer and labour centred perspectives).

The first model of convergence argues that institutions converge on one equilibrium. The second model of punctuated equilibrium views institutions as static entities with multiple levels of equilibrium that change only in response to large crises that call for institutional overhaul. The third explanation of incremental transformation describes institutions that are going through gradual processes of change, rather than institutional overhaul at a critical juncture.

To begin, the convergence literature argues that national level institutions converge upon a single equilibrium. In other words, labour market institutions in Europe are moving toward a single type; this is likely to be a more liberal or deregulated labour market.

The issue of convergence has been approached in two general ways. Firstly, there are authors (such as proponents of modernisation theory) who take the assumption that there is one type of capitalism. For them, institutional convergence is tied to the 'inevitable effects of globalisation', as discussed above. The second group of authors takes the assumption of multiple types of capitalism. Such analyses are distinctive from the first group of authors in a number of ways. These authors argue that institutions convergence within particular groupings of states.

Authors such as Sykes argue for institutional convergence of the second type. Sykes et al (2001) draws from Esping-Andersen's previous work to assess the changing nature of the welfare state in response to globalisation and Europeanisation. The processes of globalisation and Europeanisation were found to be the internationalisation of enterprises, deregulation of financial markets, and European Monetary Union (EMU) convergence. ${ }^{60}$ Recognising that diversity exists between the Nordic states, it was identified that there were shared pressures, evidenced by national shifts. ${ }^{61}$ Underlying trends in the Nordic legacy were found suggesting that economic and welfare policy is not significantly affected by changes in government, but rather by external challenges.

The punctuated equilibrium model has been perhaps the most influential explanation for institutional change over the past two decades. Until recent years it has

\footnotetext{
${ }^{60}$ Robert Sykes, Bruno Palier, and Pauline M. Prior, Globalization and European Welfare States (Palgrave Macmillan 2001), pp159-64.

${ }^{61}$ Ibid., p166.
} 
been the dominant analytical framework for understanding institutional change and has greatly influenced the studies on institutional change within advanced democracies. The argument is drawn from evolutionary biology, particularly critiques against 'the conventional Darwinian synthesis' which views evolutionary progress as slow. This perspective, inaugurated by the widely cited article by Stephen Krasner, 'Approaches to the State: Alternative Conceptions and Historical Dynamics', places emphasis on the need to conceptually distinguish between periods of institutional stasis, and periods of institutional creation. ${ }^{62}$ Other scholars who have developed this theory include Ikenberry (1989), Almond (1973), and Kelly (1994). ${ }^{63}$

Proponents of the punctuated equilibrium model argue that a particular distinction needs to be made between periods of institutional creation and institutional stasis. In other words, the conditions that explain the initial creation of an institution, particularly a period of crisis, will be quite distinct to the conditions that explain its continuity and stasis. $^{64}$

A moment of institutional creation is normally referred to as a 'critical juncture', where the structural influence of political action is significantly reduced for a short period of time. Structural factors include economic, cultural, ideological and organisational influences. ${ }^{65}$ The main consequences are two-fold: the range of choices open to powerful actors expands, and the consequences of their decisions are substantially more influential. Critical junctures are relatively short periods of time in which there is increased probability of actors' decisions affecting outcomes. ${ }^{66}$

Periods of institutional stasis are normally explained as path-dependent processes. These comprise of frameworks such as lock-in, increasing returns, and sequencing. ${ }^{67}$ In

\footnotetext{
${ }^{62}$ Stephen D. Krasner, "Approaches to the State: Alternative Conceptions and Historical Dynamics " Comparative Politics 16, no. 2 (1984): 240.

${ }^{63}$ John Ikenberry, David Lake, and Michael Mastanduno, eds., The State and American Foreign Economic Policy (Ithaca, NY: Cornell University Press, 1989), Gabriel Almond, Scott Flanagan, and Robert Mundt, eds., Crisis, Choice and Change : Histoical Studies in Political Development (Boston: Little Brown, 1973), Sean Kelly, "Punctuated Change and the Era of Devided Government," in New Perspectives on American Politics, ed. Lawrence Dodd and Calvin Jillson (Washington DC: Congressional Quarterly Press, 1994).

${ }^{64}$ Krasner, "Approaches to the State: Alternative Conceptions and Historical Dynamics ": 240.

${ }^{65}$ Giovanni Capoccia and Kelemen R Daniel, "The Study of Critical Junctures: Theory, Narrative, and Counterfactuals in Historical Institutionalism," World Politics 59, no. 3 (2007): 343.

${ }^{66}$ Ibid.: 348.

${ }^{67}$ Ibid.: 343.
} 
'Increasing Returns, Path Dependence, and the Study of Politics', Pierson characterises 'path dependence processes' or 'increasing returns' as having four core features.

One feature is the concept of inertia. This suggests that the positive feedback effects of an institutional arrangement may lead to a single equilibrium. Once this equilibrium has been created, divergence is difficult. ${ }^{68} \mathrm{~A}$ second feature is the importance of timing and sequencing. This maintains that the timing of an event is crucial as to whether increasing returns processes are created. If an event occurs 'too late' or 'too early' it may have a negligible affect; correctly timed events, however, can have lasting consequences. ${ }^{69}$ This links to the third issue of contingency. ${ }^{70}$ Here, small events can have large consequences - many of which are unintended. The fourth feature is the idea that a number of outcomes are possible from the process of increasing returns. This suggests there are potentially multiple equilibrium possible under which institutional arrangements may develop along. ${ }^{71}$

Scholars have come to criticise the punctuated equilibrium model, largely according to weaknesses in explaining those 'critical junctures' in which change occurs, despite its strengths in explaining the periods of 'continuity'. Streeck and Thelen have developed theory that explains institutional change in a different way from the 'convergence' and 'punctuated equilibrium' models.

Streeck and Thelen explain how institutions may change incrementally over lengthy periods of time, rather than abruptly at 'critical junctures' or calamitous events. In 'Beyond Continuity: Institutional Change in Advanced Political Economies' (2005) Streek and Thelen compile a collection of authors who develop a critique of 'mainstream theories' of institutional change and continuity. They argue that much of the punctuated equilibrium literature has a propensity to ignore 'real' changes, labeling any change as 'variations of the old'. ${ }^{72}$ They draw upon authors who view the main weakness of 'path-dependent' and 'lock-in' explanations as their inability to explain

\footnotetext{
${ }^{68}$ Paul Pierson, "Increasing Returns, Path Dependence, and the Study of Politics," American Political Science Review 94, no. 2 (2000): 263.

${ }^{69}$ Ibid.

${ }^{70}$ Ibid.

${ }^{71}$ Ibid.

${ }^{72}$ Wolfgang Streeck and Kathleen Thelen, eds., Beyond Continuity: Institutional Change in Advanced Political Economies (Oxford University Press, 2005), 16.
} 
why institutions change. A particular example of this is the phenomenon of a shrinking welfare state in many western democracies, including Sweden. ${ }^{73}$

An important difference between the 'incremental transformation' and 'punctuated equilibrium' literatures is what may cause 'change'. In Streek and Thelen (2005) the authors focus on changes that occur endogenously, from actors within the institution. A particular focus is the 'gaps' that form between the design and realisation of the institution. In the words of Streeck and Thelen, these openings develop over time to become:

sites of political contestation over the form, functions, and salience of specific institutions whose outcome may be an important engine of institutional change. ${ }^{74}$

In other words, ambiguities that may exist, particularly around the enforcement and purpose of an institution, become arenas of strategic political struggle. In contrast to punctuated equilibrium models, where change usually occurs in response to large external shocks, this new model illustrates how ongoing power struggles within existing institution may cause 'real' gradual change. ${ }^{75}$ Thus, Streeck and Thelen find a compromise between rational choice and historical institutional explanations; while agency exists, it is only exerted within constrained parameters.

The work constructs a typology of how incremental change may take place. It identifies five gradual processes of transformative change: displacement, layering, drift, conversion, and exhaustion. ${ }^{76}$ Displacement is characterized by the assumption that an 'institution' may be founded on a number of different (and even contradicting) 'logics' or 'sub-institutions'. Some will remain subordinated or 'latent', however, may be promoted by certain actors to become dominant. Thus, formally marginalized 'subinstitutions' may come to greater prominence and change the institution. ${ }^{77}$ Layering describes a different process whereby new provisions are added to an existing institution, gradually 'crowding' out its existing functions. ${ }^{78}$ Drift refers to deliberate

\footnotetext{
73 Ibid., 17.

${ }^{74}$ Ibid., 19.

75 Ibid.

${ }^{76}$ Ibid.

${ }^{77}$ Ibid., 19-22.

${ }^{78}$ Ibid., 22-24.
} 
neglect leading to a 'slippage' of institutional practice. ${ }^{79}$ Conversion refers to certain actors capturing an existing institution for a different purpose than originally intended. ${ }^{80}$ And finally, exhaustion refers to the gradual breakdown of an institution over time. ${ }^{81}$ The first four refer to institutional change, while the fifth model suggests institutional breakdown.

Streeck and Thelen make a significant assumption, however, that there is a 'dominant trend' toward liberalization. In particular, they emphasise the ease of individuals in 'opting out' over increased difficulty in implementing collective coordination. Subsequently it argues that these five processes are leading to gradual change characterized by a liberalization of advanced political economies. ${ }^{82}$

In 'Europeanisation of Social Partners in Smaller European Democracies', Falkner and Leiber (2004) illustrate examples of incremental transformation in Austria, Denmark, Luxembourg, and Sweden. This study assesses the impact of 'Europeanisation' on the mechanisms around national policy-making on labour market issues; it does this by focusing on six European employment directives. Denmark displayed the largest impact from Europeanisation. It cited social partner autonomy moving to complementary legislation. ${ }^{83}$ In the assessment of Sweden, it was noticed the effects of Europeanisation were subtle, and more in line with the experiences of Austria and Luxembourg.

The light convergence, identified in the four countries, can be explained using Thelen's fivefold typology of incremental transformation. It shows how institutions may change gradually overtime as distinct to punctuated equilibrium or convergence models.

The three models - convergence, punctuated equilibrium, and incremental transformation - will form the framework to explain the dynamics of the Swedish industrial relations model in response to the ECJ Laval ruling.

\subsection{CONCLUSIONS:}

\footnotetext{
${ }^{79}$ Ibid., 24-26.

${ }^{80}$ Ibid., 26-29.

${ }^{81}$ Ibid., 29-30.

${ }^{82}$ Ibid., 33.

${ }^{83}$ Gerda Falkner and Simone Leiber, "Europeanization of Social Partnership in Smaller

European Democracies?," European Journal of Industrial Relations 10, no. 3 (2004): 258.
} 
This chapter has provided a snapshot of the current literature that helps to explain institutional change. Figure 2.1 provides a summary of this chapter. The literature offers three broad approaches to the study of institutions; each of these varies depending on the type of assumptions taken. The limitation of rational choice institutionalism and the broad scope of sociological institutionalism suggested that historical institutionalism would be the most relevant approach in order to study Swedish labour market institutions and European integration. Here, the study takes the assumption that temporal processes and historical events do play a significant role in producing institutional legacies that influence preferences.

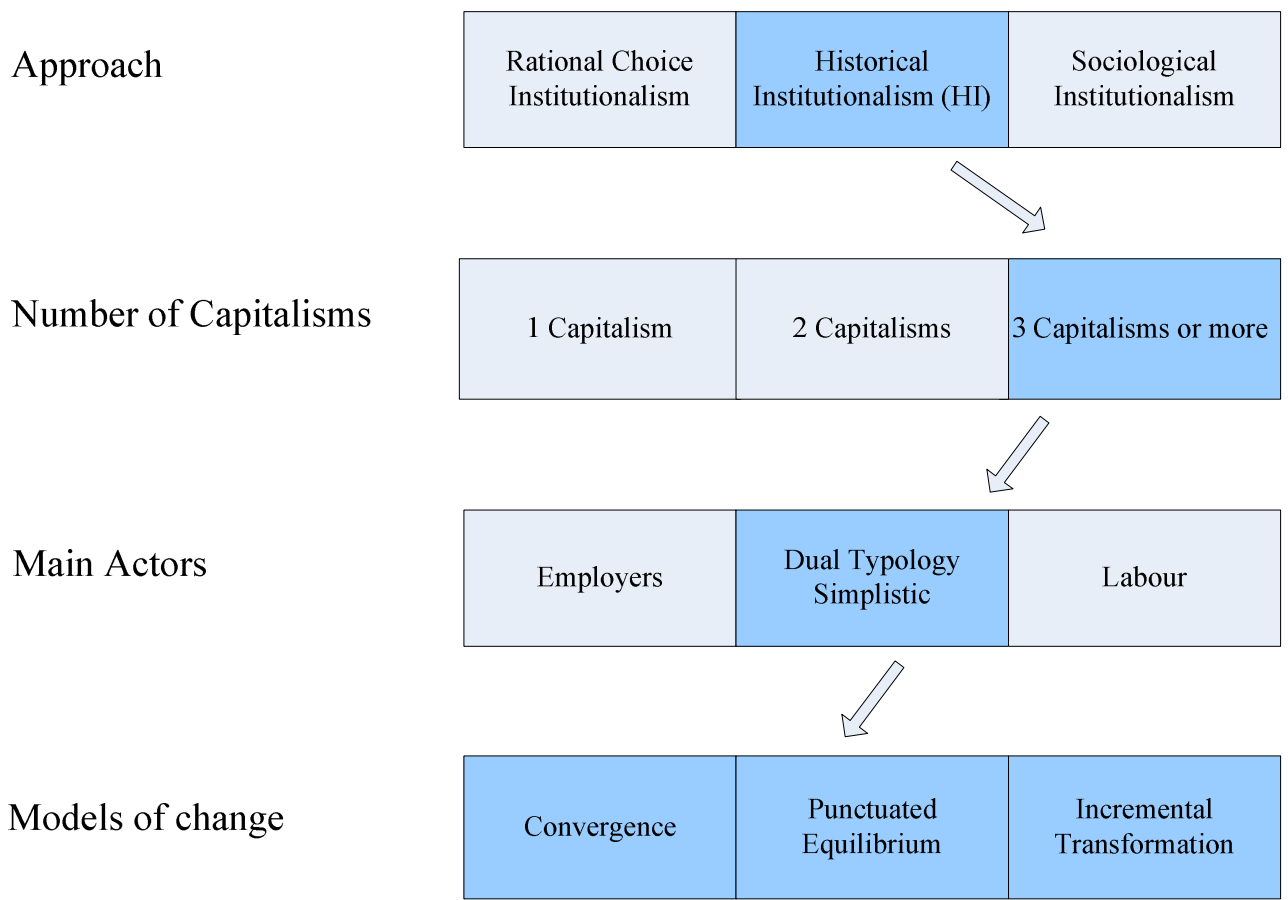

Figure 2.1 Literature Review Diagram

The leading question of this study - how institutions change - provides an indication of another assumption concerning the number of capitalisms that exist. The typology of 'one type of capitalism' proved to be insufficient as a framework for 
this particular study. This is reinforced by the relevant supporting literature that takes the premise of the existence of multiple types of capitalisms.

The literature contained different views on the main actors in the creation of labour market institutions. The polarisation between employer centred versus labourcentred approaches appeared to be overly simplistic. Therefore, it is important to take into consideration the third model which goes beyond this, and proposes that employers and labour are neither universally antagonistic nor always in alliance.

Finally, the literature on how institutional change occurs was examined. Three primary models have been identified in the scholarship, each prescribing different explanations for the way in which institutions change. The first perspective of convergence holds that national level institutions converge upon a single equilibrium in the long run. Punctuated equilibrium places an emphasis on alternating periods characterised of 'institutional stasis' and 'institutional creation'. The third theory of incremental transformation provides an explanation of how institutions evolve over time. These theories will be tested against the empirical findings of the study in order to determine which have the greatest explanatory value in this case.

With this framework taken into account, the remainder of the study can now be conducted. The next chapter will outline the background to the Laval case. It will define the subject areas relevant to this study: the Vaxholm dispute; the Swedish model and Swedish law; European employment policy and EC law; competing frames in which the ECJ ruling is viewed; and finally, definitions for competing options for change considered by the Swedish social partners. 
Almond, Gabriel, Scott Flanagan, and Robert Mundt, eds. Crisis, Choice and Change : Histoical Studies in Political Development. Boston: Little Brown, 1973.

Capoccia, Giovanni, and Kelemen R Daniel. "The Study of Critical Junctures: Theory, Narrative, and Counterfactuals in Historical Institutionalism." World Politics 59, no. 3 (2007): 341-69.

Cook, Karen Schweers, and Margaret Levi, eds. The Limits of Rationality Chicago University of Chicago Press, 1990.

Crouch, Colin. "Models of Capitalism." New Political Economy 10, no. 4 (2005). . "Models of Capitalism." New Political Economy 10, no. 4 (2005): 43956.

Esping-Andersen, Gosta. Social Foundations of Postindustrial Economies: New York : Oxford University Press, 1999.

Esping-Anderson, Gosta. The Three Worlds of Welfare Capitalism: Princeton, N.J. : Princeton University Press, 1990.

Falkner, Gerda, and Simone Leiber. "Europeanization of Social Partnership in Smaller European Democracies?" European Journal of Industrial Relations 10, no. 3 (2004): 245-66.

Fligstein, Neil. The Transformation of Corporate Control Harvard University Press 1993.

Hall, Peter A, Rosemary C R. Taylor, and "Political Science and the Three New Institutionalisms." Political Studies Vol. 44, no. Iss. 5 (1996): p. 936 (22 pages).

Hall, Peter A., and David Soskice., eds. Varieties of Capitalism : The Institutional Foundations of Comparative Advantage Oxford [England] ; New York : Oxford University Press, 2001.

Huzzard, Tony, and Tommy Nilsson. "Dancing Queen? : Partnership, CoDetermination and Strategic Unionism in Sweden " In Strategic Unionism and Partnership : Boxing or Dancing? , edited by Tony Huzzard, Denis Gregory and Regan Scott: Houndmills, Basingstoke, Hampshire ; New York, N.Y. : Palgrave Macmillan, 2004.

Ikenberry, John, David Lake, and Michael Mastanduno, eds. The State and American Foreign Economic Policy. Ithaca, NY: Cornell University Press, 1989.

Kelly, Sean. "Punctuated Change and the Era of Devided Government." In New Perspectives on American Politics, edited by Lawrence Dodd and Calvin Jillson. Washington DC: Congressional Quarterly Press, 1994.

Korpi, Walter. "Power Resources and Employer-Centered Approaches in Explanations of Welfare States and Varieties of Capitalism: Protagonists, Consenters, and Antagonists." World Politics 58, no. 2 (2006): 167-206. . "Power Resources Approach Vs. Action and Conflict: On Causal and Intentional Explanations in the Study of Power " Sociological Theory 3, no. 2 (1985): 31-45.

Krasner, Stephen D. "Approaches to the State: Alternative Conceptions and Historical Dynamics " Comparative Politics 16, no. 2 (1984): pp. 22346. 
Pierson, Paul. "Increasing Returns, Path Dependence, and the Study of Politics." American Political Science Review 94, no. 2 (2000): 251267.

Przworski, Adam, and Feranado Limongi. "Modernization: Theories and Facts." World Politics 49, no. 2 (1997): 155-83.

Streeck, Wolfgang, and Kathleen Thelen, eds. Beyond Continuity: Institutional Change in Advanced Political Economies: Oxford University Press, 2005.

Svensson, Torsten, and PerOla Öberg. "Labour Market Organisations' Participation in Swedish Public Policy-Making." Scandinavian Political Studies 25, no. No. 4 (2002): 295-315.

Swenson, Peter A. Capitalists against Markets : The Making of Labor Markets and Welfare States in the United States and Sweden: New York: Oxford University Press, 2002.

Swenson, Peter, and Jonas Pontusson. "The Swedish Employer Offensive against Centralized Wage Bargaining." In Unions, Employers, and Central Banks: Macroeconomic Coordination and Institutional Change in Social Market Economies edited by Torben Iversen, Jonas Pontusson and David Soskice: Cambridge University Press 2000.

Sykes, Robert, Bruno Palier, and Pauline M. Prior. Globalization and European Welfare States: Palgrave Macmillan 2001.

Thelen, Kathleen, and Sven Steinmo. "Historical Institutionalism in Comparative Politics." In Structuring Politics : Historical Institutionalism in Comparative Analysis edited by Sven Steinmo, Kathleen Thelen and Frank Longstreth, 1-33: Cambridge [England] ; New York : Cambridge University Press, 1992.

Vernby, Kåre. "Classes, Sectors and Political Cleavages." In Power and Institutions in Industrial Relations Regimes: Political Science Perspectives on the Transition of the Swedish Model, edited by PerOla Öberg and Torsten Svenssen, 107-26. Stockholm, Sweden: National Institute for Working Life, 2005. 


\section{3}

\section{The Laval Case: Background}

The first chapter defined how this thesis will research the impact of the ECJ Laval case and document the positions of the social partners toward the courts ruling. The second chapter followed this with a discussion of the literature on which this study will draw. Before this study can proceed, however, it must introduce a number of contextual factors and definitions. First, this chapter will reintroduce the Laval dispute and the Vaxholm conflict. From here, it will outline the Swedish context: it will define the Swedish model of industrial relations, followed by a discussion of Swedish law. Next, the European context will be introduced, starting with European employment policy, followed by EC law.

Once the Swedish and European contexts have been introduced, the chapter will embark on an in-depth discussion of the ECJ Laval ruling (C-341/05). The ruling, however, is multifaceted and has been interpreted in a number of different ways. To address this issue, the chapter will include a discussion of the competing frames in which the ECJ ruling is viewed. This is necessary in order to understand the positions that have been taken by the social partners and under what areas agreement or disagreement arise. The final section will discuss the key terms that the social partners use in discussing changes to the Swedish model in response to the ECJ case. It will define the four core options for national level change: legislated minimum wage, universal extension of collective agreements or erga omnes, extension model (autonomous collective agreements), and the status-quo model. These discussions will provide context for the remainder of the study. But to begin, the next section will return to the period of Sweden's initial accession into joining the EU, when the seeds of the Laval case were sown. 


\subsection{LOW WAGE LABOUR IN SWEDEN: THE EVENT}

Sweden formally joined the European Union on January $1^{\text {st }} 1995$. At this time, all countries in the European Union were categorised as high-income states, except for (geographically distant) Spain, Portugal, and Greece. As a result, the issue of 'posted workers' - employees undertaking short term work in a foreign country - had not posed a significant problem to any of the existing states. The landmark 1990 ECJ ruling Rush Portuguesa (Case C-113/89, Rush Portuguesa $\mathrm{Ld}^{\mathrm{a}}$ v Office national d'immigration), between Portuguese posted workers in France, set the precedent that community law does not prevent nation states from implementing national legislation, allowing for national re-regulation ${ }^{1}$.

On May $1^{\text {st }} 2004$, the Eastern Enlargement took place in which eight new Eastern Bloc countries joined the European Union (Latvia, Lithuania, Poland, Slovakia, Slovenia, Czech Republic, Estonia, and Hungary). Within a month of this event the municipality government of Vaxholm, in metropolitan Stockholm, was one of the first entities to make commercial use of the Eastern Enlargement. For the purpose of undertaking building renovations for a school, they tendered a contract to prospective companies including firms from new EU member states.

The winner of the contract was Latvian company Laval un Partneri Ltd (Laval) and its subsidiary $L \& P$ Baltic $A B$. Swedish trade union, Bygnnads, attempted to create a collective agreement with Laval but it was without success. Instead, Laval concluded two collective agreements with the Latvian Workers Union. ${ }^{2}$ The use of Latvian workers at Latvian wages and outside of a Swedish Collective Agreement resulted in Bygnnads giving written notification for industrial action on $19^{\text {th }}$ October 2004 to blockade the building site. ${ }^{3}$ Sympathy action was taken by the Electricians Union on 3 December $2004 .^{4}$ As work on the site subsequently ceased, L\&P Baltic AB went into receivership. $^{5}$

\footnotetext{
${ }^{1}$ Georg Menz, "Re-Regulating the Single Market: National Varieties of Capitalism and Their Responses to Europeanization," Journal of European Public Policy 10:4 (2003): 539-41.

${ }^{2}$ Kerstin Ahlberg, Niklas Bruun, and Jonas Malmberg, "The Vaxholm Case from a Swedish and European Perspective," Transfer 12, no. 2 (2006): 6.

${ }^{3}$ Ibid.

${ }^{4}$ Ibid.

${ }^{5}$ Ronnie Eklund, "The Laval Case," The Industrial Law Journal 35, no. 2 (2006): 202.
} 
Laval brought the case to the Swedish Labour Court (A268/04) under the justification that the action taken by the Swedish trade unions was unlawful. On 15 September 2005 the Swedish Labour Court published a preliminary ruling stating that Laval's case did not fit the criteria for unlawful trade unions action. ${ }^{6}$ In 2005 Laval brought the case to the European Court of Justice. On 23 March 2007, Advocate General Mengozzi (belonging to the ECJ) released an opinion in support of the Swedish Labour Courts ruling against Laval. ${ }^{7}$ This led many to believe the final ECJ ruling would support the Swedish Labour Court's ruling. However, the final judgment from the ECJ, released on 11 December 2007 (3 years after the actual dispute), ruled in favour of Laval. It concluded that Swedish labour union action in this case was unlawful. ${ }^{8}$ In other words, the ECJ ruled contrary to the Swedish Labour Court's preliminary ruling, stating the actions of Laval in using workers under a Latvian collective agreement was consistent with EC law.

In order to understand what grievances are held by the Swedish social partners and what this ruling means for labour relations, the Swedish perspective will be introduced.

\subsection{THE SWEDISH MODEL OF INDUSTRIAL RELATIONS}

The following section will outline the Swedish model of industrial relations. The Swedish model has different characteristics when described as: a social and cultural model; an economic model; or as a particular arrangement for industrial relations. It is the third feature - the Swedish model as a particular set of industrial relations - that is important in this study.

To address this issue, this section will take a fivefold path. To begin, it will discuss the origins of the Swedish model, followed by an introduction to the core characteristics of the model. Next, the section will discuss the feature of solidarism and its relationship to the Rehn-Meidner model. Finally, it will critique the typology constructed.

\footnotetext{
${ }^{6}$ Swedish Labour Court Ruling A268/04 p 1

${ }^{7}$ Norbert Reich, "Free Movement V. Social Rights in an Enlarged Union: The Laval and Viking Cases before the European Court of Justice " German Law Journal 9, no. 2 (2008): 127.

${ }^{8}$ Ibid.
} 
There are three broad conceptions of the origins of the Swedish model. The first concept is that the Swedish model is the result of class concession made on the side of labour. According to Stewart Wood, it had its origins in the struggle between the elites of classes exposed to industrialisation and the depression of 1873 to $1886 .{ }^{9}$

A second view is that the Swedish model is result of a cross-class alliance between labour and capital responding to a distinct type of capitalism. ${ }^{10}$

A third concept is that the Swedish model is a legacy of Sweden's unique historical factors, in particular its position as a relative late industrialiser in the late nineteenth century (vis-à-vis its Continental and Anglo-Saxon neighbours). Such preconditions, along with popular movements such as the religious revivalist movement, temperance movement, and the labour movement, led to the development of several institutions which were to ultimately form Sweden's corporatist labour structure. These historical processes resulted in the formation of the Swedish Trade Union Confederation (LO), the Swedish Employers Confederation (SAF) and, at the nexus between the two, the Swedish Social Democratic Labour Party (SAP). ${ }^{11}$ A strong labour movement developed with two wings: the LO which took its place in workplaces, and the SAP which constituted the political wing. Employers developed the SAF, which was the main representative for employers. These institutions formed the core of Sweden's corporatist labour structure. ${ }^{12}$

Whichever perspective is chosen, it is clear that a particular model of social and economic relations developed in Sweden which is distinct from the rest of Europe and Great Britain. As noted earlier, this study assumes that Sweden still has a unique model.

The Swedish model of industrial relations has been significantly shaped by historical factors. Two main events are the Saltsjöbaden Agreement and the

\footnotetext{
${ }^{9}$ Alexander Davidson, Two Models of Welfare : The Origins and Development of the Welfare State in Sweden and New Zealand, 1888-1988 (Uppsala: Academiae Ubsaliensis, 1989), 59.

${ }^{10}$ Peter Swenson and Jonas Pontusson, "The Swedish Employer Offensive against Centralized

Wage Bargaining," in Unions, Employers, and Central Banks: Macroeconomic Coordination and Institutional Change in Social Market Economies ed. Torben Iversen, Jonas Pontusson, and David Soskice (Cambridge University Press 2000), Peter A. Swenson, Capitalists against Markets : The Making of Labor Markets and Welfare States in the United States and Sweden (New York : Oxford University Press, 2002).

${ }^{11}$ Davidson, Two Models of Welfare : The Origins and Development of the Welfare State in Sweden and New Zealand, 1888-1988, David Rueda and Jonas Pontussion, "Wage Inequality and Varieties of Capitalism," World Politics Baltimore: Apr 2000 Vol.52, Iss. 3; pg. 350 (2000).

${ }^{12}$ This ideas stem from: Alexander Gerschenkron, Economic Backwardness in Historical Perspective (Cambridge: Belknap Press, 1962), 5-30.
} 
constitutionally enshrined right to industrial action. In the post-war era there was significant conflict between the two peak level organisations, resulting in large strikes that were harmful to both labour and industry. In 1938, a new agreement between the SAF and the LO provided 'labour peace, constructive co-operation on issues of common interest, and a strong emphasis on collective bargaining as a better way of solving problems of employment relations rather than through legislation. ${ }^{, 13}$ This new agreement, called the Saltsjöbaden Agreement, was signed between the two main confederations with the objective of maintaining industrial peace. This 'head agreement' is a cornerstone of the Swedish model.

A second important aspect of the Swedish model is the guarantee to the right to industrial action (in addition to the freedom of association). This right is entrenched in Article One of the Swedish Constitution. ${ }^{14}$ The result has been a system of corporatism, in which autonomous social partners engage in tri-partite or peak-level bargaining.

This collective method of industrial relations regulation, that takes place outside of state control, allowed for the development of labour and employment relations based on the solidaristic model. This is a core aspect of the Swedish labour market coordination. It is distinct from the Segmentalist model which is archetypal of the US and Anglo-Saxon countries. The key differences between the two is the price of labour and the availability of labour.

In the example of Segmentalism labour is overpriced, and there is a surplus of employees within a dual labour market characterised by wage spread. In this model, firms act according to a decentralised strategy in which they aim to provide higher wages and benefits to attract and maintain a desirable labour force. ${ }^{15}$ The overpricing of labour and the associated surplus of workers gives firms additional leverage vis-à-vis employees. This system has a self-reinforcing equilibrium, as there is no incentive for firms or workers to 'opt out'. ${ }^{16}$ The result, however, is a dual labour market; often it results in very high wages for skilled workers (where there is a shortage) coinciding with low wages for low skilled workers.

\footnotetext{
${ }^{13}$ Nils Elvander, " Two Labour Market Regimes in Sweden," Industrielle Beziehungen. 10, no. s (2003): 147

${ }^{14}$ EIRO, "Sweden Industrial Relations Profile," European Industrial Relations Observatory, http://www.eurofound.europa.eu/eiro/country/sweden.htm.

${ }^{15}$ Swenson, Capitalists against Markets : The Making of Labor Markets and Welfare States in the United States and Sweden, pp24-29.

${ }^{16}$ Ibid., p25.
} 
In the solidaristic model labour is under-priced and, in a labour market characterised by wage compression, there is a shortage of workers. This reflects a collective approach where unions - with the support of employers - impose a ceiling on the benefits and wages paid to workers. ${ }^{17}$ This results in wages being under-priced subsequently leading to a scarcity of labour. There is 'a queue of employers' while workers are scarce, giving labour organisations a high degree of bargaining power. The tensions in this model pertain to the system not being in a natural equilibrium. In other words, there is an incentive for firms to 'opt out' and pay higher wages to attract workers. In order for this system to work in the long term, there needs to be cooperation between employers and unions, and an absence of 'cheating'. Cheating may benefit the individual firm or individual workers, but it comes at the expense of the wider arrangement which benefits all parties. ${ }^{18}$

Wage compression or solidarity was, however, part of wider Rhen-Meidner economic model that the newly emerging 'Swedish Model' was to draw heavily from. The Rhen-Meidner model differs significantly from neo-classical models of labour relations, which have prevailed since the 1980s. The objective of the Rhen-Meidner model is to raise low-skilled wages and limit high-end wages to place pressure on the businesses which were less profitable. The consequence is that capital collects in the most efficient industries thereby facilitating growth; firms that are reliant on cheap labour correspondingly go out of business. ${ }^{19}$ This, however, was only part of the model.

In this model, the state has an important role in facilitating the transfer of labour from declining to emerging industries by actively 'up-skilling' workers. Thus, an underlying feature of the Rhen-Meidner model is a large public sector, active labour market policies (ALMP's) ${ }^{20}$, social welfare system, and a state that is active in driving economic development. The result of this state driven model was that the Swedish

\footnotetext{
${ }^{17}$ Ibid., p29.

${ }^{18}$ Ibid., pp19-36.

${ }^{19}$ Jonas Pontusson and Peter Swenson, "Labor Markets, Production Strategies, and Wage Bargaining Institutions: The Swedish Employer Offensive in Comparative Perspective," Comparative Political Studies April no. 29 (1996): 228.

${ }^{20}$ Supply side investment, training, and relocation programs to enhance labour mobility (Blyth, 2001)
} 
economy developed around core industries that were medium to high wage, and away from low-skilled industry. ${ }^{21}$

The Swedish model of labour relations, however, has been subject to many challenges and has not existed in any 'pure' form since its formation in the early twentieth century. It developed on top of a set of ideational foundations of the RhenMeidner model. The Rhen-Meidner model was not always destined to become the underlying theory behind the Swedish model, and rather resulted from the contestation between certain groups. Before 1950 the SAP favoured an alternative model, the Rubbestad model. ${ }^{22}$ By the late 1950s, within policy circles, the Rhen-Meidner model gained supremacy in government policy making. ${ }^{23}$ Throughout the remainder of the twentieth century the Rhen-Meidner model had become consolidated in what we call the 'Swedish Model', although there were also efforts to undermine the model. ${ }^{24}$

A labour offensive took place in the 1960s and 1970s in the form of repeated strike action, suggesting the model was not meeting the 'wage demands of labour'. ${ }^{25}$ Furthermore, the strikes reflected dissatisfaction with the structure of authority (such as lack of union influence in the workplace) in firms. ${ }^{26}$ In the 1980s and 1990s exporting employers staged an offensive, led by the Engineering Employers' Federation, with the aim to decentralise the wage bargaining process. They managed to shift the wagebargaining process from the national to industry level, but were unsuccessful in moving it to the firm level. ${ }^{27}$

Alongside these factors, encroaching legislation has been identified throughout these times. Despite this, minimum wages have remained in the exclusive hands of the social partners.

A liberalisation of regulations preceded the economic recession during the 1990s and an evolution of these corporatist institutions. ${ }^{28}$ By the end the 1990s, many of the core aspects of the Swedish Model had been re-established, with the new Industrial

\footnotetext{
${ }^{21}$ Davidson, Two Models of Welfare : The Origins and Development of the Welfare State in Sweden and New Zealand, 1888-1988, 189.

${ }^{22}$ Henry Milner and Eskil Wadensjo, eds., Gosta Rehn, the Swedish Model and Labour Market

Policies: International and National Perspectives (Ashgate Publishing, June 2001). Chapter 1

23 Ibid.

${ }^{24}$ Ibid.

${ }^{25} \mathrm{P} 8$

${ }^{26} \mathrm{P} 8$

${ }^{27}$ Pontusson Labor Markets, Production Strategies, and Wage Bargaining Institutions p 226

${ }^{28}$ Fritz W Scharpf and Vivien Schmidt, eds., Sweden \& Denmark: Defending the Welfare State in Welfare and Work in the Open Economy (Oxford: Oxford University Press, 2000).
} 
Agreement of 1997 and the establishment of the National Mediation Office. Institutional resistance to 'substantive' change has allowed Sweden's unique industrial model to persist. ${ }^{29}$ Importantly, although there was adjustment in the institutional framework, the 'outcomes' and 'objectives' of the Swedish model remained largely unchanged. This new form of labour relations has maintained wage restraint and wage solidarity in Sweden. There has been a rise in inequality, but this has been marginal: Sweden is among the countries with the lowest wage distributions in the world. The core elements of the Swedish Labour model have remained intact and in some cases have been strengthened. ${ }^{30}$

Thus, core features can be attributed to the Swedish model of industrial relations. Those underlying features are the Rehn-Meidner model combined with a 'centralised' form of wage bargaining. They are:

(1) strong social partners and high levels of unionisation;

(2) political parties that do not deal with labour market issues;

(3) wage formation which is decided by the social partners; and

(4) the right to strike.

There are various 'means' to accomplish this, such as active labour market policies (ALMP) and public employment. The 'ends' of the model are: high aggregate wages; wage restraint (low distribution between wage earners and employers); wage solidarity (low distribution of income among wage earners); and strong worker protection.

While the Swedish model of industrial relations has been questioned in light of the ECJ ruling, its legal basis is where the main tension is identified. The next section will discuss Swedish law relevant to the case.

\subsection{SWEDISH LAW}

The constitutionally guaranteed right to industrial action is crucial to Swedish law. Constitutionally, all groups including trade unions and employer/employee

\footnotetext{
${ }^{29}$ Pontusson Labor Markets, Production Strategies, and Wage Bargaining Institutions p 226

${ }^{30}$ Ibid. p 225
} 
associations can take industrial action. ${ }^{31}$ Provisions, however, exist to limit the right to industrial action under certain conditions. It cannot be taken when a 'peace obligation' exists, in the form of a collective agreement, between the two parties. As a result, it is illegal to take industrial action to alter an existing collective agreement (including a collective agreement between foreign parties).

The Swedish government, however, has limited this restriction by the law of Lex Britannia. The law of Lex Britannia states that if temporary activities are undertaken (typically by posted workers) industrial action is permitted. In particular, this law has made it unlawful to take industrial action against those involved in a collective agreement only if it relates to conditions of work that have a strong connection to the Swedish labour market. The activity of posted workers is not considered to be strongly connected to the Swedish labour market. ${ }^{32}$

Thus, industrial action is classified by the Swedish constitution as a fundamental right to citizens, unless it infringes upon a collective agreement which has a strong connection to the Swedish labour market. The company Laval was only undertaking temporary work (with weak connection to the Swedish labour market) in Vaxholm, thereby giving Swedish labour unions a right to strike under Swedish law.

Lex Brittania is located in the 1976 Act on Co-determination at Work (MBL). This legislation deals with questions that arise from the relationship between employers and employees. This covers the areas such as: right of association, right of negotiation, duty of negotiation, exchange of information, obligation to maintain industrial peace, notification, and damages. ${ }^{33}$ Another important piece of legislation in the Swedish labour market is the 1999 Foreign Posting of Employees Act (utstationeringslagen). This Act outlines the provisions that were made in order to make Swedish industrial relations compliant with the 1996 Posting of Workers Directive. The Foreign Posting of Employees Act makes no mention of minimum wages for posted workers because it was initially believed to be covered by the Lex Brittania clause in the MBL. What the Act does include, however, are areas such as: annual leave, parental leave, and

\footnotetext{
${ }^{31}$ Eklund, "The Laval Case," 203.

${ }^{32}$ Ibid.

${ }^{33}$ 1976:580, "Employment (Co-Determination in the Workplace) Act," (Ministry of Employment, 1976), Swedish Trade Union Confederation [LO], "The Act on Co-Determination at Work," http://www.lo.se/home/lo/home.nsf/unidView/79A09A1894097983C1256E510038D65B.
} 
discrimination. ${ }^{34}$ With the relevant parts of the Swedish labour market model and Swedish law outlined, the next section will discuss European employment policy.

\subsection{EUROPEAN EMPLOYMENT POLICY}

The European Union consists of countries with diverse national models of industrial relations. Within this range of national models, Sweden can be characterised as an 'outlier', perhaps alongside with Denmark. Specifically, out of the 27 EU member states, 25 have either at least some form of legislated minimum wages or universal declaration of collective agreements. The differences between Sweden and the EU average are illustrated in Table 3.4 which indicates trade union density, workplace representation, collective bargaining coverage, degree of bargaining centralisation, and strike activity index. It is important to note that all member states have some anomaly in their industrial relations system, and Sweden is not necessarily the only outlier.

Table 3.2. Sweden and EU25 Industrial Relation Indicators

\begin{tabular}{l|ll}
\hline & Sweden(\%) & EU25(\%) \\
\hline Trade Union Density & 77 & 25 \\
Workplace Representation & 86 & 53 \\
Collective Bargaining Coverage & 92 & 66 \\
Degree of Bargaining Centralisation & 56 & 34 \\
Strike Activity Index & 3 & 9 \\
\hline
\end{tabular}

Source: European Industrial Relations Observatory

While the process of Europeanisation has an impact on national models, there is no European model of industrial relations per se. It is more useful is to define European employment policy, so as to discuss its effect on national models of labour relations.

The European employment policy is centred on three core areas:

1. combination of the 'Community method' and EU regulatory model;

2. social dialogue and law via collective agreement; and

3. the European Employment Strategy (EES) and the Open Method of Coordination (OMC).

\footnotetext{
${ }^{34}$ 1999:678, "Foreign Posting of Employees Act," (Ministry of Employment 1999).
} 
Commentators have observed that employment policy in the European Union has often been closely linked to social policy development. ${ }^{35}$ It has been most successful at producing 'negative' integration or 'harmonising downwards'; in other words, European employment policy has liberalised aspects of European labour markets. ${ }^{36}$ It has been less successful at 'positive' integration - building institutions - in particular, creating a 'social Europe'. This is particularly the case as employment policy has largely been under 'unanimity' voting, rather than 'qualified majority voting' (QMV) in area of market deregulation. However, there has been an ongoing dispute over the ability to deliver a coherent policy plan as tools for delivery has been experimental and have changed over time.

An important aspect of area one, the combined community method and EU regulatory model, is its focus on legislation and legalistic modes. This is in contrast to Sweden which has relied upon co-operation between the social partners. ${ }^{37}$ Area two, social dialogue and law via collective agreement, moved this initial focus, however, it retained a legalistic manner. Here, the legislative proposals were moved to the method of law through collective agreement. ${ }^{38}$ Area three, in contrast has used 'soft' mechanisms of labour co-ordination, through the use of the Open Method of Coordination (OMC) and the European Employment Strategy (EES). Here, states are not legally bound to any instruction, rather monitoring by member states aims to encourage compliance. ${ }^{39}$ The EES aims to increase cooperation among actors, co-ordination of national employment policies, and convergence of labour market outcomes. ${ }^{40}$

Another important point is that overarching policies of the EC aim to create a free market of labour, capital, and technology. This suggests there has in general been a bias toward the neo-liberal approach, where labour and moves freely with minimal barriers from government. And where intervention is permitted, this is generally reserved by the state giving it a monopoly in the regulation of the labour market.

In summary, the three core aspects of European employment policy can be characterised as follows. First, it aims to co-ordinate diverse labour markets under a

\footnotetext{
${ }^{35}$ Helen Wallace, William Wallace, and Mark A. Pollack, eds., Policy-Making in the European Union (Oxford ; New York: Oxford University Press, 2005), 280.

${ }^{36}$ Ibid.

${ }^{37}$ Ibid., 301.

${ }^{38}$ Ibid.

${ }^{39}$ Ibid.

${ }^{40}$ Ibid., 302.
} 
single umbrella. Second, European employment policy has a legalistic nature. Where it regulates the labour market, it does so using legislation through state implementation. And third, it has a liberal character and seeks to create a single market for labour (alongside capital, services, and technology) within the EU with minimal obstacles. From here, the next section will discuss the relevant EC law and how it is applicable to the events of the Laval dispute.

\subsection{EC LAW}

EC law will be discussed in two main themes: the Posting of Workers Directive, followed by the EC Treaty. EC law provides an important background to the Laval case as it explains why the Swedish industrial relations model has come into question by the ECJ.

The Posting of Workers Directive (96/71/EC) was established to provide a legal framework in which EU countries can determine minimum conditions for posted workers. Posted workers are temporary labour sent to another member state for a limited period of time (usually a maximum of 4 weeks). ${ }^{41}$ The Directive was first proposed in 1991 and only finalised in 1996 after extensive debate between member countries over its content. ${ }^{42}$ The core purpose of the Posting of Workers Directive is to ensure minimum standards and equality of treatment in the free movement of services and competition. ${ }^{43}$ Many problems have been associated with the transposing of the directive into member-state law, particularly in ensuring it is consistent with EC law. ${ }^{44}$

The mechanism used in Sweden to ensure minimum standards for posted workers was found to be in conflict with the EC Treaty. The tension stems from the breach of four core articles of the EC Treaty: Article 12, Article 49, Article 50, and Article 234.

An important aspect of the EC treaty is the principle against discrimination on the grounds of nationality:

\footnotetext{
${ }^{41}$ Jan Cremers, Jon Erik Dølvik, and Gerhard Bosch, "Posting of Workers in the Single Market: Attempts to Prevent Social Dumping and Regime Competition in the European Union," Industrial Relations Journal 38 no. 6 (2007): 524-25.

${ }^{42}$ Anonymous, "European Communities: Posted Workers Draft Strengthened," European Industrial Relations Review 236 (Sept 1993): 22-25.; Anonymous, "No Progress on Posted Workers," European Industrial Relations Review 255 (April 1995): 2.

${ }^{43}$ Cremers, Dølvik, and Bosch, "Posting of Workers in the Single Market: Attempts to Prevent Social Dumping and Regime Competition in the European Union," 527-28.

44 Ibid.
} 


\section{PART ONE PRINCIPLES Article 12}

Within the scope of application of this Treaty, and without prejudice to any special provisions contained therein, any discrimination on grounds of nationality shall be prohibited.

The Council, acting in accordance with the procedure referred to in Article 251, may adopt rules designed to prohibit such discrimination.

As discussed in the Swedish law section, Lex Brittania states that the rules for industrial action depend on whether the collective agreement has a strong link to the Swedish labour market or not. In other words, different rules apply depending on the 'nationality' of a collective agreement. This is 'discrimination' under prohibited by Article 12.

Another important feature of the EC treaty is the article of the free movement of services:

\section{CHAPTER 3 SERVICES Article 49}

Within the framework of the provisions set out below, restrictions on freedom to provide services within the Community shall be prohibited in respect of nationals of Member States who are established in a State of the Community other than that of the person for whom the services are intended.

The Council may, acting by a qualified majority on a proposal from the Commission, extend the provisions of the Chapter to nationals of a third country who provide services and who are established within the Community.

In other words, the article prohibits any organization or actor from restricting the freedom of a company in one member state to provide services in another. This suggests that Swedish trade unions cannot prevent Laval from providing services in Sweden. Article 49 contradicts the Swedish constitution that gives unions the right to undertake industrial action against employers with collective agreements of little connection to the Swedish labour market. As a result this tension is a highly contentious issue. Lex Brittania aims to prevent the 'unfair' competition posed by foreign labour subject to few minimum standards. From an EU perspective, however, prevention of unfair competition in this way restricts the free movement of services. 
While Article 49 limits actors (such as trade unions) from restricting the freedom of services, Article 50 suggests that the state can impose some minimum standards on foreign workers:

\section{CHAPTER 3 SERVICES Article 50}

Services shall be considered to be "services" within the meaning of this Treaty where they are normally provided for remuneration, in so far as they are not governed by the provisions relating to freedom of movement for goods, capital and persons.

"Services" shall in particular include:

(a) activities of an industrial character;

(b) activities of a commercial character;

(c) activities of craftsmen;

(d) activities of the professions.

Without prejudice to the provisions of the chapter relating to the right of establishment, the person providing a service may, in order to do so, temporarily pursue his activity in the State where the service is provided, under the same conditions as are imposed by that State on its own nationals.

In other words, minimum standards may be enforced by the state but must be the same as what is imposed on its own nationals. The important distinction to note is that while Article 49 limits restrictions on the freedom of services, Article 50 gives the state - not mentioning the social actors - some power to impose minimum condition.

Article 234 proves important as it states that interpretation of the EC laws ultimately falls on the ECJ:

\section{SECTION 4 THE COURT OF JUSTICE Article 234}

The Court of Justice shall have jurisdiction to give a preliminary ruling concerning:

(a) the interpretation of this Treaty;

(b) the validity and interpretation of acts of the institutions of the Community and of the ECB;

(c) the interpretation of the statutes of bodies established by an act of the Council, where those statutes so provide. 
The ECJ has the discretion to interpret the meaning of the treaty, and therefore is ultimately accountable for deciding whether EC or national legislation will dominate in the case of a dispute. Furthermore, the ECJ has discretion to protect the 'public interest' where workers' rights will be marginalised (for example to stop 'social dumping'). ${ }^{45}$ If the ECJ enforces its discretion to protect the public interest it may allow national legislation to override EC law where it will harm the local population.

Thus, the EC treaty prohibits any organization from restricting a company's freedom to provide goods and services to another EC state; it further encourages the free movement of labour, and prevents discrimination on the grounds of nationality. An important aspect of the EC treaty, however, is the discretion given to the ECJ to interpret how these prohibitions will be applied whey they conflict with national legislation.

The Swedish model and Swedish law on the one hand, and EU employment law and EC law on the other, has been the core conflict of the Laval case. With this outlined, the next section will discuss and define the ECJ ruling. This is a prerequisite for understanding and explaining the positions of the social partners that will be examined in the following chapter.

\subsection{ECJ RULING}

The ECJ ruling has been interpreted in varying ways. On a basic level, these different interpretations may contribute to explaining the importance of this case. In particular they may demonstrate why the case has roused such emotional sentiment and stimulated strong public debate within and outside of Sweden. As with many important legal rulings, the complex and legalistic nature of the Laval judgement leads to some difficulty in interpretation, particularly when assessing its broader implications. Among certain groups, particularly legal circles, the ruling has been received with little animosity and general clarity in its provisions. Others groups however, such as political parties and social partners, have expressed a degree of outrage highlighting perceived contradictions and violations embedded in the judgement. ${ }^{46}$

\footnotetext{
${ }^{45}$ Eklund, "The Laval Case," 205.

${ }^{46}$ Swedish Parliament, "The Current Debate: The Rights of Trade Unions in the Eu," (Parliamentary Protocol, 2008, May 12). Swedish Parliament, "Response to Interpellations
} 
The following section will explain how the European Court of Justice ruled in the Laval Case (C-341/05). Two core areas of the ruling will be expanded upon. First, this section will explain why the methods used by the Swedish trade unions, with the stated objective of prevent social dumping, were deemed illegitimate. Second, it will further explain the ruling concerning Lex Britannia.

The first issue is the compatibility of the Posted Workers Directive with the industrial action used by the Swedish trade unions during the Vaxholm dispute. The ruling on this issue is explicit. It specifically states that the PWD does not allow a trade union to take industrial action to force foreign companies to sign a collective agreement. ${ }^{47}$ The emphasis here is on the nationality of the firm. While collective action cannot be used for this purpose, other options are available under the PWD.

The ECJ ruled that Sweden had not used the full extent of the options available to it to protect itself against social dumping. The court stated that there is room for protection against social dumping in Article 3(1) (by law, regulation or administrative provision, or by universally declared collective agreements) and Article 3(8) (alternative options outside universally declared collective agreements). Highlighted in the Committee Terms of Reference, the options available for use by Sweden in Article 3(8) are by means of collective agreement which are generally applicable or concluded by the most representative employers and labour organisations in an area. ${ }^{48}$ This is supported by the paragraph 68 of the legal judgement which states:

It must be noted, in this respect, that since the purpose of Directive $96 / 71$ is not to harmonise systems for establishing terms and conditions of employment in the Member States, the latter are free to choose a system at the national level which is not expressly mentioned among those provided for in that directive, provided that it does not hinder the provision of services between member states. ${ }^{49}$ [Italics added by author]

2007/08: 624, 560, 561, 562, 563 and 582 on Issues on the Occasion of Laval and Rüffert Cases," (Parliamentary Protocol, 2008, May 13), Marianne Björklund, "Lavalmål Väcker Heta Känslor (Laval Case Arouses Hot Feelings)," Dagens Nyheter 2008, April 23, Christin Johansson, "Eu-Hot Mot Kollektivavtal Nonchaleras Av Regeringen (the Eu Threat to Collective Agreements Ignored by Government) " Dagens Nyheter 2008, August 18.

${ }^{47}$ European Court of Justice [ECJ], "Judgement of the Court (Grand Chamber)," ed. European Court of Justice (2007), paragraph 121.

${ }^{48}$ An area may be defined as a geographical area or a profession or industry in the first instance.

In the second instance it refers to the national territory.

${ }^{49}$ [ECJ], "Judgement of the Court (Grand Chamber)," paragraph 68. 
In other words, the ECJ does not prohibit states from protecting themselves against social dumping outside of legislative means. Nor does it rule that industrial action cannot be undertaken by the social partners as a tool to prevent wage dumping. Instead, the judgement bars unions from using industrial action to force companies to sign agreements that are not transparent (clear terms and conditions). This lack of transparency and predictability is where the incompatibility has arisen. As stated in the ruling, Sweden is free to find a mechanism so long as it is transparent, predictable and does not impede the free movement of services.

A further implication of the ruling is that a state cannot demand from foreign posted workers more than what it outlined as the 'hard core' of the directive in Article 3(1). ${ }^{50}$ The judges ruled that public policy, in Article 3(10), cannot be used in this case to extend the 'hard core' of the PWD because trade unions are not 'bodies governed by public law'. 51

A further aspect of the ruling is identified between paragraphs 95 and 110 of the original judgement by the court. These too have been identified in the Terms of Reference to the Claes Stråth investigation. ${ }^{52}$ The ruling makes specific reference to whether or not collective action is a fundamental right that can override the 'freedom of services'. The judgement states that industrial action is considered a fundamental right which can override the freedom of services (Article 49), if it is for the purpose of public interest. ${ }^{53}$ This classifies the protection of domestic workers from social dumping as being in the 'public interest'. 54

In the Laval case, however, the court ruled that the unions were asking the foreign company to sign a collective agreement which went far beyond the prevention of social dumping. ${ }^{55}$ The conditions regarding minimum pay were not transparent and subsequently could not be used as a justification of the public interest criteria. ${ }^{56}$ In

\footnotetext{
${ }^{50}$ This is highlighted in the Committee Terms of Reference.

${ }^{51}$ Ministry of Employment, "Committee Terms of Reference " (Consequences of action in response to the Laval judgment; decision at a Government meeting on 10 April 2008), 3.

${ }^{52}$ Ibid., 4.

${ }^{53}$ [ECJ], "Judgement of the Court (Grand Chamber)," paragraph 103.

${ }^{54}$ Employment, "Committee Terms of Reference ", 4.

55 [ECJ], "Judgement of the Court (Grand Chamber)," paragraphs 108-10.

${ }^{56}$ Ibid., paragraph 110.
} 
other words, the demands made on the foreign company went beyond the 'hard core' of Article 3(1) of the PWD.

The second issue ruled by the ECJ concerns the right to undertake industrial action. Particularly it assesses whether a collective agreement can be enforced by a trade union (in the form of industrial action). ${ }^{57}$ In the ruling, the court prohibits unions using industrial action as a tool to enforce national laws. ${ }^{58}$

Specifically, the judgement decided that Lex Britannia discriminates on the basis of nationality rather than the content of a collective agreement. ${ }^{59}$ Lex Britannia rules that any obligations which are decided in a foreign member country via collective agreement are illegitimate in Sweden. In other words, this law defines all foreign collective agreements which are formulated outside of Sweden null and void. ${ }^{60}$ While this may have the effect of impeding social dumping, it goes beyond, by discriminating against all foreign collective agreements irrespective of its content.

For the purposes of the study, there are four key points to the ECJ ruling: first, the PWD does not allow trade unions to force foreign companies to sign a collective agreement. Sweden had not used all of the options available to it to protect itself from social dumping. Second, demands cannot be made beyond the 'hard core' of the PWD. The Swedish unions' collective agreements were found to be insufficiently transparent to meet the 'hard core' of the PWD. Third, the Laval case did not meet the criteria of issues of public policy, public health, or public security for the 'hard core' to be extended. In this case, therefore, industrial action did not qualify a fundamental right that would override the freedom to provide services. Fourth, the ECJ found that Lex Britannia distinguishes on the basis of the 'nationality' of a collective agreement, thereby violating EC non-discrimination rules.

The courts findings against the Swedish model resulted from complex interplay between events, the Posting of Workers Directive (96/71/EC) and the EC treaty. The justification has been confined to a core collection of articles: Articles 3(1), 3(8), and 3(10) of the Posted Workers Directive; and Articles 12 EC, 49 EC, 50 EC, and 234 EC of the EC treaty.

\footnotetext{
${ }^{57}$ Ibid., paragraph 112.

${ }^{58}$ Ibid., paragraph 121.

${ }^{59}$ Employment, "Committee Terms of Reference ", 4.

${ }^{60}$ [ECJ], "Judgement of the Court (Grand Chamber)," paragraph 113.
} 
This ruling brings to fore the role of unforeseen consequences. The Posting of Workers Directive was written and agreed upon in a context in which such a dispute had not yet been experienced. When it was written in 1996, the Eastern Enlargement was not necessarily forecasted. As a result the issues associated with widening integration (as distinct from deepening integration) could not have been addressed in it. $^{61}$

The ruling highlights some of the claims made on the Swedish side, particularly by the social partners, that there is a deficit of knowledge within the European Union regarding the complexity of the Swedish system of industrial relations. In short, a great deal of work would be needed to make all collective agreements in Sweden 'transparent'. ${ }^{62}$ Collective agreements are often extensive documents that merely have a set of guidelines, rather than the raw numerical values required to make them transparent. This is despite claims made at the European level that the Swedish model and the Posted Workers Directive are in fact compatible. This may provide an explanation of why Sweden did not make any references to minimum wages in the Swedish Foreign Posting of Employees Act, 1999: the system of Lex Britannia was believed by some to be sufficient.

The legal complexities surrounding the ruling make it difficult for some actors (such as smaller organisations or individuals) to articulate well regarded positions on it. This tends to restrict official debate over the ruling to elites and peak-level organisations

As a result, there is some confusion by actors over what the ECJ has in ruled in this particular case. Actors have different ideas of what the decision said, and as a result prescribe different remedies. This is further compounded by the complex debate over potential options for remedying the issue, and their consequences. The next section will provide background on the three main framings of the ECJ.

\footnotetext{
${ }^{61}$ The 'writing was on the wall', however, after the 1993 Copenhagen Declaration.

${ }^{62}$ Official 2A, "Interview " (Swedish Agency for Government Employers [SAGE], 2008, October 14), Claes Stråth, "Interview," (National Mediation Office, 2008, October 30).
} 


\subsection{DIFFERENT FRAMES IN WHICH TO VIEW THE ECJ RULING}

At this point, it is useful to distinguish between different actors' views on the ECJ ruling. Before doing so, it is important to note that the above discussion is somewhat simplified.

It is difficult to find a single authoritative interpretation of the ruling as it is not singular, but rather a collection of interrelated judgements. Due to the fragmented nature of the ruling, different actors may emphasise different parts of it depending on their interests. Different interpretations may also result intentionally, to make a particular argument, or unintentionally due to a genuine misinterpretation. The following section, will address the different ways in which the ECJ ruling can be viewed.

To begin, this thesis makes no claim that this typology exhausts all frames through which this ruling can be viewed. Nor does it claim that these are the exact ways in which the actors view the ruling. Rather, it sets out three broad perspectives that illustrate the diversity of actors' perspectives. Furthermore, it is important to clarify that the perceptions and frames of the ruling change over time, particularly as actors invest more resources toward uncovering the nuances of the ruling. Therefore, while the views of some actors have remained largely unchanged over the entire duration from the judgement in December 2007, others have shifted to differing degrees. To illustrate this, the following section will illustrate three frames that will be used in this study: (1) simplified; (2) narrow; and (3) wide.

The simplified frame is one often utilised by individuals and actors with only passing concern, or those who do not possess a large degree of information about the issue. This view can be summarised as follows:

The ECJ ruling states that foreign companies can now come to Sweden and work under home conditions.

This frame places focus on the immediate outcome of the ruling. While not exhaustive, does hold some basic explanatory merit, although it is factually incorrect in some ways. It does, however, illustrate the immediate effect of the ruling, and has been 
used by actors such as the media, politicians and political parties, and in public discussion. ${ }^{63}$

A second frame, narrow, pays greater attention to the specific components of the judgements that were made by the ECJ. This view can be summarised as follows:

The ECJ ruling states that a country cannot use industrial action to prevent socialdumping (and to keep out low-wage firms). They are, however, able to use legislated minimum wages, or extension of collective agreements (erga-omnes) to combat socialdumping.

The third frame, wide, reads a broader scope into the ECJ judgement and allows a greater degree of room to be made at the national level while still being consistent with EC law. This view can be summarised as follows:

The ECJ ruling states that a country cannot use industrial action, in the same manner as during the Laval dispute, to prevent social-dumping (and to keep out low-wage firms). There may be room in Article 3.8 of the PWD to find a solution in the autonomous collective agreement model. The options of legislated minimum wages, or extension of collective agreements (erga-omnes) to combat social-dumping have not been ruled out by the ECJ either.

The wide frame, like the narrow frame, views legislated minimum wages and the extension of collective agreements as legitimate mechanisms to combat social dumping. It has the view, however, that the Posted Workers Directive allow Sweden to find solutions that will impose minimal change on the Swedish model of industrial relations.

Most of the social partners investigated in this thesis employ either a wide or narrow frame. Actors that hold a simplified frame continue to exist: in particular, politicians and political parties have utilised this frame when communicating ideas and

\footnotetext{
63 Swedish Parliament, "Response to Interpellation 2007/08:483 on the Investigation in Response to the Laval Case," (Parliamentary Protocol, 2008, March 10). Anonymous, "Sweden Disappointed by Eu Ruling," The Local 2007, Dec 18 , Anonymous, "'Free-for-All' to Follow Eu Ruling," The Local 2007, Dec 27
} 
proposals concerning the Laval ruling to the public, media, and political representatives.

The next section will define the four core options that are found in the discussions between the social partners. Defining these options is necessary in order to understand what the social partners want for the labour relations in Sweden.

\subsection{DEFINITIONS: LEGISLATED MINIMUM WAGE, ERGA OMNES, EXTENSION MODEL, AND STATUS QUO}

There are a range of options being considered by actors in Sweden on how to respond to the ECJ ruling. The options available to the social partners and actors within the Swedish model are generally restricted to two spheres: first, changes at the European level; and second, changes at the national level. Options for change at the European level include defiance of the ECJ ruling and exit from the EU. Exit from the EU, however, has not been advocated by any significant actors. Other options have had some support, although they tend to be marginalised within large actors. The spectrum for change at the European level is outlined below:
(1) defiance of ECJ and exit from the EU;
(2) re-working of the Posted Workers Directive; or
(3) linking of the Laval case to the Lisbon treaty ratification.

It is the options for change at the national level, however, that have received the greatest attention from the social partners. The changes proposed on this level are:

\footnotetext{
(4) legislated minimum wage;

(4) erga omnes;

(5) extension model; or

(6) status-quo (liberalisation for foreign workers, and the Swedish model for Swedish workers).
} 
The term 'minimum wage' is widely used and is subject to competing interpretations. In addition, there are many institutional mechanisms that can be used to achieve minimum conditions. Of particular concern to this study is that different mechanisms have varying degrees of state involvement; this is highly relevant when assessing change to the Swedish model. As discussed earlier in this chapter, the 'Swedish model' of industrial relation has wage setting practices that exclude the state. Thus, an increase in state involvement would be a substantial change to the model.

This section will define the main mechanisms for wage setting, particularly those options which have been discussed by the social partners in the context of the Laval case. Four potential mechanisms will be discussed. The first two, legislated minimum wage model and the extension of collective agreement model, are outlined in Article 3(1) of the Posted Workers Directive. The third category, the Autonomous Collective Agreement Model, is the most ambiguous and has attracted the greatest level of debate; it draws upon Article 3(8) of the Posted Workers Directive. The fourth option to be outlined is the Status-quo option. Within each of the four main types, a great deal of diversity exists. This section presents a sample of this diversity, however, does not claim to comprise an exhaustive list. ${ }^{64}$

\section{Legislated Minimum Wage}

The legislated minimum wage model is in widespread use as a regulatory mechanism throughout Anglo-Saxon countries, such as New Zealand, Australia, Canada, US, and UK. However, a great deal of diversity exists between these countries, particularly regarding the following: obligations for consultation; review periods; and which actors can make recommendations. ${ }^{65}$

Typically, in the above countries, legislated minimum wages are a single minimum floor. They do not, however, necessarily take this form. A range of minimum wages may exist within a single country depending on factors such as occupation, industry, age, region, length of time in a company, and full-time or part-time status.

\footnotetext{
${ }^{64}$ For a more comprehensive overview see: Franz Traxler and Martin Behrens, "Collective Bargaining Coverage and Extension Procedures," European Industrial Relations Online (EIRO) http://www.eurofound.europa.eu/eiro/2002/12/study/tn0212102s.htm. François Eyraud, The Fundamentals of Minimum Wage Fixing (Geneva : International Labour Office, 2005).

${ }^{65}$ Eyraud, The Fundamentals of Minimum Wage Fixing 16-17.
} 
Three broad methods of wage setting are identified: unilateral government decision; government decision in consultation with some or all of the social partners; and recommendation to the government from a specialised body. ${ }^{66}$

Each method has different ramifications for the level and number of minimum wages that may be set in a particular country. Each of these factors will in turn be influenced to a different degree by politicisation (minimum wages as an electoral issue, or being subject to lobbying) and the institutional constraints involved in passing new legislation.

The key feature, however, of all legislated minimum wage processes, is that minimum standards are set by the government. ${ }^{67}$ This may be in the form of changes coming directly from the government, or from an appointed committee delegated with that responsibility. ${ }^{68}$ The second option of extending collective agreements typically involves even less state involvement, albeit different degrees exist depending on the variant used.

Universal Declaration of Collective Agreements or Erga Omnes (Allmangiltigförklaring)

Extension procedures for collective agreements can be conceived of in two ways: narrow and broad. The narrow use of universal declaration of collective agreements is a common extension practice widely used among EU member states. This mechanism legally makes applicable collective agreements to all employers and employees that do not belong to a respective trade union or employers association. ${ }^{69}$ This generally occurs within a single sector, and is useful in countries that have low levels of union coverage.

A wide variety of procedures exist to extend a collective agreement. In countries such as Austria and Finland, the social partners determine the conditions in a collective

\footnotetext{
${ }^{66}$ Ibid., 14-15.

${ }^{67}$ Ibid., 16.

${ }^{68}$ The variation in who initiates and approves minimum wages gives an indication of the level of state involvement. Thus, legislated minimum wage setting might have a high level of state involvement. An example of this is the US where it is a unilateral decision and there is no obligation to consult the social partners. In contrast, Japan is an example of a legislated minimum wage with low state involvement. Here, the government can approve the minimum wage rate only after a recommendation by a specialised body.

${ }^{69}$ Traxler and Behrens, "Collective Bargaining Coverage and Extension Procedures."
} 
agreement and extension occurs automatically. ${ }^{70}$ In others, extension may come at the request of the social partners. ${ }^{71}$ In other scenarios, a collective agreement may only be extended at the request of the government. ${ }^{72}$ In many cases countries use a combination of the above examples.

In addition to this there are often minimum criteria that need to be met before a collective agreement can be extended, whether automatically or from the initiative of a legitimate party. In other cases, there are no minimum conditions and extension occurs automatically. A common criteria, however, is that the collective agreement to be extended needs to be representative within a specific sector. In many countries, such as Greece and Germany, the collective agreement should cover at least 50\% of the respective sector prior to extension. ${ }^{73}$ The most common extension procedure is to a particular sector, however, it can also be applied across a geographical region.

Another nuance with regard to the erga omnes of collective agreements is what parts of the collective agreements are extended. In many examples it is the entire collective agreement, but this does not need to be the case. In the case of Denmark, only the areas with specific regard to EU directive are extended. ${ }^{74}$ Ireland uses an approach where the only clauses extended are those that regard minimum wages and working conditions. ${ }^{75}$ This is of relevance to Sweden, and it is likely this type of application would be followed rather than a system that extends the whole collective agreement.

Thus, while a degree of diversity exists within the universal declaration of collective agreement model, its core features are rather explicit. It involves extending all or part of an existing agreement across a particular sector or region given certain criteria are met.

These variants of both the legislated minimum wage and the universal declaration of collective agreement mechanisms are consistent with EC law and are supported by Article 3(1) of the Posting of Workers Directive. Article 3(8) allows for a system that

\footnotetext{
70 Ibid.

71 Ibid.

${ }^{72}$ Ibid.

73 Ibid.

74 Ibid.

75 Ibid.
} 
is not explicitly outlined in Article 3(1), so long as the provision of services between member states is not impeded. ${ }^{76}$

\section{Extension Model (Autonomous Collective Agreements)}

The definitions of the legislated minimum wage model, and the system of universal declaration are clearer than those of the 'extension model'. The third group of options arise primarily from Article 3(8). Due to the predominance of universal declaration of collective agreement and legislated minimum wages being used throughout Europe, this 'third way' is less developed and, as a result, there is more uncertainty concerning its definition. It was originally created for the use by countries Denmark, Sweden, and Italy - that did not have either of the first two mechanisms.

This section will outline two variants of this 'third way': the extension model; and its subset, the autonomous collective agreement model. The autonomous collective agreement model allocates wage setting to the social partners and excludes the state. Thus, it acts as a voluntary system where both sides of labour and capital bargain minimum wages which are set out in collective agreements. This system deviates the least from the 'Swedish Model' and in some respects, is only making small adjustments to ensure compatibility with EC law.

In the autonomous collective agreement model, trade unions can force firms to sign a collective agreement through the threat of industrial action. This mechanism to enforce minimum conditions is important for two reasons. Firstly, it is working outside of legislation to regulate minimum conditions for workers. The legislated minimum wage model and erga omnes principle both use law, and the creation of law on these cases lead to a rigidity in what are minimum conditions. The autonomous collective agreement model is more fluid, allowing minimum standards to be 'flexible' so long as agreement is reached between the employer and employee representatives.

Secondly, the autonomous collective agreement model does involve the state in the wage setting procedure. The conditions for workers are set purely on the basis of negotiation between the social partners. In other words, the mechanism to enforce

\footnotetext{
${ }^{76}$ [ECJ], "Judgement of the Court (Grand Chamber)," paragraph 121.
} 
minimum standards is not through 'state' power; rather it is through the use of industrial action by representative groups.

In order for the autonomous collective agreement model to be compatible with EC law, it must also meet a number of other characteristics. ${ }^{77}$ A trade union, in some cases, can force a company to sign a collective agreement. The criteria for permitting a union to do this, however, cannot be based on the nationality of the collective agreement. Trade unions can only make demands concerning minimum rates of pay, including overtime rate. ${ }^{78}$

In summary, the voluntary and collaborative features of the autonomous collective agreement model distinguish it from the first two models. The next model, the status-quo option, also contains some of its features, albeit with important differences.

\section{Status-quo}

The key distinction between the status-quo model and the autonomous collective agreement model is that unions are unable to use industrial action on foreign employers who enter Sweden on a foreign collective agreement. This includes situations where minimum standards in the foreign collective are below those generally acceptable in Sweden.

The status-quo option still allocates wage setting to the social partners, at the exclusion of the state. The distinction to the autonomous collective agreement model, however, is that wage setting is no longer a 'monopoly' between Swedish trade unions and employers. In the status-quo option, wage-setting processes are open to unions in all EU countries when concerning posted workers.

Swedish unions can still force firms to sign a collective agreement when no previous agreement is in place. If a firm has a collective agreement with a foreign trade union, however, no industrial action can be taken. Thus, the status-quo option suggests the same wage setting system for domestic workers. In terms of posted workers, however, a very new system of wage setting is introduced that is European wide.

\footnotetext{
${ }^{77}$ This is if the Laval ruling is framed in the 'wide' sense. See Section 3.5.

${ }^{78}$ This is also the case for legislated minimum wages and extension of collective agreements.
} 
Figure 3.1 provides a diagram for what each of the four wage setting models would mean for Swedish industrial relations. It includes a distinction between its impact on domestic workers, versus the impact on posted workers.

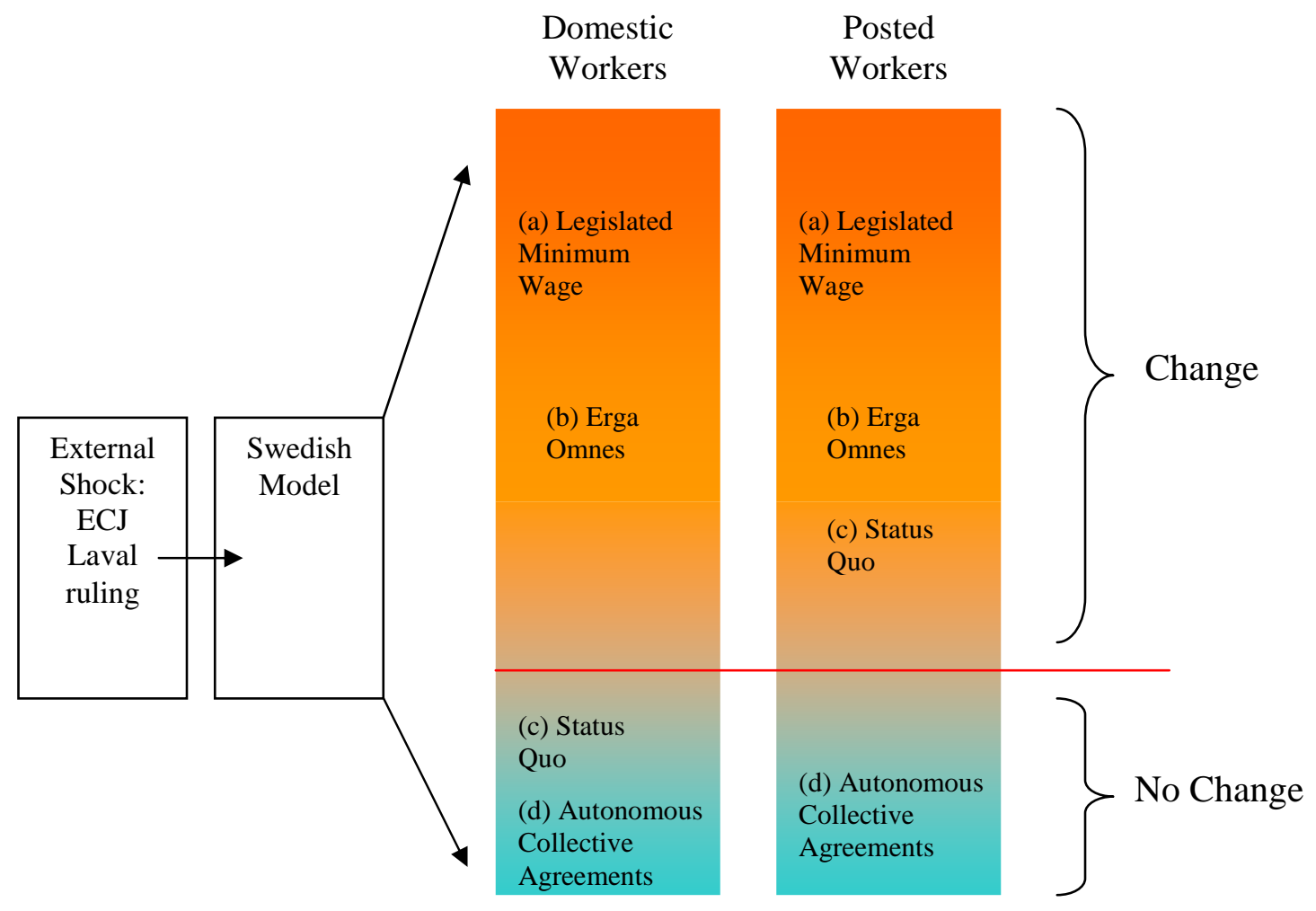

Figure 3.1 Four wage setting models

\subsection{CONCLUSION}

The aim of this chapter has been to provide the necessary contextual information and definitions so the remainder of the analysis can be undertaken. It outlined the details of the event and action taken by Swedish trade unions that stopped the firm Laval from using posted workers under foreign of collective agreement.

The dispute was the result of tension between the Swedish model and Swedish law on the one hand, and EU employment policy and EC law on the other. The chapter defined the main features of the 'Swedish model' to include: strong social partners and high levels of unionisation; political parties that do not deal with labour market issues; 
wage formation which is decided by the social partners; and the right to strike. The parts of Swedish law that underpinned this model were the constitutional right to industrial action, Lex Britannia, and the Foreign Posting of Employees Act). European employment policy aimed to co-ordinate labour markets, was legalistic, and had a liberal character. The core aspects of the EC law relevant to the Laval case were found in Articles 12, 49, 50, and 234 of the EC Treaty.

This background provides a framework under which the final European Court of Justice ruling can be understood. The chapter outlined core areas of the ruling. The ECJ ruled that trade unions cannot force foreign companies to sign a collective agreement. Furthermore, Swedish law has not yet fully used all the tools available. In addition, the collective agreements pushed by the trade unions were not sufficiently clear and as a result, the demands were unjustifiably made beyond the hard-core of the Posting of Worker Directive. Finally, the court ruled that Lex Britannia discriminated on the basis of nationality and did not meet the criteria for the hard core of the Posting of Workers Directive to be extended.

This ruling was not received and interpreted uniformly by all members of the Swedish social partners. Different actors took simplified, narrow, or wide views. The distinction between narrow and wide is important as the wide frame sees additional options as compatible with EC law. The narrow interpretation views these options as inconsistent with EC law, particular the autonomous model of collective agreements. The final part of the chapter defined the options considered important by the social partners.

With this contextual information in place, the next chapter will assess the competing tensions within the Swedish model in response to the ECJ ruling. It will look at what different actors (both labour and employers) want for the Swedish model, and illustrate the tensions that exist between them. From here the study will be able to determine whether what we observe is change or continuity. In particular, the study will be best able to determine which of the theories of institutional change (convergence, punctuated equilibrium, or incremental transformation) best explain the dynamics within the Swedish model in response to the ECJ ruling. 
[ECJ], European Court of Justice. "Judgement of the Court (Grand Chamber)." edited by European Court of Justice, 2007.

Eyraud, Francois. The Fundamentals of Minimum Wage Fixing Geneva : International Labour Office, 2005.

Traxler, Franz, and Martin Behrens. "Collective Bargaining Coverage and Extension Procedures." European Industrial Relations Online (EIRO) http://www.eurofound.europa.eu/eiro/2002/12/study/tn0212102s.htm 
Davidson, Alexander Two Models of Welfare : The Origins and Development of the Welfare State in Sweden and New Zealand, 1888-1988. Uppsala: Academiae Ubsaliensis, 1989.

EIRO. "Sweden Industrial Relations Profile." European Industrial Relations Observatory, http://www.eurofound.europa.eu/eiro/country/sweden.htm.

Elvander, Nils. " Two Labour Market Regimes in Sweden." Industrielle Beziehungen. 10, no. s (2003): 146-59.

Milner, Henry, and Eskil Wadensjo, eds. Gosta Rehn, the Swedish Model and Labour Market Policies: International and National Perspectives Ashgate Publishing, June 2001.

Pontusson, Jonas, and Peter Swenson. "Labor Markets, Production Strategies, and Wage Bargaining Institutions: The Swedish Employer Offensive in Comparative Perspective." Comparative Political Studies April no. 29 (1996): 223 - 50.

Rueda, David, and Jonas Pontussion. "Wage Inequality and Varieties of Capitalism." World Politics Baltimore: Apr 2000 Vol.52, Iss. 3; pg. 350 (2000).

Scharpf, Fritz W, and Vivien Schmidt, eds. Sweden \& Denmark: Defending the Welfare State in Welfare and Work in the Open Economy Oxford: Oxford University Press, 2000.

Swenson, Peter A. Capitalists against Markets : The Making of Labor Markets and Welfare States in the United States and Sweden: New York : Oxford University Press, 2002.

Swenson, Peter, and Jonas Pontusson. "The Swedish Employer Offensive against Centralized Wage Bargaining." In Unions, Employers, and Central Banks: Macroeconomic Coordination and Institutional Change in Social Market Economies edited by Torben Iversen, Jonas Pontusson and David Soskice: Cambridge University Press 2000.

Wallace, Helen, William Wallace, and Mark A. Pollack, eds. Policy-Making in the European Union. Oxford ; New York: Oxford University Press, 2005. 
[ECJ], European Court of Justice. "Judgement of the Court (Grand Chamber)." edited by European Court of Justice, 2007.

Employment, Ministry of. "Committee Terms of Reference ": Consequences of action in response to the Laval judgment; decision at a Government meeting on 10 April 2008. 
2A, Official. "Interview ": Swedish Agency for Government Employers [SAGE], 2008, October 14.

1976:580. "Employment (Co-Determination in the Workplace) Act." Ministry of Employment, 1976.

1999:678. "Foreign Posting of Employees Act." Ministry of Employment 1999.

[ECJ], European Court of Justice. "Judgement of the Court (Grand Chamber)." edited by European Court of Justice, 2007.

[LO], Swedish Trade Union Confederation. "The Act on Co-Determination at Work."

http://www.lo.se/home/lo/home.nsf/unidView/79A09A1894097983C125 6E510038D65B.

Ahlberg, Kerstin, Niklas Bruun, and Jonas Malmberg. "The Vaxholm Case from a Swedish and European Perspective." Transfer 12, no. 2 (2006): 155-66.

Anonymous. "European Communities: Posted Workers Draft Strengthened." European Industrial Relations Review 236 (Sept 1993).

_. "'Free-for-All' to Follow Eu Ruling." The Local 2007, Dec 27

—. "No Progress on Posted Workers." European Industrial Relations Review 255 (April 1995).

_. "Sweden Disappointed by Eu Ruling." The Local 2007, Dec 18

Björklund, Marianne. "Lavalmål Väcker Heta Känslor (Laval Case Arouses Hot Feelings)." Dagens Nyheter 2008, April 23.

Cremers, Jan, Jon Erik Dølvik, and Gerhard Bosch. "Posting of Workers in the Single Market: Attempts to Prevent Social Dumping and Regime Competition in the European Union." Industrial Relations Journal 38 no. 6 (2007): 524 - 41.

Davidson, Alexander Two Models of Welfare : The Origins and Development of the Welfare State in Sweden and New Zealand, 1888-1988. Uppsala: Academiae Ubsaliensis, 1989.

EIRO. "Sweden Industrial Relations Profile." European Industrial Relations Observatory, http://www.eurofound.europa.eu/eiro/country/sweden.htm.

Eklund, Ronnie. "The Laval Case." The Industrial Law Journal 35, no. 2 (2006).

Elvander, Nils. " Two Labour Market Regimes in Sweden." Industrielle Beziehungen. 10, no. s (2003): 146-59.

Employment, Ministry of. "Committee Terms of Reference ": Consequences of action in response to the Laval judgment; decision at a Government meeting on 10 April 2008.

Eyraud, Franc $\square$ ois. The Fundamentals of Minimum Wage Fixing Geneva : International Labour Office, 2005.

Gerschenkron, Alexander. Economic Backwardness in Historical Perspective. Cambridge: Belknap Press, 1962.

Johansson, Christin. "Eu-Hot Mot Kollektivavtal Nonchaleras Av Regeringen (the Eu Threat to Collective Agreements Ignored by Government) " Dagens Nyheter 2008, August 18.

Menz, Georg. "Re-Regulating the Single Market: National Varieties of Capitalism and Their Responses to Europeanization." Journal of European Public Policy 10:4 (2003): 532-55.

Milner, Henry, and Eskil Wadensjo, eds. Gosta Rehn, the Swedish Model and Labour Market Policies: International and National Perspectives Ashgate Publishing, June 2001. 
Parliament, Swedish. "The Current Debate: The Rights of Trade Unions in the Eu." Parliamentary Protocol, 2008, May 12.

. "Response to Interpellation 2007/08:483 on the Investigation in Response to the Laval Case." Parliamentary Protocol, 2008, March 10. . "Response to Interpellations 2007/08: 624, 560, 561, 562, 563 and 582 on Issues on the Occasion of Laval and Rüffert Cases." Parliamentary Protocol, 2008, May 13.

Pontusson, Jonas, and Peter Swenson. "Labor Markets, Production Strategies, and Wage Bargaining Institutions: The Swedish Employer Offensive in Comparative Perspective." Comparative Political Studies April no. 29 (1996): 223 - 50.

Reich, Norbert. "Free Movement V. Social Rights in an Enlarged Union: The Laval and Viking Cases before the European Court of Justice " German Law Journal 9, no. 2 (2008): 125-61.

Rueda, David, and Jonas Pontussion. "Wage Inequality and Varieties of Capitalism." World Politics Baltimore: Apr 2000 Vol.52, Iss. 3; pg. 350 (2000).

Scharpf, Fritz W, and Vivien Schmidt, eds. Sweden \& Denmark: Defending the Welfare State in Welfare and Work in the Open Economy Oxford: Oxford University Press, 2000.

Stråth, Claes. "Interview." National Mediation Office, 2008, October 30.

Swenson, Peter A. Capitalists against Markets : The Making of Labor Markets and Welfare States in the United States and Sweden: New York : Oxford University Press, 2002.

Swenson, Peter, and Jonas Pontusson. "The Swedish Employer Offensive against Centralized Wage Bargaining." In Unions, Employers, and Central Banks: Macroeconomic Coordination and Institutional Change in Social Market Economies edited by Torben Iversen, Jonas Pontusson and David Soskice: Cambridge University Press 2000.

Traxler, Franz, and Martin Behrens. "Collective Bargaining Coverage and Extension Procedures." European Industrial Relations Online (EIRO) http://www.eurofound.europa.eu/eiro/2002/12/study/tn0212102s.htm.

Wallace, Helen, William Wallace, and Mark A. Pollack, eds. Policy-Making in the European Union. Oxford ; New York: Oxford University Press, 2005. 


\section{Positions Taken by the Social Partners}

The preceding chapter provided the necessary background information in order for the remainder of the study to be undertaken. It outlined the 'Laval' dispute and assessed the perspectives of Swedish and European law. The ensuing ECJ ruling was defined, as well as the competing frames in which the ruling can be viewed. In addition the previous chapter defined the Swedish model of industrial relations and European employment policy. And for the purposes of this chapter, it presented an overview of the main positions that have been taken by the Swedish social partners.

From this starting point, this chapter will now assess the positions of the peaklevel social partners. These consist of the two main private and public sector employers associations: the Confederation of Swedish Enterprise and the Swedish Agency for Government Employers (SAGE). From a labour perspective, this section will discuss the positions of the three main trade union organisations: Swedish Trade Union Confederation (LO), Swedish Confederation of Professional Employees (TCO), and Swedish Confederation of Professional Associations (SACO). In addition to these peak level associations, affiliate members will also be included in the analysis where necessary. To maintain the anonymity of officials, interviewees will be referred to by a number and letter as outlined in Table 4.1 below.

In response to the ECJ ruling, the social partners have put forth different options for changing (or preserving) the Swedish model of industrial relations. Previous studies suggest that there are conflicting view points on these topics. Furthermore, competing explanations exist for how and why the tensions will arise. For example, employers could attempt to undermine labour unions, or act alongside the interests of unions to promote mutual interests. 
Table 4.1 Interview Representatives and Organisations

\begin{tabular}{|c|c|c|}
\hline Representative & Peak-level organisation & Affiliate Organisation \\
\hline Official 1A & $\begin{array}{l}\text { - Confederation of Swedish } \\
\text { Enterprise }\end{array}$ & \\
\hline Official 1B & & $\begin{array}{l}\text { - The Association of the } \\
\text { Swedish Engineering } \\
\text { Industries } \\
\text { (Teknikföretagen) }\end{array}$ \\
\hline Official 1C & & $\begin{array}{l}\text { Electrical Installer } \\
\text { Organization (EIO) }\end{array}$ \\
\hline Official 2A & $\begin{array}{l}\text { - Swedish Agency for } \\
\text { Government Employers } \\
\text { (SAGE) }\end{array}$ & \\
\hline Official 3A & $\begin{array}{l}\text { - Swedish Trade Union } \\
\text { Confederation (LO) }\end{array}$ & \\
\hline Official 3B & & $\begin{array}{l}\text { - Trade Union of } \\
\text { Commercial Employees } \\
\text { (Handels) }\end{array}$ \\
\hline Official 4A & $\begin{array}{l}\text { - Swedish Confederation of } \\
\text { Professional Employees } \\
\text { (TCO) }\end{array}$ & \\
\hline Official 5A & $\begin{array}{l}\text { - Swedish Confederation for } \\
\text { Professional Associations } \\
(\text { SACO })\end{array}$ & \\
\hline
\end{tabular}

This chapter will take a four fold approach and assess the views of the social partners on the main options: the legislated minimum wage model, the erga omnes model, the extension model (autonomous collective agreement), and the status-quo option. These competing options will affect the Swedish model in different ways and indicate what type of change is expected. As the previous chapter outlined the criteria for change, this section will illuminate the pressures for change within the model.

To begin, this chapter will briefly discuss the nature of the positions of the social partners, in particular how they have evolved over the course of events. Second, it will assess the legislated minimum wage option. This is the only model of the four not to be included in the Claes Stråth investigation. It will look at the competing arguments for and against a minimum wage. Third, this chapter will look at arguments for and against the erga omnes model, which is perhaps the most 'European' of all the options available. The fourth section of the chapter will discuss the views on the autonomous collective agreement model. This is the most widely agreed upon model, but it also the most controversial: particularly as to whether this option is actually possible, and whether it can be kept consistent with European law. The final section will discuss the status-quo option. 


\subsection{THE CHANGING NATURE OF POSITIONS}

The positions of the social partners have changed over time, particularly as actors have developed their understanding of the ruling and its consequences. At the beginning of this research in March 2008, some of the organisations investigated did not hold an official position on how the Swedish model should change in response to the ECJ ruling. In addition, the positions of organisations that had made a decision were rather tentative, and did not hold a large degree of complexity.

By October 2008, the situation was slightly different. More social partners had publicised their official positions, and the existing positions had become more complex and in some cases altered. October 2008 was by no means the endpoint for the development of such viewpoints. Swedish Enterprise, the largest employers association, had still not taken any official position. Similarly, knowledge about the effects of the ECJ ruling was still developing. As a result, the positions below provide a 'snapshot' of views at a particular point in time.

\subsection{LEGISLATED MINIMUM WAGE}

The first option to be assessed is the model which sets minimum wages through legislation. As discussed in Section 3.7, the legislated minimum wage option represents the largest deviation from the Swedish model, and its implementation would provide an indication of 'significant' change to Swedish industrial relations. It is also perhaps the most contested position found between the various social partners. This difficulty is further exacerbated by its exclusion as an option in the Claes Stråth investigation. As a result, only one social actor advocates this model, and it is not a peak level organisation.

An interesting feature of legislated minimum wage model is that there is no peaklevel organisation supporting its implementation as its first preferred option. This, however, cannot validate the preliminary conclusion that no support for it exists. An important matter is that the main peak level organisation of the private sector employers, Swedish Enterprise, does not hold an official position. The organisation 
suggests, however, that the legislated minimum wage option does have some degree of merit. $^{1}$

In addition to this, Swedish Enterprise's largest and most influential affiliate organisation, the Association of Swedish Engineering Industries (Teknikföretagen), has explicitly stated that the legislated minimum wage option is the best model. ${ }^{2}$ According to Teknikföretagen, it is the best way to maintain the Swedish model. This may suggest this option is a 'de-facto' position of the peak level organisation, or that a fault line exists within the peak level organisation.

While Swedish Enterprise withholds an official position, its comments about the merits of the legislative minimum wage indicate that Swedish Enterprise may see it as a potential system to regulate the Swedish model of industrial relations. ${ }^{3}$ Official $1 \mathrm{~A}$ of Swedish Enterprise, who views the ECJ judgment in the 'narrow sense', argued that a legislated minimum wage is one of only two methods which are compatible with ECJ law (the other being the universal declaration of collective agreements). ${ }^{4} \mathrm{He}$ did, however, suggest that the legislated minimum wage option has pros and cons, and that the confederation had not 'put its foot down'.5 Official 1A suggested that ongoing discussions with the affiliate organisations had not yet reached any conclusion. In the words of the representative official of Swedish Enterprise:

We tried in 2005 to solve the question, but at that time we thought the Laval ruling would be against us, so we did not come to a final point. And with the new ruling in the Laval, it has opened up the debate. But we are not ready, and frankly we are not in a hurry. ${ }^{6}$

In other words, the preliminary ruling by the Swedish Labour Court in 2005 led to a cessation of discussion about the issue. With the new ECJ ruling (which is perceived to be consistent with the interests of Swedish Enterprise) the discussion can be resumed.

Thus, without Swedish Enterprise making public any open position, there is relatively little official pressure for the implementation of a legislated minimum wage.

\footnotetext{
${ }^{1}$ Official 1A, "Interview," (Confederation of Swedish Enterprise, 2008, October 15).

2 Association of Swedish Engineering Industries [Teknikföretagen], "The Swedish Model after Vaxholm," (2008).

3 A, "Interview."

${ }^{4}$ Ibid.

${ }^{5}$ Ibid.

${ }^{6}$ Ibid.
} 
In the current debate this option has been marginalised by all, except for a small, albeit influential affiliate organisation. Importantly, no labour organisations were in favour of this option. Opposition to the legislated minimum wage from both employers and labour diminishes the likelihood of this type of change.

Despite the popularity of legislative minimum wage setting mechanisms throughout Europe, the social partners in Sweden viewed the option with a large degree of scepticism. For both employers and labour, the implementation of a legislated minimum wage was seen to pose challenges to the Swedish model on a number of different levels in spite of any possible benefits. This following section will discuss the arguments against a legislated minimum wage. It will illustrate that four main arguments were used by the social partners: (1) fear of politicisation; (2) cartel preservation; (3) downward pressure on wages; and (4) wider system interests and societal issues.

\section{Fear of Politicisation}

Despite the 'conventional wisdom', public sector employers resisted the minimum wage option at hand. The concern of politicisation of the wage setting process was strong despite the variety of minimum wage fixing procedures which are available. ${ }^{7}$ Swedish Enterprise, despite not having an 'official position', saw the issue of politicisation as a drawback to the legislated minimum wage model. According to Official 1A:

It is easy before an election to say vote for us and you will get 10,000 crowns, or you vote for us and you get 11, 000 crowns. That is not good. ${ }^{8}$

In other words Official $1 \mathrm{~A}$ believes that a legislated minimum wage may mean that in elections, political parties will use wages as an incentive to entice prospective voters.

\footnotetext{
${ }^{7}$ See the following for an in depth overview of the range of options: Francois Eyraud, The Fundamentals of Minimum Wage Fixing (Geneva : International Labour Office, 2005), 1-27.

${ }^{8} 1 \mathrm{~A}$, "Interview."
} 
Similarly, the representative of the public sector employers held strong reservations for the legislated minimum wage option. This fear of politicisation is also a view which is held by the Swedish Agency for Government Employers. In the words of Official 2A:

We, however, feel there is a danger for legislated minimum wages as it is very appealing for politicians to use minimum wages during election periods. In other words there will be a political influence on wages. ${ }^{9}$

Even in a situation where there is a baseline legislative minimum wage alongside collective agreements, SAGE held the view that the risk of politicisation was still strong. ${ }^{10}$ It argued that while the process of increasing wages on the political side would be the same, there would be a difference in the degree to which this would occur. $^{11}$

These statements give insight to the interests of employers and whether they are a coherent group or a group with sharp internal divisions. In this case, the private and public sector employers preferred stability over the prospect of lower wages. This suggests that downward pressure on wages is not as important for Swedish employers as it is for employers in other LME's.

There is further evidence of agreement between labour union officials and employer groups. Official 1A of the Confederation of Swedish Enterprise supported the critique offered by trade union organisations. He believes the trade unions are correct when they argue that Sweden is not used to leaving wage setting to politicians. ${ }^{12}$ This absence of this tradition means that politicians lack the experience and knowledge needed to deal with this issue effectively. Because of this, the 'capturing' and 'exploitation' of government discretion in wage setting as an election campaign tool was believed to be a particular risk for Sweden especially in an environment where the state has little experience in this area of industrial relations. While politicisation is a risk identified by both employers and labour organisations, it was the employers who

\footnotetext{
${ }^{9}$ Official 2A, "Interview " (Swedish Agency for Government Employers [SAGE], 2008, October 14).

${ }^{10}$ Ibid.

${ }^{11}$ Ibid.

${ }^{12} 1 \mathrm{~A}$, "Interview."
} 
identified it as the most significant drawback of the model. In addition to the fear of politicisation, the desire to preserve a cartel amongst the social partners in wage setting resulted in antagonism toward the legislated minimum wage model.

\section{Cartel preservation}

Cartel preservation was a strong imperative for the social partners. They expressed a desire to keep the state out of wage setting procedures as a bi-partite arrangement between labour organisations and employers association would maximise the influence of each party. Third party interference by the state would only serve to dilute their autonomy. In an interview with Official 2A from the Swedish Agency for Government Employers, it was stated that: "we want to keep the state out. This is very strange as we are also part of the state. ${ }^{13}$ These sentiments were further mirrored in an interview with Official 3A the Swedish Trade Union Confederation. In the words of the interviewee:

Our primary function is to set the price of labour and we do it together with those that buy labour, and together we negotiate the price. And we don't want a third actor, the state. $^{14}$

In other words, the social partners share a large imperative to maintain their autonomy in wage setting. This is consistent with Swenson's (2002) notion of social partners in the solidaristic model behaving like a cartel in order to protect their interests. ${ }^{15}$ The legislated minimum wage is perceived to infringe upon this bi-partite arrangement which best serves the social partners. Furthermore, the legislated minimum wage model would infringe upon the ability to set wages at a local level.

Local wages were identified to be of high importance to the social partners. The bi-partite model is seen as an effective way to ensure that where possible, wages are set locally. SACO argued that legislated minimum wages would disturb the local nature of the wage setting process. Depending on the parties involved, the current system allows

\footnotetext{
13 2A, "Interview ".

${ }^{14}$ Official 3A, "Interview," (Swedish Trade Union Confederation [LO], 2008, October 15).

${ }^{15}$ Peter A. Swenson, Capitalists against Markets : The Making of Labor Markets and Welfare States in the United States and Sweden (New York: Oxford University Press, 2002).
} 
wages to be flexible which is important to the organisation. According to SACO Official 5A, the collective agreements to which its member affiliates are associated mainly have a policy of individual pay and not fixed numbers. ${ }^{16}$ Thus, collective agreements typically do not involve numbers, especially when they concern professional associations. ${ }^{17}$ This is in contrast to collective agreements concerning 'blue-collar' workers which often do have precise values in their agreements. According to Official 5A:

Where possible it [wages] should be local and individually agreed and therefore minimum wages could have an impact. We don't like to fix wages, it is against our policy. If an affiliate organisation wants to have a posting in a situation where this is concerned we could probably say that we don't want to have individual pay, but that is up to the affiliate to decide. ${ }^{18}$

In other words, professional associations prefer wage guidelines compared to rigid 'numerical' values as it allows for greater flexibility.

In addition, SAGE supports the perspective that where possible, wages should be locally set. According to Official 2A:

Our collective agreements are very modern, and you can't see anything about minimum wages. You will see wages set on local level. We are not interested in legislated minimum wages, this is very important to us. ${ }^{19}$

In addition to infringing on social partner and local autonomy legislated minimum wage were believed to provide a downward pressure on wages.

Overall, the loss of the wage-setting cartel implies a loss of control. Most of the social partners believe they are able to determine a better and more stable model, rather than preferring short-term incentives offered by 'politicised' wages. This suggests there are shared interests between the sides of labour and employers that the state could potentially undermine.

\footnotetext{
${ }^{16}$ Official 5A, "Interview," (Confederation of Professional Associations [SACO], 2008, 21 October).

${ }^{17}$ Ibid.

${ }^{18}$ Ibid.

${ }^{19} 2 \mathrm{~A}$, "Interview ".
} 


\section{Downward Pressure on Wages}

The possibility of a downward pressure on wages is considered by some to be the primary reason for labour organisations resisting a legislated minimum wage. The downward pressure on wages caused by legislated minimum wages was seen as especially harmful to the interests of blue-collar workers. Official 3A of the LO viewed the impact of minimum wages in the context of class interest. In his view, the primary objective of the employers was to buy labour as cheaply as possible. ${ }^{20}$ In the words of an LO official:

Experience shows that if you have a legislated minimum wage set by the state it will be much lower than if set in an autonomous system. This is because it has to fit across all companies, across all regions, across all sectors and branches. So it won't be the highest common denominator but rather the lowest common denominator. So that's why you see such large differences between paid wages (outgoing wages) and legislated minimum wages, and that's why we don't want this for any reason. ${ }^{21}$

In other words, legislated minimum wages often fall to the lowest level accepted by the range of actors. This is due to government constraints in determining broad 'blanket' levels for the entire labour market.

Further 'alliances' are identified between labour and employers. An area of accord found between trade unions and Swedish Enterprise was the effect that legislation has on the minimum level wages. According to Official 1A, Swedish Enterprise believes that having a legislated minimum wage will mean that outgoing wages will be lower than what has previously been set through collective agreements. ${ }^{22}$ This is due to the difference between the broad nature of wage setting at the state level and the flexible and tailored nature of wage setting found in collective agreements that result from negotiation between the social partners. In the words of Official $1 \mathrm{~A}$ of Swedish Enterprise:

\footnotetext{
${ }^{20} 3 \mathrm{~A}$, "Interview."

${ }^{21}$ Ibid.

${ }^{22} 1 \mathrm{~A}$, "Interview."
} 
The politicians will have to take in to consideration the whole of the labour market, as well as those low paid employees. I don't think they will have the guts to put it an especially high level. ${ }^{23}$

An issue to take into account, however, is whether lower wages are desirable for the respective organisation. The solidaristic model, which underpins Swedish industrial relations, removes wages as a variable for competition between firms. Furthermore, as discussed in Chapter 3, the solidaristic model encourages higher firm investment in individual workers to increase levels of productivity. This is in contrast to the segmentalist model, as found in the US, where worker investment is largely the responsibility of the individual. ${ }^{24}$ This suggests that low wages are not necessarily of importance to private sector employers Sweden and is the result of a particular labour market structure.

\section{Systemic and societal issues}

The fourth area to be addressed is the systemic and societal reasons the social partners may have for opposing a legislated minimum wage. One critique of the legislative minimum wage method is that the price of labour is incorrect. According the Official 3A of the LO:

The core concern is that the price on labour would be wrong, and this will have negative consequences on the economy as a whole. And it would not be good for our members as it would be a negative push on wages. ${ }^{25}$

In other words, this model would have poor results for the overall economy.

Support is identified for the founding values underlying the Swedish model. Another argument against legislation in wages draws upon a broader 'vision' for Swedish society. A particular concern is the effect of a legislated minimum wage on levels of wage disparities. In an interview an official of the LO stated:

\footnotetext{
${ }^{23}$ Ibid.

${ }^{24}$ Swenson, Capitalists against Markets : The Making of Labor Markets and Welfare States in the United States and Sweden.

${ }^{25} 3 \mathrm{~A}$, "Interview."
} 
So it would not only be a technical change, but Sweden will become more like the US. Such as greater wage disparities. It depends on what type of society you want. ${ }^{26}$

This highlights broader societal interests as a driver behind standpoints toward changes in the Swedish model.

Protection of the system as a whole, rather than direct individual interests, was further identified as a motive for opposing a legislated minimum wage. There are some organisations, such as SACO, that believe the effect of legislated minimum wage will be minimal for their respective organisation and affiliates. However, their concern for the system as a whole, and those unions which will be affected, consolidated their stance against the implementation of a legislated minimum wage.

SACO seeks to protect its class interests by rejecting a legislated minimum wage. An example of this is the Swedish Confederation of Professional Associations. According to Official 5A, it is actually quite difficult to determine what the effects of a minimum wage will be on each respective labour organisation. This is because it is unlikely that there will be just one minimum wage. Rather, wages are likely to set according to a number of different criteria and vary depending on the type of work and profession. ${ }^{27}$ Despite this, Official $5 \mathrm{~A}$ believes that it is possible that the effect of a legislated minimum wage would be less detrimental for professional associations than the blue-collar unions. ${ }^{28}$ This is because their member affiliates, as academics, often have quite high wages. As the minimum wages in legislation are likely to be quite low, there would be a large gap between the legislated minimum wage and the existing wages for their members. ${ }^{29}$ This gap, argued Official 5A, would provide a buffer for the affiliates whom her organisation represents.

This suggests that SACO is against legislated minimum wages not out of self interest but rather in the interest in maintaining the system as an entirety.

The above examination of the social partner's positions on the legislated minimum wage option adds some important findings for this study. As outlined in Chapter 3.6, a push toward a legislated minimum wage would indicate change to the

\footnotetext{
${ }^{26}$ Ibid.

${ }^{27} 5 \mathrm{~A}$, "Interview."

${ }^{28}$ Ibid.

${ }^{29}$ Ibid.
} 
Swedish model. Strong pressure toward this would provide an indication of a move to a more European style of industrial relations; this is because the majority of EU member states use legislated minimum wages in some form or another in the regulation of their labour market. Only Denmark and Sweden retain a model that keeps the state out of wage setting procedures.

Our examination shows that there is little support for a shift to legislated minimum wages. The support is from a single voice - the engineering employers association - and there is little support from any other parties. This suggests that the Swedish model is unlikely to undergo a substantial shift to the legislated minimum wage model.

\subsection{UNIVERSAL DECLARATION OF COLLECTIVE AGREEMENTS (ERGA} OMNES)

The method of 'universal declaration of collective agreements', or 'erga omnes', is viewed as a milder alternative to legislated minimum wages. Despite this, significant criticisms have been voiced against its potential ill effects upon the Swedish model. In addition, no peak-level organisation holds this position as its preferred option, although the Confederation of Swedish Enterprise has not yet taken a position. This section will outline the arguments for and against the 'erga omnes' model. It will illustrate four core arguments from the social partners: (1) negative consequences for union membership; (2) the need to protect the wider system; (3) restrictions on that this model may have on the freedom of the social partners; and (4) the lack of an appropriate mechanism for determining which collective agreement is to be extended.

To begin, the perceived negative consequences for union membership will be discussed. One critique of the erga omnes model is that it would reduce union membership rates. This largely stems from the assumption that an existing collective agreement will be extended across a sector or industry. There is little incentive for individuals to stay in a union and continue to pay membership dues as erga omnes would result in automatic coverage. Thus, a 'free-rider' issue would be produced as individuals may find it in their interests to withdraw from unions. This is of particular concern to the LO. According to Official 3A of the LO: 
We don't want this either. And here it is not so much that the price of labour would be distorted because it would be the price we set. Here it could have negative consequences for membership, you may have the free rider problem. ${ }^{30}$

As union membership rates have fallen in Sweden over recent years, continued decline in membership would threaten the future viability of unions in Sweden. ${ }^{31}$ It is not only the unions, however, who oppose 'erga omnes' due to the fear that it will hurt membership rates and union strength.

The Swedish Agency for Government Employers held many of the same concerns as the LO concerning the effects of erga omnes on the Swedish model of industrial relations. An important distinction is that the concern does not address the 'immediate interests', as government employers would not be directly affected; rather, they seek to maintain the wider system. In the opinion of Official 2A of SAGE, erga omnes is best suited to countries with weak unions, where the advantage of this system is that if only $10 \%$ of individuals belong to unions a collective agreement can be extended to cover all employees. ${ }^{32}$ According to Official 2A:

In Sweden we have high unionization rates (80-90\%), but we foresee this system will make unions weaker as people will think, why should we be a member of a union and pay, despite collective agreement already being application. ${ }^{33}$

This illustrates that the LO and SAGE are in agreement of the consequences of a system of universally declared collective agreements. The important distinction, however, is that SAGE seeks to preserve the current system of strong unions for quite different reasons. According to Official 2A:

we as employers are interested in strong unions in which we can bargain with. We also want unions that are representative and have authority. We see they will be weakened and weak unions are not in our interest. ${ }^{34}$

\footnotetext{
30 A, "Interview."

${ }^{31}$ Ibid.

32 A, "Interview ".

${ }^{33}$ Ibid.
} 
The core argument presented by the official from SAGE is that strong unions (and strong employers associations) are the basis for the Swedish model. If collective agreements are going to be the primary tool of wage setting, it is important to have strong partners to bargain with. ${ }^{35}$ According to Official 2A, 'that's the basis of the social dialogue ${ }^{36}$ Bargaining with weak counterpart is subsequently harmful.

The fact that the government employers advocate strong unions, and thus will not support an option that weakens them, suggests that they take a holistic approach, to labour relationships. It is not just individual interests which matter, but rather collective interest - and the overall well-being of counterpart organisations - that is important. This provides evidence that some social partners want to keep the system strong in its entirety.

The next issue to be addressed is the way in which 'erga omnes' infringes upon the 'freedom' within the Swedish labour market. In the opinion of Official 5A from the Swedish Confederation for Professional Association (SACO) it was important that both parties involved in creating the terms and conditions for collective agreements should take full responsibility for the agreement. ${ }^{37}$ 'Erga omnes' would change this, making collective agreements follow legislation, rather than being the responsibility of the bargaining parties. ${ }^{38}$ Thus, extending collective agreements would restrict the freedom of individuals and firms to belong to - or stay outside of - a collective agreement. It would no longer be the decision of the respective trade unions or employers associations, but rather the decision of the state.

The fourth concern raised is the issue of which collective agreements would be extended. This was raised by all of the interviewees but was of particular concern to Official 5A of SACO. A characteristic of the Swedish labour market is that a large number of collective agreements exist over the entire labour market. As currently over 800 collective agreements are in force, this would create the problem of which single agreement to extend. Choosing only one collective agreement would limit the social

\footnotetext{
34 Ibid.

35 Ibid.

36 Ibid.

${ }^{37}$ 5A, "Interview."

${ }^{38}$ Ibid.
} 
partners' range of choices, and freedom on the labour market would be disturbed. In the words of the official representing SACO:

In Sweden we have a 'free market' of collective agreements. It up to the unions to decide whether they want to try to get a collective agreement. Many employers have more than one collective agreement. And if you have this option, the freedom at the labour market level will be disturbed. ${ }^{39}$

In other words, the social partners believe that the universal declaration of collective agreement model would hinder their freedom and autonomy.

\subsection{EXTENSION MODEL}

The debates over the legislated minimum wage model and the system of universal declaration are noticeably clearer than those of the 'extension model'. As discussed in Section 3.8, this may be due to the occurrence of countries, both within and outside the EU, having clear examples of these previous systems. In contrast, the extension model has no concrete examples in the EU other than Denmark. The model, which was developed recently, made its first appearance in the 1996 Posting of Workers Directive. ${ }^{40}$ The extension model can be identified as the options that are possible under Article 3(8) of the Posting of Workers Directive.

Significant debates have developed over the interpretation of Article 3(8), indicating a lack of clarity. There is also significant division over the desirability of applying the extension model to the Swedish model. There are two competing arguments against the extension model. First, an interpretation in the narrow sense views it as being an untried and untested type of 'erga omnes'. The extension model interpreted in the wide sense (autonomous collective agreements), however, is viewed by some parties as inconsistent with EC law.

Overall, a number of influential parties support the extension model, indicating that for them, the benefits outweigh its drawbacks. A note must be made that in many cases this model is defined in the 'negative' sense. In other words, actors often 
describe all the things they don't want, and label what is left as this 'extension model'. Reference is often made to Claes Stråth as the enquiry group who will define what the 'extension model' really is. Some actors, however, have been more successful in clearly stating what it is and why it would be the best solution for the ECJ Laval ruling. An initial problem identified with the extension model is its lack of clarity. This lack of clarity is the result of the hurried way in which it was included in the Posting of Workers Directive. As a result, EU countries have been reluctant to use this model. According to Official 1B of Teknikföretagen:

It was created in the very last minutes of the negotiations concerning the directive. Those taking part in the discussion were not labour law experts. None of the member countries in the EU have used it, and the main reason for not using it is because it is legally unclear. $^{41}$ None of the legal experts in Swedish universities (myself included) can understand the text directive when it comes to the extension model. ${ }^{42}$

This extension model was created as a fog to be able to get this through the two countries that did not have either of those: and there are only two Denmark or Sweden. All of the others have one of those two, or a combination of both. ${ }^{43}$

Some social partners consider the status of the extension model to be unclear. Those, such as the LO and TCO, however, believe that with time and the efforts of the Claes Stråth investigation, confusion will by resolved and a viable and successful solution will be reached. This view is not, however, shared by Swedish Enterprise or Teknikföretagen. According to these actors, the lack of clarity raises serious legal issues, which are likely to be harmful to the Swedish model.

A core critique of the extension model is that it is just a type of 'erga omnes' in disguise. In particular, it holds many of the drawbacks of the erga omnes system without any obvious benefits. In the opinion of Official 1B of Teknikföretagen, an analysis of the Posted Workers Directive indicates that only two legal options exist:

\footnotetext{
${ }^{41}$ Official 1B, "Interview," (The Association of Swedish Engineering Industries [Teknikföretagen], 2008, October 30).

${ }^{42}$ Ibid.

${ }^{43}$ Ibid.
} 
My conclusion is if you analyse the PWD, there are only two legal options: by law, or by collective agreement that has been declared clearly and obviously by the member state universally applicable legislated minimum wages or erga omnes. ${ }^{44}$

This viewpoint is shared by the peak level employers association for private sector employers, Swedish Enterprise. According to Official 1A of Swedish Enterprise 'you can say there are two ways, by legislated minimum wage and by collective agreement. $^{45}$

Official 1A presented a stronger argument that this 'third' option is just another form of erga omnes:

The LO does not want to acknowledge that it is erga omnes. They do not want to acknowledge that the obligations according to the PWD is on the members states. The member states cannot delegate to parties to regulate this on an ad hoc basis. They can use regulation that the social partners have mapped. Declaring this regulation generally applicable either through a traditional erga omnes, or some variation that must then meet those criteria. ${ }^{46}$

In sum, Swedish Enterprise argues that the only way that this model could be implemented to be consistent with EC law is by replicating the erga omnes model.

\section{Inconsistent with EC law}

A major problem, however, is that the extension model is inconsistent with European law particularly if viewed in the 'wide sense' of the autonomous collective agreement model. The extension model has been only used by one other country within the European Union, that being Denmark. Both Swedish Enterprise and Teknikföretagen believe, however, that there are serious problems with the model that has been used by Denmark. According to Official 1B of Teknikföretagen:

\footnotetext{
${ }^{44}$ Ibid.

45 A, "Interview."

${ }^{46} 1 \mathrm{~B}$, "Interview."
} 
Denmark has used what they think is some variation of the extension model, but if you talk to those behind the scenes who are involved in the negotiations (on the employers side anyway), they are convinced that the implementation model from Denmark is not in line with EU law. ${ }^{47}$

This shortcoming of the extension model in Denmark is also identified by Official 1A of Swedish Enterprise:

For example the Danish model, in my opinion, is not in accordance with EU legislation. The Danish are tired of the question, they want legislation so they can put the issue behind them. They don't mind waiting ten or so years until the ECJ says that we are wrong. They can live with that.

Thus, according to Official 1A of Swedish Enterprise, the Danish application of the extension model is likely to come under ECJ scrutiny in future years. These opinions suggest that Swedish Enterprise clearly views the ECJ Laval ruling in the 'narrow' sense. This is further confirmed by Official $1 \mathrm{~A}$ in the statement that the direction of the Claes Stråth investigation 'raises many legal questions with regard to European legislation. ${ }^{48}$ It is believed that the Claes Stråth investigation is likely to deliver a decision that is not in accordance with European Law. ${ }^{49}$ While private sector employers have made legal criticisms, additional problems have been identified with the extension model.

\section{Transparency}

The lack of transparency is a significant shortcoming of the extension model from the perspective of by both Swedish Enterprise and Teknikföretagen. Particularly, there is some reservation over whether it is possible to make existing collective agreements as transparent as required by the ECJ. Official 1B of Teknikföretagen stated:

\footnotetext{
${ }^{47}$ Ibid.

${ }^{48} 1 \mathrm{~A}$, "Interview."

${ }^{49}$ Ibid.
} 
A serious legal evaluation of the extension model [is needed], if it will meet the criteria of being transparent and legally binding. ${ }^{50}$

This critique is backed by Swedish Enterprise, suggesting widespread support across the private sector employers. ${ }^{51}$ Official 1A of Swedish Enterprise expects there to be significant problems if the extension model is projected on to the current system of collective agreements. He notes that many collective agreements do not set a minimum wage. ${ }^{52}$ Thus, to follow the extension model will require those collective agreements to be changed or renegotiated to include a minimum wage. ${ }^{53}$

Official 1A also believed that the extension model would have an upward influence on wages:

From my point of view, one risk is that the minimum pay level will be rather high [it will force wages up].

And that has an impact on all wage levels above. It will push them upwards. There are studies that show this. And there are also studies that also show that if you have a high minimum wage which exclude youth, there are some disadvantages to that model. ${ }^{54}$

Thus, this suggests that although low wages are not necessarily a sticking point for Swedish Enterprise, overly high wages are not conducive for the interests of the organisation.

In summary, Swedish Enterprise and Teknikföretagen were very critical of the extension model. In their opinion, the extension model is unclear due to the hasty way in which it was incorporated into the Posting of Workers Directive. It also makes it difficult to achieve transparency, and according to Swedish Enterprise, may push wages upward. The other two critiques, however, appear to be explicitly linked to the framing of the ECJ ruling. Both Swedish Enterprise and Teknikföretagen viewed the extension model as just another form of erga omnes. Second, it was argued that it is

\footnotetext{
${ }^{50} 1 \mathrm{~B}$, ,Interview."

${ }^{51} 1 \mathrm{~A}$, "Interview."

${ }^{52}$ Ibid.

53 Ibid.

${ }^{54}$ Ibid.
} 
highly likely that it would result in a similar model as the Danish model, which is expected to be inconsistent with EC law.

Despite these strong reservations from both Swedish Enterprise and Teknikföretagen, the majority of the actors within the Swedish model considered the extension model to be the best way to protect the Swedish model from the effects of the ECJ ruling.

The Swedish Agency for Government Employers (SAGE) has clearly stated that the extension model is its preferred option. ${ }^{55}$ But like the other employers association, it gave no clear definition of the model. Rather, it appears that SAGE prefers it because it rejects the two other options available: the legislated minimum wage, and erga omnes. According to Official 2A:

This third way [extension model] is very interesting to us. It is very difficult to say exactly what it is but the Swedish investigation has an idea of the model which can be applied. This is the model we advocate. ${ }^{56}$

SAGE has stated that it does not want legislated minimum wages or erga omnes, and this narrows the scope of available options. As the Claes Stråth investigation is confident that it can provide a third solution, SAGE trusts that the extension model will provide the best outcome.

\section{Autonomous Collective Agreements}

The autonomous collective agreements option - part of the extension model - has been the 'redeeming' option for many of the social partners. Particularly from the side of labour, autonomous collective agreements are believed to have the smallest impact on the Swedish model of industrial relation out of the four options. While this may be the case, the social partners who advocate this position are not entirely explicit about how this option will work in practice. Those that advocate this model do so because they do not support legislated minimum wages or erga omnes. There is room in the

\footnotetext{
${ }^{55}$ 2A, "Interview ", Karl Pfeifer, "Laval-Utredningen (Laval-Investigation)," (Swedish Agency for Government Employers [SAGE], 2008).

${ }^{56} 2 \mathrm{~A}$, "Interview ".
} 
PWD in Article 3.8 to do something else, and Claes Strath agrees that this option is possible.

The method of autonomous collective agreements has attracted a lot of attention from the social partners. In essence, it causes the least amount of change to the current industrial relations system, and this suggests why the option is viewed so favourably. Official 5A stated that SACO advocated the autonomous collective agreements model. ${ }^{57}$ This is based on their desire for minimal change to the Swedish model, as only subtle changes in legislation are believed to be needed. Official 3A of LO and Official 4A of TCO put forth joint statements. Because the autonomous collective agreement is a viable option, 'it is the best solution to the current problem' ${ }^{58}$

Each of these interpretations are based on a 'broad' reading of the ECJ ruling. According to Official 5A, SACO believes that it is not necessary to implement a legislated minimum wage or erga omnes because the PWD does not prohibit other systems, it only ensures the free movement of services. ${ }^{59}$ Thus, the best option is to preserve the current system with some slight alterations to ensure compatibility with EC law. ${ }^{60}$

According to Official 3A from the LO, and Official 4A from TCO, two primary changes need to be made to the Swedish model for the autonomous collective agreement to be consistent with the ECJ Laval ruling. These are: first, the legal framework for the autonomous collective agreement model needs to work properly; and second, the area of 'large work' needs to be addressed. ${ }^{61}$ These measures are supported by SACO. ${ }^{62}$

Official $3 \mathrm{~A}$ argued that the following changes were needed to consolidate the legal framework: change Lex Brittania; determine what collective agreements can require in terms of work conditions; and clarify for foreign companies the associated labour costs of undertaking work in Sweden.

The second major change is in the area of 'large work'. This relates to changing the collective agreements that are currently used by the social partners. In particular, it means ensuring that collective agreements applied to foreign undertakings are

\footnotetext{
${ }^{57} 5 \mathrm{~A}$, , Interview."

${ }^{58} 3 \mathrm{~A}$, "Interview."

${ }^{59} 5 \mathrm{~A}$, "Interview."

${ }^{60}$ Ibid.

${ }^{61} 3 \mathrm{~A}$, "Interview."

${ }^{62} 5 \mathrm{~A}$, "Interview."
} 
transparent. ${ }^{63}$ Official 3A stated that the current lack of transparency is due to the way collective agreements have developed over time. ${ }^{64}$ They have grown from over 120 years of negotiations and express the power balance between labour and capital. ${ }^{65}$

Official 5A agrees that a significant amount of work is required to ensure that collective agreements are transparent. According to Official 5A of SACO:

The judgement states [that] you need transparency and clear and defined condition. Perhaps that needs to be said in legislation but you don't have to say in the legislation which collective agreements will be applied to foreign companies. ${ }^{66}$

According to Official $3 \mathrm{~A}$, the LO views the autonomous collective agreement option as the most viable course of action. ${ }^{67}$ This model is not without problems, however, but it sees it as superior to the legislated minimum wage and the erga omnes option. According to Official 3A, transparency will be difficult to establish in some areas, but can be achieved.

Within the blue-collar areas (and the related unions), there will not be a great deal of work required in order to make collective agreements more transparent. The white-collar unions, however, may face greater challenges. This is because within their collective agreements, numbers and figures are generally not found. Instead, such agreements tend to include a set of principles on how to set wages. ${ }^{68}$

The issue of posted workers is not as pressing for white-collar unions as for bluecollar unions in areas such as construction. As a result, there may not be a need to make the collective agreements in these areas significantly more transparent. According to Official 3A of LO:

Introducing transparency for collective agreement means quite a lot, and if you don't have the problem of posted workers you should not go through the process. So I think you will have a lot of disobedience in a lot of branches and sectors as a consequence. ${ }^{69}$

\footnotetext{
${ }^{63} 3 \mathrm{~A}$, "Interview."

${ }^{64}$ Ibid.

${ }^{65}$ Ibid.

${ }^{66} 5 \mathrm{~A}$, "Interview."

67 3A, "Interview."

${ }^{68}$ Ibid.

${ }^{69}$ Ibid.
} 
If the sectors where posted workers are sent change significantly in the next future years, there may be a need to make the collective agreements for white-collar workers more transparent. ${ }^{70}$

In summary, LO, TCO and SACO believe the autonomous collective agreement model is the best way to safeguard the Swedish model. These social partners all believe there is room in Article 3.8 to do this.

\subsection{STATUS-QUO}

This option has been surprisingly popular with many of the social partners, although no actor has officially placed it as their preferred option. In some respects, many groups see this option as changing the Swedish model very little, assuming that the Swedish model will still hold for Swedish workers. The distinguishing feature of the model is that foreign employers are able to enter Sweden on the conditions of a home collective agreement, and unions are unable to take industrial action to improve the conditions for those foreign workers. ${ }^{71}$

Because the Laval ruling affects the different sectors to varying degrees, some social partners have shown indifference to this option. As such, many of the social partners have experienced little direct impact from the Laval ECJ ruling. Swedish Enterprise has not expressed an official position, however, they identify both advantages and disadvantages to this method.

Several of the peak level social partners have the view that the status-quo option will not particularly harm their organisation. Discussion with these actors suggests that the direct effects of the ECJ Laval ruling will have the largest impact on blue-collar organisations, particularly those belonging to the LO. The Swedish Agency for Government Employers (SAGE) has stated that this ruling does not have a significant effect on government employers because state employers are insulated from the issue of posted workers. In the words of Official 2A of SAGE:

This is interesting that you mention this option as we have talked about this. It would be okay for us, because we don't have any problems with the Laval case. But for those

\footnotetext{
${ }^{70}$ Ibid.

${ }^{71}$ Industrial action is permitted if no collective agreement exists.
} 
organizations that really need a collective agreement with a foreign company this could be a problem. But we have tested this idea but it means that the unions have no legal right to take industrial action. This other option [extension model], however, gives unions the right to industrial action. ${ }^{72}$

The same perspective was found in the Swedish Confederation of Professional Associations (SACO). The university trained professional employees that they represent are not usually subject to low wage competition from low income countries. Official 5A from SACO gave an indication of some of the diversity that exists within the organisation:

An example is the health area [particularly doctors]: they don't have a great problem, because in this sector they are dominant as a union and have high wage levels. When foreign doctors come to Sweden they do not have low wages, and often have higher wages. This is an example where it is not a problem for them. They perhaps are not worried.

Then you have other unions where you see their freedom being constrained. But when looking at solutions there is no conflict. Engineers, that would be one area. Engineers also appear in different branches, it may be building construction, it could be telecommunications, so in their market there are different branches, and it is more unpredictable because their members work in different branches and there could be more risk. $^{73}$

In other words, in areas such as health, Swedish workers are generally paid less than the foreign competitors. ${ }^{74}$ This is due to the compressed nature of wages in the Swedish model of industrial relations. In other areas, such as engineering, that may be spread over a number of sectors and thus covered by more than one peak-level union umbrella organization, professional workers may be exposed to greater low-wage competition. In aggregate, however, the issue of posted workers is not critical for

\footnotetext{
72 A, "Interview ".

73 A , "Interview."

${ }^{74}$ See the section on the solidaristic model
} 
SACO and subsequently the status-quo option would not hurt the organization and its members. $^{75}$

Despite the compatibility with the status-quo option, neither of these organizations held it as their preferred option in the Laval discussions. On the contrary, SACO and SAGE preferred other models as this may harm other unions in the Swedish model. In the words of Official 2A of SAGE:

I would say that we are interested in good relations with the unions. But we also have our own unions, and those unions affected by the Laval ruling do not belong to us. But we do not want to upset the unions. If they were our unions we would perhaps be much more careful, but they are not our unions.

I must handle things in a way so as to maintain good relations with other employers associations. Because we cooperate with the private employers associations and I can't act in a way that makes life harder for them. ${ }^{76}$

In other words, government employers did not wish to act in a way that would harm other unions, even those with whom they were not directly affiliated. This suggests a strong incentive to protect the overall model and promote a position where common ground can be found.

The same behaviour was identified in the professional union representative, although this was more expected if assessed from a class-centred analysis because SACO is a labour representative. Official 5A similarly stated that the status-quo option was not the organisation's official position, and instead it sought a more collaborative approach. According to Official 5A:

We work together, we meet almost every week. We cooperate, but then the reality looks a bit different and we don't always have the same position. We think, however, that we cooperate well and we have to respect our different realities but we don't always have the same opinion. But we have the same position that we want to find a solution which fits within the model of [autonomous] collective agreements. ${ }^{77}$

\footnotetext{
${ }^{75} 5 \mathrm{~A}$, ,Interview."

${ }^{76} 2 \mathrm{~A}$, "Interview ".

77 5A, "Interview."
} 
According to Official 5A it is important for SACO to work in a manner that promotes the greatest degree of consensus. Other social partners were against the status-quo option because it harmed their interests directly. There is evidence to suggest, however, that SAGE and SACO would not act in a way that would harm the interests of the broad array of social partners.

\subsection{CONCLUSION}

The above findings illustrate the debates and pressures within the Swedish model in response to the Laval ECJ ruling. These positions are illustrated in Table 4.1. In the context of the four options assessed above, the strongest response appeared to be in favour of the extension model and, in particular, its subset the autonomous collective agreement model. This option would represent the least change to the Swedish model in response to European integration. However, this 'most favoured' solution is not uncontested.

The legislated minimum wage option was the model that would represent the most significant change to the 'Swedish model' outlined in Section 3.6. Interestingly, all peak level organisations saw significant problems with this option. While this model is used extensively throughout the European Union and the rest of the world, it was seen to pose a significant challenge to the Swedish model. Problems identified by the social partners included a unanimous fear of politicisation, and of the removal of the monopoly that the social partners hold on both sides of labour and capital. A concern to the peak level organisations (Swedish Enterprise, SAGE, LO, TCO, and SACO) was the negative consequence of state involvement in wage setting. In addition, some social partners saw downward pressure on wages and wider systemic issues as potential drawbacks. As a consequence, no peak level organisation held legislated minimum wages as their official position. The main supporter of this option was the Swedish Enterprise affiliate Teknikföretagen. Swedish Enterprise, while identifying some merit alongside concerns was, however, unable to articulate any formal position. This subsequently weakened the already marginalised support for significant change to the Swedish industrial relations through a legislated minimum wage. 
Table 4.1 Positions of Social Partners

\begin{tabular}{|c|c|c|c|c|c|}
\hline & Organisation & $\begin{array}{l}\text { Legislated } \\
\text { Minimum } \\
\text { Wage }\end{array}$ & $\begin{array}{l}\text { Universal } \\
\text { Declaration of } \\
\text { Collective } \\
\text { Agreements } \\
\text { (Erga Omnes) }\end{array}$ & $\begin{array}{l}\text { Extension } \\
\text { Model } \\
\text { (Autonomous } \\
\text { Collective } \\
\text { Agreement } \\
\text { Model) }\end{array}$ & $\begin{array}{l}\text { Status- } \\
\text { quo } \\
\text { model }\end{array}$ \\
\hline \multirow[t]{4}{*}{$\begin{array}{l}\text { Employer } \\
\text { Associations }\end{array}$} & $\begin{array}{l}\text { Confederation } \\
\text { of Swedish } \\
\text { Enterprise }\end{array}$ & NoP & NoP & $\mathrm{NoP}$ & NoP \\
\hline & Teknikföretagen & $\checkmark$ & $X$ & $X$ & $\mathrm{X}$ \\
\hline & EIO & NoP & NoP & NoP & NoP \\
\hline & $\begin{array}{l}\text { Swedish Agency } \\
\text { for Government } \\
\text { Employers } \\
\text { (SAGE) }\end{array}$ & $X$ & $\mathrm{X}$ & $\checkmark$ & $X$ \\
\hline \multirow[t]{4}{*}{$\begin{array}{l}\text { Employee } \\
\text { Associations }\end{array}$} & $\begin{array}{l}\text { Swedish Trade } \\
\text { Union } \\
\text { Confederation } \\
\text { (LO) }\end{array}$ & $\mathrm{X}$ & $X$ & $\checkmark$ & $X$ \\
\hline & Handels & $\mathrm{X}$ & $\mathrm{X}$ & $\checkmark$ & $X$ \\
\hline & $\begin{array}{l}\text { Swedish } \\
\text { Confederation } \\
\text { of Professional } \\
\text { Employees } \\
\text { (TCO) }\end{array}$ & $\mathrm{X}$ & $\mathrm{X}$ & $\checkmark$ & $\mathrm{X}$ \\
\hline & $\begin{array}{l}\text { Swedish } \\
\text { Confederation } \\
\text { for Professional } \\
\text { Associations } \\
\text { (SACO) }\end{array}$ & $X$ & $\mathrm{X}$ & $\checkmark$ & $X$ \\
\hline
\end{tabular}

Source: Official Interviews and Position Documents $\quad$ NoP: No official position

The Universal Declaration of Collective Agreement model (also called the ergaomnes option) is characterised as a change to the Swedish model, but to a lesser degree than the legislated minimum wage option. This model was also unpopular among the social partners, with no peak level or affiliate organisation holding this as their first option. Although it was identified as having undesirable characteristics, the erga omnes option was not considered as severe as the legislated minimum wage system. Social partners expressed fears that it would lead to negative consequences for union 
membership and restrictions on the freedom of unions and employer associations to enter a collective agreement of their choice. Furthermore, there was an absence of appropriate mechanisms to determine which collective agreement is to be extended. A broader reason for opposition, voiced by several social partners, was the desire to protect the wider system of the Swedish model, which they perceived erga omnes would undermine.

The extension model (or its subset, the autonomous collective agreement model) proved to be the option preferred by the Swedish social partners. This model would result in the least amount of change to the Swedish model. The main areas of change considered were revision of 'Lex Brittania' and work around making collective agreements more transparent. This however, is seen as an 'unsubstantial change' rather than an identifiable realignment for the Swedish model. The main private sector employers association, Swedish Enterprise, and its influential affiliate, Teknikföretagen, strongly critiqued the suitability of the autonomous collective agreement model. Their arguments identified four systemic problems with the solution. First, the model was deemed to be unclear and the result of hasty amendments to the Posting of Workers Directive (96/71/EC). Second, it was believed to be another form of erga omnes in 'disguise'. This point is particularly salient if a narrow interpretation of the ECJ ruling is taken, labelling much of the work done by the Claes Stråth investigation as inconsistent with EC law. This leads to the third argument that this option is inconsistent with European law. Such claims are based on perceived flaws with the Danish system of industrial relations. And fourth, it was believed that the transparency objectives would not be feasible, instead having an inflationary effect on wages.

The fourth and final option considered is the status-quo model. This option can be characterised as minimal change or significant change, dependent on the perspective taken. For Swedish workers, the current system of collective agreements (and the Swedish model) would still be viable within the Swedish labour market. For foreign posted workers on the other hand, there would be a de-facto liberalisation of the labour market.

As expected, none of the peak level or affiliate organisations held this choice as their preferred position. However, the reasons behind this were complex. Employer 
and employee associations in the high-skill or protected sectors saw this option as having little direct impact on their organisation. As a result, it was believed to be a good solution if viewed purely from the direct interests of their respective organisations. These social partners, however, did not support this option due to the negative effects on other actors within the wider Swedish model. This supports the observation - identified in the other options - that there is a strong impetus to uphold the overall 'health' of the Swedish model of industrial relations, rather than acting to increase benefits for a single actor.

The next chapter will examine the institutionalised constraints that have shaped these positions. It will also assess the impact of the Claes Stråth investigation and the Head Agreement on the positions of the social partners. 
1A, Official. "Interview." Confederation of Swedish Enterprise, 2008, October 15.

1B, Official. "Interview." The Association of Swedish Engineering Industries [Teknikföretagen], 2008, October 30.

2A, Official. "Interview ": Swedish Agency for Government Employers [SAGE], 2008, October 14.

3A, Official. "Interview." Swedish Trade Union Confederation [LO], 2008, October 15.

5A, Official. "Interview." Confederation of Professional Associations [SACO], 2008, 21 October.

[Teknikföretagen], Association of Swedish Engineering Industries. "The Swedish Model after Vaxholm." 2008.

Eyraud, François. The Fundamentals of Minimum Wage Fixing Geneva : International Labour Office, 2005.

Pfeifer, Karl. "Interview." Swedish Agency for Government Employers [SAGE], 2008, October 14. . "Laval-Utredningen (Laval-Investigation)." Swedish Agency for Government Employers [SAGE], 2008.

Swenson, Peter A. Capitalists against Markets : The Making of Labor Markets and Welfare States in the United States and Sweden: New York : Oxford University Press, 2002.

Swenson, Peter, and Jonas Pontusson. "The Swedish Employer Offensive against Centralized Wage Bargaining." In Unions, Employers, and Central Banks: Macroeconomic Coordination and Institutional Change in Social Market Economies edited by Torben Iversen, Jonas Pontusson and David Soskice: Cambridge University Press 2000.

Weihe, Anders. "Interview." 2008. 


\section{The Claes Stråth Investigation and Head Agreement}

Various actors within Sweden have formulated positions on how the Swedish labour market model should change in response to the Laval ruling. These positions, however, are not wielded with an equal level of authority; nor have they received the same degree of attention. The previous chapter documented the official positions of the main actors; this chapter focuses to how institutional arrangements may shape the influence of particular positions and/or actors. As highlighted in the literature review, institutions may influence behaviour by shaping preferences or interests, constraining options, and providing incentives/disincentives for particular types of action.

This chapter responds to this issue by looking at the core enquiry of the Laval case: the Claes Stråth investigation. It will discuss what role the Claes Stråth enquiry plays in determining how the Swedish model will change, or remain static, within the context of the ECJ ruling. Specifically, it will determine whether the investigation constrains or aids the positions advocated by the social partners. Another issue to be assessed is the impact of the renegotiation of the new 'Head Agreement' on the Claes Stråth investigation.

This chapter will do so in the following way. First, it will assess the structure of the Claes Stråth enquiry and discuss the nature of the enquiry and its directives. Second, this chapter will assess the perspectives of the social partners toward the investigation and determine whether the Claes Stråth investigation constrains or aids social partner influence. Thirdly, it will evaluate the impact of the new Head Agreement on the investigation, paying particular attention to issues of the agreement's timing, issue-linkage and use in limiting options. Fourth, this chapter will draw on how the Claes Stråth investigation acts as an institution that affects the Swedish labour market.

Before embarking on the more substantive part of the chapter, some contextual remarks will be helpful. The Claes Stråth enquiry is a government-led investigation set 
up to make recommendations to the Swedish government on the changes needed for the Swedish labour market model to be compatible with the ECJ Laval ruling. While the government is not bound in any way to implement its proposals, the conclusions will be the single most authoritative source in Sweden on the issue, particularly with regard to detail of policy design. The enquiry has a large degree of political autonomy and widespread legitimacy amongst interest groups and social partners. It is likely to provide a framework for discussing issues related to Laval case by explicitly and implicitly demarcating those areas which are considered to be 'legitimate' or 'illegitimate'.

\subsection{STRUCTURE OF THE INVESTIGATION}

\section{Participant Groups}

The structure of the enquiry deserves attention as its institutional design may influence its final recommendations. The enquiry is driven and accountable to a single actor, the Swedish state. Currently, Sweden is governed by a four party centre-right coalition called the Alliance for Sweden which is composed of the following parties: the Moderate Party, Centre Party, Liberal Peoples Party, and Christian Democrats. Led by the Moderate Party, the Alliance for Sweden was responsible for setting up the investigation. As a result, there is little room to influence the initial design and structure of the enquiry except through the political parties directly. It is based on the founding principles of the political parties at hand, particularly regarding the normative goals of what they want for the Swedish model. Thus, rather than allowing for a wide scope of analysis, the enquiry is designed to meet political needs.

The theme of a 'single driver' is reinforced by the structure of the investigation. It is headed by Claes Stråth, who is Director-General of the Swedish National Mediation Office, a state appointed post. ${ }^{1} \mathrm{He}$ is supported by a three person secretariat from the ministries of Labour, Industry, and Foreign Affairs. ${ }^{2}$ A group of seven

\footnotetext{
${ }^{1}$ Ministry of Employment, "Committee Terms of Reference " (Consequences of action in response to the Laval judgment; decision at a Government meeting on 10 April 2008).

${ }^{2}$ Claes Stråth, "Interview," (National Mediation Office, 2008, October 30).
} 
experts, most of whom are from the government, was also appointed by the state. ${ }^{3}$ The implication is that the report is driven by a single person, Claes Strath. He has some latitude to unilaterally frame the issue and the government's directives.

Despite this, Stråth is provided with a large degree of support and expertise by the three person expert group and secretariat. This apparatus is viewed as sufficient with regard to technical support and cross fertilisation of expert viewpoints.

The structure of the reference group, however, creates some constraints on the ability of interest groups to influence the inquiry. One tier below this is a reference group with representatives from six main social partners: Swedish Enterprise, SAGE, LO, TCO, SACO, and the Association of Local Authorities. ${ }^{4}$ Claes Stråth chose to have a reference group with three representatives from trade unions and three from employers associations. ${ }^{5}$ The individuals themselves, however, were appointed by the respective organisations.

An important observation is that the reference group is limited to a representative from each of the peak level organisations. This brings forth issues that were raised earlier regarding the constraining effects of these peak level organisations. The structure of the reference group fails to recognise certain divisions that exist within each umbrella organisation. Furthermore, it reduces the voice of affiliates that may form cross-class alliances on specific issues.

Nevertheless, the wide number of groups consulted during the process, adds to the integrity and inclusiveness of the investigation. During the process of the investigation, the group followed a wide consultation process, meeting approximately 11 academics from Sweden, Finland, Norway, and Denmark. ${ }^{6}$ In addition, it has consulted with government officials from Finland, Norway, Denmark, and Germany, and met twice with European Commission representatives. ${ }^{7}$ Thus the investigation has taken an inclusive approach, with the objective of wide consultation with experts from academia, government, and the social partners.

Another important parameter is the timeline for the investigation. Some groups, such as parliamentary members, have argued that it is too long specifically with regards

\footnotetext{
${ }^{3}$ Ibid.

${ }^{4}$ Ibid.

5 Ibid.

${ }^{6}$ Ibid.

${ }^{7}$ Ibid.
} 
to the timing for ratification of the Lisbon Treaty. ${ }^{8}$ Members of the enquiry, as well as the government, however, firmly insist that the timeline is already pressured. The government mandate on the enquiry was delivered on 10 April 2008 with the final report due no later than 15 December 2008 (Approximately 8 months). ${ }^{9}$

Thus, the structure of the investigation does place some restrictions on the way the investigation is operationalised. This composition is illustrated in Figure 1.1.

\begin{tabular}{|c|c|c|c|}
\hline Chair & & Claes Stråth & \\
\hline Secretariat & Labour & Industry & Foreign Affairs \\
\hline Expert group & \multicolumn{3}{|c|}{7 person government expert group } \\
\hline $\begin{array}{l}\text { Reference } \\
\text { group }\end{array}$ & \multicolumn{3}{|c|}{$\begin{array}{c}\text { Labour: LO, TCO, SACO } \\
\text { Employers: Swedish Enterprise, SAGE, Association of Local } \\
\text { Authorities }\end{array}$} \\
\hline $\begin{array}{l}\text { Consultation } \\
\text { group }\end{array}$ & \multicolumn{3}{|c|}{$\begin{array}{c}\text { Academics, national level government officials, European } \\
\text { Commission representatives }\end{array}$} \\
\hline
\end{tabular}

Figure 5.1. The Claes Stråth investigation

This study identifies the unilateral nature of the enquiry as a constraint in some measure. In addition, social partner representation is limited to 'peak-level' (and thus class based) organisations. A note must be made that there are limitations to looking just at the structure. However, Stråth does have a deep understanding of the complexities and divisions that exist among the peak level organisations. ${ }^{10}$ This is likely to mitigate the issues of representation discussed above. Furthermore, a larger reference group may make the investigation more cumbersome. The directives of the

\footnotetext{
${ }^{8}$ Swedish Parliament, "Response to Interpellation 2007/08:483 on the Investigation in Response to the Laval Case," (Parliamentary Protocol, 2008, March 10).

${ }^{9}$ Employment, "Committee Terms of Reference ", 1.

${ }^{10}$ View of the author deduced from Stråth, "Interview."
} 
investigation, however, do suggest that important constraints have been imposed on Stråth from above.

\section{Directives}

The Directives outline the ways in which the investigation can approach the ECJ ruling and provide parameters for what can and cannot be included in the investigation. These guidelines have been criticised as an unnecessary 'constraint' and as a result have come under severe criticism by some social partner bodies. Other organisations, by contrast, view the directives as appropriate and highlight examples of flexibility that suggest an extensive range of options have been considered during the course of the investigation.

The core areas of the enquiry's remit are the following: (1) maintain the Swedish model; and (2) ensure compatibility with European law and the ECJ ruling. The first objective of the enquiry is to:

maintain the fundamental principle in the Swedish labour market, that the main responsibility for regulating pay and employment conditions has been assigned to the social partners. ${ }^{11}$

This shows the commitment of the enquiry to not move beyond what is considered to be the core of Swedish industrial relations: keeping the state out of regulating pay and employment conditions. ${ }^{12}$ The second core objective of the Claes Stråth enquiry is to ensure that:

Community law, principally the provisions of the EC Treaty on the freedom of movement of services and the principle of non-discrimination on the grounds of nationality, and the Posting of Workers Directive, as these rules have been defined by the European Court of Justice, shall be fully respected. ${ }^{13}$

\footnotetext{
${ }^{11}$ Employment, "Committee Terms of Reference ", 12.

${ }^{12}$ Stråth, "Interview."

${ }^{13}$ Employment, "Committee Terms of Reference ", 12.
} 
In other words, the enquiry will only consider changes at the national level. It does not examine options for change at the European level; nor does it advocate any positions that may be rejected by the European Court of Justice at a later stage. Therefore, the options to be considered by the enquiry fall within the area of overlap between the following three areas: maintenance of the Swedish model of industrial relations; EC community law; and change at the national level. See Figure 5.2 below.

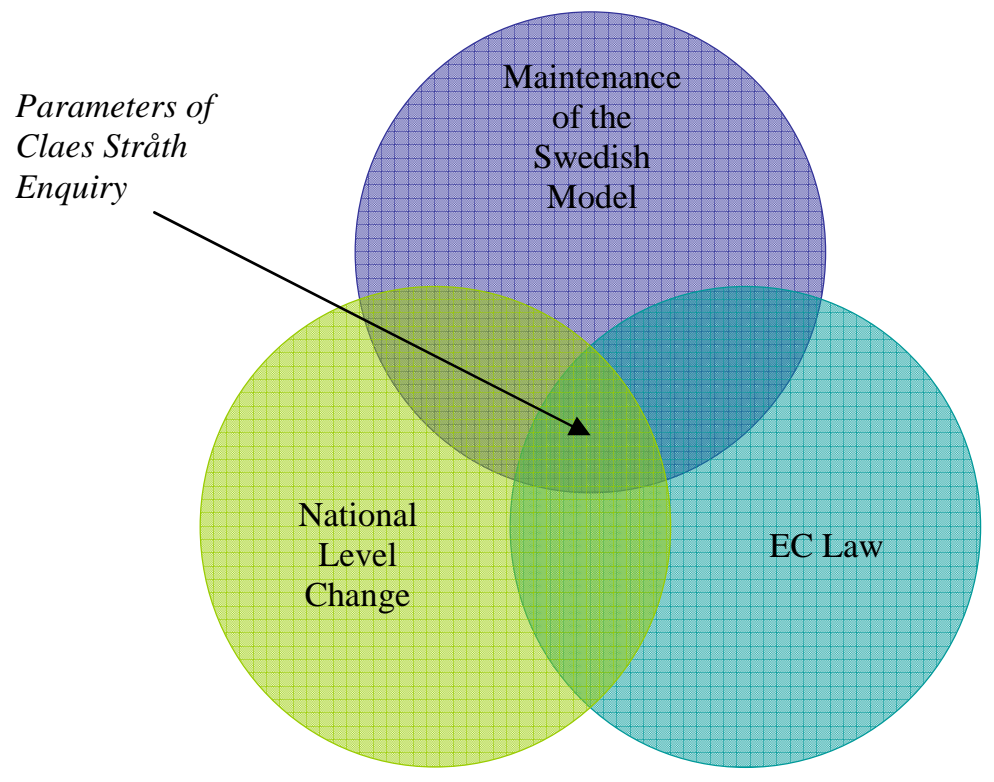

Figure 5.2 Parameters of Claes Stråth Enquiry

Thus, only a limited range of tools can be used to address the issue. These include: the Co-determination in the Workplace Act (and changes to Lex Britannia); changes to the Swedish Posting of Workers Act; and amendments to rules around industrial action and the transparency of collective agreements. ${ }^{14}$ This is important for a number of reasons. Most notably, it rules out important options which are advocated by key stakeholders. It rules out change at the European Level (either coupled with change at the national level or in separation), an option advocated by some members of

${ }^{14}$ Ibid., 1 . 
political parties. ${ }^{15}$ In addition it rules out the legislated minimum wages model which prominent employer representatives argue should be included.

\subsection{PERSPECTIVES OF THE SOCIAL PARTNERS}

The above section began the discussion on how the Claes Stråth investigation may constrain the range of possibilities available. In particular, what options can be used in order to buffer the effects of the ECJ ruling. While this is legitimate, the ways in which actors in the Swedish model view this phenomenon vary significantly.

Views on the constraints of the structure and directives of the enquiry vary between different social partners. Depending on its interests, a social partner may view the Claes Stråth investigation either as a process which constrains its interests, or as a well balanced investigation that looks at all options equally and according to their merit. Understanding how the social partners view the Claes Stråth investigation will give this study a richer perspective on the inner dynamics of the Swedish industrial relations model and its propensity for change. This section argues that the social partners view the investigation in one of the two following ways: either as a constraining or aiding process. In addition to assessing the views of the peak-level organisations, it will also discuss smaller affiliate organisations.

\section{Aiding}

The investigation can be seen as an 'aiding process' on two levels: first, some social partners believe that they can influence the enquiry to serve their preferred options. Second, some argue that the enquiry is well run, and ensure the best option is chosen.

The first point, on the ability of actors to influence the investigation in their favour, will be considered. While the government has determined the directives, and it is managed by Claes Stråth, some social partners have felt able to influence the enquiry during the initial consultation period. This is illustrated by comments from government

\footnotetext{
${ }^{15}$ Swedish Parliament, "Response to Interpellations 2007/08: 624, 560, 561, 562, 563 and 582 on Issues on the Occasion of Laval and Rüffert Cases," (Parliamentary Protocol, 2008, May $13)$.
} 
employer organisation SAGE. According to a SAGE senior official, before the directives were decided, they were given ample opportunity to see them and prepare feedback. ${ }^{16}$ In response to his suggestions on the preliminary directives, Official $2 \mathrm{~A}$ of SAGE could see that the suggestions on the preliminary directives had been taken up, altering the final directives. ${ }^{17}$ This illustrates how a social partner was able to influence the directives in a way that was positive for their organisation. ${ }^{18}$

The degree to which this 'influence' is formally institutionalised, however, is not clear. Official 2A of SAGE was unable to gauge whether his influence was official or unofficial. But rather, he stated that 'I was able to have an impact on it'. ${ }^{19}$

Other organisations such as SACO, felt they did not influence the directives. However, SACO did not believe that the government guidelines constrained their particular position. ${ }^{20}$ Further, a senior official of SAGE felt this because the starting point of the investigation was to preserve the Swedish model, and it did not constrain the organisation's position in any way. The official was aware, however, that it is possible to make a wide range of recommendations within the existing directives. ${ }^{21}$

A second point is that most social partners believed that the overall quality of the investigation was high. Some of the social partners praised the composition of the enquiry. Official 2A of SAGE commented that a 'very good investigator was chosen' as:

He is very experienced and a very good listener. He has very good experience of how the organisations work, but also how they are thinking and how they deal with each other. ${ }^{22}$

The SAGE official stated that he was aware that the final verdict by the investigation was likely to be candid. But in light of this, he believed that Stråth was

\footnotetext{
${ }^{16}$ Official 2A, "Interview " (Swedish Agency for Government Employers [SAGE], 2008, October 14).

${ }^{17}$ Ibid.

${ }^{18}$ Ibid.

${ }^{19}$ Ibid.

${ }^{20}$ Official 5A, "Interview," (Confederation of Professional Associations [SACO], 2008, 21 October).

${ }^{21}$ Ibid.

${ }^{22} 2 \mathrm{~A}$, "Interview ".
} 
'exactly the right person to deliver a verdict which everyone can live with and can accept', as he is an investigator who has a low profile and is very willing to listen. ${ }^{23}$

Officials from TCO, LO, and SACO also held a great deal of respect for the Claes Stråth investigation. ${ }^{24}$ They highlighted aspects of the institutional framework, which enhances the legitimacy and quality of the investigation. There was a unanimous impression that Stråth tried to listen and was interested in a solution that all social partners could accept. ${ }^{25}$ Official 5A of SACO in particular believed that for the government to accept a recommendation, agreement from the majority of the social partners was necessary. It is not in Stråth's interest to 'have a proposal that only a few of the social partners can agree upon' ${ }^{26}$ Similarly, Official 2A believed that it was wise to have an investigation where the social partners are members and enhances the possibility to give input. ${ }^{27}$

Most social partners emphasised the role of the Claes Stråth investigation as an 'aiding institution'. However, this view was not universal.

\section{Constraining}

Swedish Enterprise and Teknikföretagen held strong views concerning the constraining effects of the investigation. They saw the Claes Stråth investigation as a constraining process on three different levels: first, with regards to the directives set by the government; second, with regards to the overall quality of the investigation and its ability to make recommendations which are in compliance with EC law; and third, with regards the social partners' lack of ability to influence the direction of the investigation.

To begin, these groups emphasised the restrictive nature of the directives. A strong perception, particularly from the side of the employers is that the parameters of the enquiry were too narrow and subsequently could not take into account the full range of options discussed in Chapter Four. According to senior Official 1A of Swedish Enterprise:

\footnotetext{
${ }^{23}$ Ibid.

${ }^{24}$ Official 3A, "Interview," (Swedish Trade Union Confederation [LO], 2008, October 15), Official 4A, "Interview," (Swedish Confederation of Professional Employees (TCO), 2009, February 24), 5A, "Interview."

${ }^{25} 5 \mathrm{~A}$, "Interview.", 4A, "Interview.", 3A, "Interview."

${ }^{26} 5 \mathrm{~A}$, "Interview."

27 A, "Interview ".
} 
[Claes Stråth's] mission is obviously too tight. He should have a mission: we have the Laval case, what changes are preferable in Sweden - that, or that, or that. Now they have said that [he] should provide a solution in a certain way. ${ }^{28}$

Similarly, Official 1B of the Engineering Employers (Teknikföretagen) believes that the parameters were so restrictive that they have prescribed a predetermined outcome. Both officials from Swedish Enterprise and Teknikföretagen were adamant that the narrow scope of the investigation is the consequence of a political imperative. The government gave the mission to Stråth and required that the outcome be in accordance with the Swedish Model. ${ }^{29}$ It seeks to preserve the model that has always regulated the labour using collective agreements. According to Official 1A of Swedish Enterprise, 'in my opinion we don't have a Swedish model for foreign employers. ${ }^{30}$ An important restriction imposed by the government is that they do not plan to make any changes to labour legislation. ${ }^{31}$ Thus according to Swedish Enterprise, the current government is as restrictive as the prior Social Democratic government.

As a result of the narrow scope of the Claes Stråth investigation, Official 1A of Swedish Enterprise stated that: 'it is difficult for us to make a standpoint if we don't have the other option. ${ }^{32}$ This may help to explain their lack of a stated position as discussed in Chapter 4.

A second constraint imposed by the investigation is its inability to make proposals that are in line in European legislation. This is believed by some to be caused by a poor quality investigation overall. Teknikföretagen had some of the strongest opinions on this matter:

I wouldn't describe the investigation as a real investigation. I would say the government has....it is like the ordering of a dish. I want salmon today. There is no investigation. ${ }^{33}$

\footnotetext{
${ }^{28}$ Official 1A, "Interview," (Confederation of Swedish Enterprise, 2008, October 15).

${ }^{29}$ Ibid.

${ }^{30}$ Ibid.

${ }^{31}$ Ibid.

${ }^{32}$ Ibid.

${ }^{33}$ Official 1B, "Interview," (The Association of Swedish Engineering Industries

[Teknikföretagen], 2008, October 30).
} 
Swedish Enterprise held much of the same opinion, albeit to a less explicit degree. The representative of Swedish Enterprise felt that the Claes Stråth investigation may not be able to make proposals that are compatible with ECJ law. For this official, the investigation raises many legal questions, of which the most important is to find a solution that is in complete accordance with EU legislation.

Official 1A of Swedish Enterprise official raised the Danish example, which he believes is in not in accordance with EU legislation. It was argued that if Sweden follows a similar path it could face comparable problems. While no legal challenges have yet been made against the Danish model at the European level, it is likely that it will become an issue in the future. According to Official 1A of Swedish Enterprise:

They don't mind waiting ten or so years until the ECJ says that we are wrong. They can live with that. ${ }^{34}$

This suggests that Sweden's government may also be willing to make use of the time delays associated with such legal cases to extend the 'life-period' of an existing institutional arrangement. However, both Swedish Enterprise and its affiliate Teknikföretagen expressed the desire for a better solution.

A third constraint is the inability of the respective parties to influence the investigation. Swedish Enterprise had recommended that the enquiry consider the legislated minimum wage option, but this advice was not taken into account. ${ }^{35}$ Teknikföretagen also recognised that the clear signal has been made that legislated minimum wages will not be included. ${ }^{36}$

Another issue that has not been addressed is the potential incompatibility with European law. Officials from both Swedish Enterprise and Teknikföretagen have raised this concern. Nonetheless, both parties believe that this issue was not taken into account.

In contrast to the government employers (SAGE), the private employers and engineering employers association feel that they have not been successful in influencing the directives of the Claes Stråth investigation. This is likely to be

\footnotetext{
${ }^{34} 1 \mathrm{~A}$, ,Interview."

35 Ibid.

${ }^{36} 1 \mathrm{~B}$, "Interview."
} 
associated with the type of recommendations made by the respective organisations. The recommendation by SAGE was made on an issue that Stråth had some flexibility over. $^{37}$ On the other hand, private employers wanted to make changes to the core directives of the enquiry. Neither their reasoning, nor their influence as social partners, was able to shift the core directives concerning these issues.

These arguments by the social partners suggest that the structure and directives of the Claes Stråth investigation were created in order to protect and ensure continuity for the Swedish model. In particular, the structure and directives are the result of feedback effects in the existing institutional arrangements. The equilibrium that has been created around the Swedish model is difficult to shift.

The Claes Stråth investigation also has displayed contingent effects, which are a feature of path dependent processes. The structure of the enquiry has the consequence of restricting which actors will be heard and those that will not. Once the structure was decided, it made it difficult for actors with alternative - such as Teknikföretagen - to gain any real influence. Similarly, the government directives affected the social partners' ability to propose options. Ruling out a legislated minimum wage resulted in Swedish Enterprise - the largest private sector employers representative - being unable to formulate a position. This led to a significantly reduced voice for the private sector firms it represents.

This observation of 'inertia' and 'contingency' illustrates how the institutional structure of the Claes Strath enquiry has amplified the pressure to maintain the 'Swedish model', whilst dampening the internal forces seeking substantial change.

The next section will discuss the impact of current renegotiation of the 'Head Agreement' between the core social partners on the Claes Stråth investigation. It will assess the issue of timing and sequencing and its role in 'issue linkage'. A particular focus will be the role of the Head Agreement negotiations in altering bargaining power, which will provide the opportunity for actors to limit the options within the Claes Stråth investigation. Thus, the following section will discuss the 'Head Agreement' on the Swedish model and its impact on legislated minimum wage option.

\footnotetext{
${ }^{37}$ Karl Pfeifer, "Laval-Utredningen (Laval-Investigation)," (Swedish Agency for Government Employers [SAGE], 2008).
} 


\subsection{THE HEAD AGREEMENT}

The impact of the renegotiation of the 'Head Agreement' on the Laval problem (in particular the Claes Stråth investigation) is subject to competing opinions. What makes this issue so important is that the Saltsjöbaden Agreement (Head Agreement) is the foundation of the Swedish model. As a result, it is relevant to any debate over change to the Swedish model. It forms the basis of the partnership between employers and labour and outlines the terms and conditions upon which the partnership is founded. This section assesses how the conditions placed on the renegotiation of the Head Agreement are likely to affect the Claes Stråth investigation. In particular, LO does not want to renegotiate the agreement if Swedish Enterprise advocates the legislated minimum wage option. This section will determine whether LO's influence (and pressure for the autonomous collective agreement model) is amplified by the simultaneous renegotiation of the 'Head Agreement'. This may explain why Swedish Enterprise has come to no official position in the Claes Stråth investigation.

\section{Context}

The renegotiation of the 'Head Agreement' (successor of the 1938 Saltsjöbaden agreement) is important here due to its particular timing in relation to the Laval problem and the Claes Stråth enquiry. As it is the founding agreement of the Swedish model, renegotiating a new Head Agreement is of high importance to the main social partners. The close proximity of the renegotiation to the Claes Stråth investigation has led to concerns that it is being used as a tool to limit the options of the social partners.

The Head Agreement is a bipartite agreement between Swedish labour and industry concerning rules around collective bargaining and general labour conditions and regulation. The original Saltsjöbaden agreement came about in 1938 between the LO and the SAF after a period of intense conflict resulting in significant number of working hours lost in both industrial action and employers blockades. It was the founding document of a new era of industrial peace between the social partners without the involvement of the state. ${ }^{38}$

\footnotetext{
${ }^{38}$ Nils Elvander, " Two Labour Market Regimes in Sweden," Industrielle Beziehungen. 10, no. s (2003): 147-49.
} 
This state of co-operation characterised the relationship between the social partners for a period of 30 years before piecemeal labour legislation partially eroded the autonomy of the social partners in wage bargaining processes. ${ }^{39}$ In 1997 a new Industrial Agreement (IA) was made which embodied the majority of the characteristics and 'spirit' of the 1938 agreement. $^{40}$ In 2008, the social partners started to renegotiate this 'Head Agreement', which outlines the level of agreement and cooperation from both sides of the social partners.

The bi-partite agreement can therefore be characterised as the 'foundation' of the Swedish model. If it is not renegotiated, the state is likely to come into the labour market, which suggests an end to the Swedish model. As a result, the social partners concerned want the new Head Agreement to be renegotiated, but both have conditions that need to be met before they finalise a new agreement. The timing of the renegotiation has been influential in tipping the balance of power between the main social partners.

A parallel can be drawn between the impact of the negotiation of the Head Agreement and the effect of other 'negotiations' taking place at the same time as the 'Laval dispute' (and the Claes Stråth investigation). For example, some employee representatives and (left-wing) political representatives saw the Laval case as a tool to prevent Lisbon Treaty ratification. This did not eventuate, however, as both the LO and SAP refrained from officially linking the two issues. The timing of these two issues were somewhat pivotal in the attempts (albeit failed) to gain leverage during the ratification of the Lisbon Treaty by Swedish parliament.

This suggests that the issue of timing is also important in the Claes Stråth investigation. One possibility is that without agreement on the recommendations to the Claes Stråth investigation, LO will not engage with the Swedish Enterprise in the renegotiation of a new Head Agreement. It can be identified that in the renegotiation of the Head Agreement labour holds a powerful position. According to Swedish Enterprise, the right to industrial action and sympathy action is a powerful tool currently held by labour which can be used at will against employers. According to Official 1A of Swedish Enterprise:

\footnotetext{
${ }^{39}$ Ibid.: $147-50$.

${ }^{40}$ Ibid.: $155-59$.
} 
Our major problem is the sympathy action. It is the most powerful collective action in the trade unions tool box. There is no doubt about that. ${ }^{41}$

Employers believe that the unions' use of collective action is a source of power imbalance between the two groups.

The timing of the renegotiation of the Head Agreement has shaped the bargaining power held by the main social partners. It presented the opportunity to link the Head Agreement with the Claes Stråth investigation and allowed the LO to place conditions on Swedish Enterprise for signing the agreement. It limits the options that can be advocated by Swedish Enterprise as the Head Agreement would only be signed if Swedish Enterprise did advocate the legislated minimum wage model. Renegotiation of the Head Agreement at a different time than the Laval case is likely to have significantly decreased the ability of LO to link the two issues.

This asymmetry in power between the representative of labour and employers has meant that the renegotiation can be used to limit the employers' range of responses to the Laval case. Swedish Enterprise and Teknikföretagen both believe that labour organisations have successfully achieved this. As stated by Official 1A of Swedish Enterprise:

If we don't agree with the trade unions with how to solve the Laval problem, there will not be any head agreement. The things are combined in their world and that is why we do not have any hurry [to make a position]. ${ }^{42}$

This is supported by statements by LO and TCO who view that it is impossible to separate the two issues. ${ }^{43}$

On the other hand, an important leverage point for employers is that there is no deadline by which the new Head Agreement must be finalised. As such, the Claes Stråth enquiry could be over before the Head Agreement negotiations are complete. According to Official 1A:

\footnotetext{
${ }^{41} 1 \mathrm{~A}$, "Interview."

${ }^{42}$ Ibid.

${ }^{43}$ 4A, "Interview."
} 
We have no date, we have said until next year we will negotiate. Whether this happens or if the negotiations break down I don't know. ${ }^{44}$

In other words, the flexibility around when the agreement must be concluded, gives Swedish Enterprise some leverage over the impact of the 'Head Agreement' on limited legislated minimum wages from the positions put to the Claes Stråth investigation.

While labour has some important issues on which it is unwilling to compromise, this suggests that Swedish Enterprise also has some pressing issues on which it is reluctant to negotiate. The degree to which each can protect its 'non-negotiable' territory is a product of their relative strength in negotiations.

According to Official $1 \mathrm{~A}$ the potential for sympathy action during the Laval case was a critical danger for Swedish Enterprise. In the words of the official:

One thing that hasn't been mentioned so much. The two trade unions which where active were the trade union and the electricians. But there were lots of other trade unions which were going to take sympathy action. The sympathy action was going to involve 43, 000 of our members. That is why it is such an important issue for us. And we have given money to Laval in the trial, so we sponsored their procedure both before the ECJ and Swedish Labour Court. Because the issue concerns so much of our member companies. We have 55, 000, and of those 43, 000 were actually involved. ${ }^{45}$

This suggests that there are certain 'sticking' points that employers are not willing to negotiate. And as a consequence, the Head Agreement, in which labour has extra bargaining power vis-à-vis the employers, is being used as a 'safeguard' and limit the possible changes to the Swedish model that will be considered by Claes Stråth in the government investigation.

The result of the asymmetry in power between the main social partners is that the legislated minimum wages option has been excluded as an option for Swedish Enterprise at the request of LO. As stated in previous chapters, Swedish Enterprise has not taken an official position toward the Laval case. The two possible explanations are:

\footnotetext{
${ }^{44} 1 \mathrm{~A}$, "Interview."

${ }^{45}$ Ibid.
} 
first, Swedish Enterprise does not have or know a position it wishes to advocate; or second, it is not disclosing its position for tactical reasons.

Swedish Enterprise has raised problems with all of the major positions put forth. An important observation, however, is that its largest and most important affiliate, the engineering employers, stated in an extensive position paper that its preferred option is a legislated minimum wage.

The LO has stated that there are areas which they are not willing to negotiate upon, particularly those that will cause a large deviation from the Swedish model. According to the LO's own officials, a legislated minimum wage falls into the category of a 'large deviation'. ${ }^{46}$ Thus, there is evidence to support Official 1A's claim that particular conditions have been put on Swedish Enterprise in the renegotiation of the Head Agreement. In other words, advocating a legislated minimum wage option or another 'large deviation' will lead to a breakdown in negotiations.

This line of reasoning, however, can be criticised by an alternative explanation. It is possible that that if Swedish Enterprise states a position that conflicts with the current government, it could result in negative implications for their re-election. According to Official 1B, however, this conclusion is 'ill founded on an intellectual level'. ${ }^{47}$

While it is evident that legislated minimum wages were excluded in the directives of the Claes Stråth investigation, there is evidence that this option would have been removed from the table in any case. An important variable of change would be if the Claes Stråth investigation parameters were to include a legislated minimum wage. In this case, it could be seen whether Swedish Enterprise was willing to forgo the renegotiation of the new Head Agreement in favour of the possible implementation of legislated minimum wages. Given the widespread opposition to this option, it is unlikely that this gamble would have succeeded. Furthermore, this presupposes that legislated minimum wages are the preferred option of Swedish Enterprise.

The engineering employers may have taken a different approach, as they are willing to forgo the main agreement if their position can be improved (for example, by implementing a legislated minimum wage). ${ }^{48}$

\footnotetext{
${ }^{46} 3 \mathrm{~A}$, "Interview."

${ }^{47} 1 \mathrm{~B}$, , "Interview."

${ }^{48}$ Ibid.
} 
In summary, the renegotiation of the Head Agreement has several implications for the Claes Stråth investigation. The Head Agreement seeks bi-partite industrial peace between labour and industry and the renegotiation has particular ramifications for the process of institutional change. Its timing alongside other events such as the Lisbon Treaty ratification and the Laval case provided the opportunity for the multiple issues to be negotiated in tandem. This has the effect of influencing the level of 'bargaining power' held by the main social partners. In particularly, it magnifies the asymmetry in power between labour and employers. The current renegotiation of the Head Agreement has been used to take legislated minimum wages off the agenda for Swedish Enterprise. This was done by LO placing certain conditions on the Head agreement, meaning that if Swedish Enterprise were to advocate a legislated minimum wage, the negotiation would break down. Thus, there is evidence of a coupling between the Head Agreement and the Claes Stråth investigation.

\subsection{CONCLUSIONS}

In assessing the impact of the Claes Stråth inquiry in the context of the current Laval problematic, the following findings were reached. First, the structure of the enquiry was found to be important. The enquiry was driven in a unilateral manner, by the state and its representative, Claes Stråth. Its uni-dimensional nature was further reinforced by the presence of a single chair. Despite these factors, the enquiry was found to have a very wide consultation process that involved academic experts, government officials, and social partner representatives.

The manner in which the social partners were consulted was revealing. Only peak level organisations were consulted. This is not unusual, and somewhat intuitive, given the timeframe of the investigation. However, this mode of representation does have the effect of missing the key divisions and minority viewpoints that exist within peak level organisations. As the peak-level social partners are divided along class lines, this effectively suppressed cross-class positions. This is particularly salient for Swedish Enterprise, an organisation that represents 40 sectoral and employers associations. The Claes Stråth investigation has no formal way of understanding the internal factions that may divide these larger organisations. 
In saying this, however, evidence from an interview with Claes Stråth does suggest that he is aware of the factions that exist within Swedish Enterprise. But ultimately, including only peak level representatives in the reference group, served to dilute diverging positions which exist at lower levels.

The second conclusion of this chapter concerns the directives that the government issued to the enquiry. These directives $d o$ have a constraining effect on the type of options which can be looked at by this study. Their objective is to maintain social partner autonomy in the wage setting process (therefore excluding a legislated minimum wage). A further constraint is that they give the enquiry scope to look at changes only at the national level, excluding the possibility of change at the European level. This only leaves several organs that can be used including the Swedish Posting of Workers Act, changes to the Lex Britannia, legislation around social partner 'conduct', and the right to industrial action. This leaves only a very narrow scope for the investigation (see previous Figure 5.2).

The third conclusion of this chapter concerns the opinions of the social partners on the role of the Claes Stråth investigation as an aiding or constraining process. The opinions toward the Claes Stråth investigation were strongly polarised. First, there were those social partners which perceived the investigation as having an aiding effect. The majority of the peak level social partners (SAGE, LO, TCO, and SACO) saw the investigation as being 'well run' and suited for determining the optimal solution to the problem. Some actors (in particular SAGE) felt they were able to influence the investigation in their favour. In other words, the directives were flexible enough to adjust to concerns raised by the relevant actors.

Other social partners viewed the investigation as having a constraining effect. This perspective was held by the peak level organisation Swedish Enterprise and its affiliate organisations Teknikföretagen and EIO. These actors argued that the directives of the investigation were too narrow. In contrast to the actors above, they felt they were unable to influence the investigation. A point does need to be made that their demands fell outside of the enquiry's core directives. This provides an explanation for the investigation's lack of flexibility in this area. A further criticism voiced by Teknikföretagen was that the investigation was of 'poor quality' and as a result would make proposals that are inconsistent with European law. 
In aggregate, the Claes Stråth investigation promotes continuity of the Swedish labour relations model. It does this by dampening (and in the case of the legislated minimum wage eliminating) those positions which seek change. Concurrently, it provides government mandated legitimacy for options that are consistent with the Swedish model.

The investigation further consolidates the peak-level organisations as the core 'voices' in the current discussion. It has the effect of excluding positions that are mobilised along cross-class lines and incapable of gaining support from a peak level social partner. Positions that form along class lines (for example, within blue-collar workers represented by LO, or white-collar workers represented by TCO) do have an influential representative institutionally located within the enquiry.

Thus, the enquiry plays an important role in channelling positions, amplifying the influence of some options. This is linked to the purpose of the inquiry that is to find the intersection between maintaining the Swedish model, making changes at the national level, and ensuring Sweden's consistency with European law. 
1A, Official. "Interview." Confederation of Swedish Enterprise, 2008, October 15.

1B, Official. "Interview." The Association of Swedish Engineering Industries [Teknikföretagen], 2008, October 30.

2A, Official. "Interview ": Swedish Agency for Government Employers [SAGE], 2008, October 14.

3A, Official. "Interview." Swedish Trade Union Confederation [LO], 2008, October 15.

4A, Official. "Interview." Swedish Confederation of Professional Employees (TCO), 2009, February 24.

5A, Official. "Interview." Confederation of Professional Associations [SACO], 2008, 21 October.

Elvander, Nils. " Two Labour Market Regimes in Sweden." Industrielle Beziehungen. 10, no. s (2003): 146-59.

Employment, Ministry of. "Committee Terms of Reference ": Consequences of action in response to the Laval judgment; decision at a Government meeting on 10 April 2008.

Parliament, Swedish. "Response to Interpellation 2007/08:483 on the Investigation in Response to the Laval Case." Parliamentary Protocol, 2008, March 10.

"Response to Interpellations 2007/08: 624, 560, 561, 562, 563 and 582 on Issues on the Occasion of Laval and Rüffert Cases." Parliamentary Protocol, 2008, May 13.

Pfeifer, Karl. "Laval-Utredningen (Laval-Investigation)." Swedish Agency for Government Employers [SAGE], 2008.

Stråth, Claes. "Interview." National Mediation Office, 2008, October 30. 


\section{What This Tells us About the Swedish Model}

The previous chapters described and analysed the competing 'tensions' within the Swedish model. This analysis took a two-fold path. First, Chapter Four investigated the official positions of the social partners. Second, Chapter Five assessed how the Claes Stråth investigation constrained some positions, while aiding others. Chapter Five also placed the enquiry in the context of the current renegotiation of the Head Agreement and considered how the negotiation might alter the degree of bargaining power between the social partners. Ultimately, these chapters identified a strong imperative for continuity within institutions and social partners. These issues all lead to the wider concern of the relevance of these observations to change in the Swedish model of industrial relations.

This chapter approaches the issue of institutional change in two parts. First, it will assess whether or not change is occurring. From this point it will discuss what this study can deduce about the interests of actors and the internal dynamics of institutions. The second part of the chapter returns to the theoretical models from Chapter Three to assess which best explains the empirical findings. The models are the "convergence model', the 'punctuated equilibrium model' (Krasner) and the 'incremental transformation model' (Thelen).

\subsection{IS CHANGE OCCURING?}

The conclusion drawn from the preliminary chapters is that the ECJ ruling has not yet resulted in real change for the Swedish model. This is deduced from the empirical findings of the previous chapters, assessed against the criteria that this study uses to define real change (see Section 3.2). Internal pressures are not yet of sufficient magnitude to threaten the core features of the Swedish model as defined in Chapter Three. 
First, this section will make clear what types of change are being considered for the Swedish model of industrial relations. The option that has had the greatest influence is the model of autonomous collective agreements. The range of 'levers' available in the Claes Strath investigation include the following ${ }^{1}$ : limiting unions' right to strike to the minimum terms of the trade agreements (or the 'hard-core' of the PWD); increasing the transparency of collective agreements; permitting industrial action to be taken only if the potential new collective agreement is an improvement on the conditions of the existing collective agreement (albeit within the hard-core of the Posting of Workers Directive); giving a greater role to the Swedish Liaison Office (Work Environment Authority); amending the Swedish Posting of Workers Act (1999:678); and amending the Co-determination in the Workplace Act.

These are likely to be the 'tools' used to respond to the issue. ${ }^{2}$ It is likely that there will be an increase in legislation that encroaches upon some aspects of the labour market. In addition, the Work and Environment Authority may play a greater role that may also be perceived as an increasing role of the state labour markets. Some restrictions are likely to be applied to the right to strike, not allowing unions to go further than what is defined as the hard-core of the Posting of Workers Directive.

What this study finds, however, is that the changes that are being considered are marginal and do not qualify as 'substantive' or real change. The 'core areas' of the Swedish model are projected to remain unchanged. ${ }^{3}$ Figure 6.1 provides a diagram of what constitutes change. The areas that this study identifies as unchanged primarily revolve around social partner autonomy in particular key areas, such as wage setting.

\footnotetext{
${ }^{1}$ An important issue is that although the Claes Stråth investigation recommendations were released on December 2008, these were not final. They are subject to scrutiny by the social partners and the public. Only when parliament officially votes for any changes, can it be said with any concrete certainty what changes have taken place. This is unlikely to happen before late 2009/10

${ }^{2}$ Claes Stråth, "Action in Response to the Laval Judgement," (State Public Enquiry, 2008).

${ }^{3}$ See Section 3.6
} 


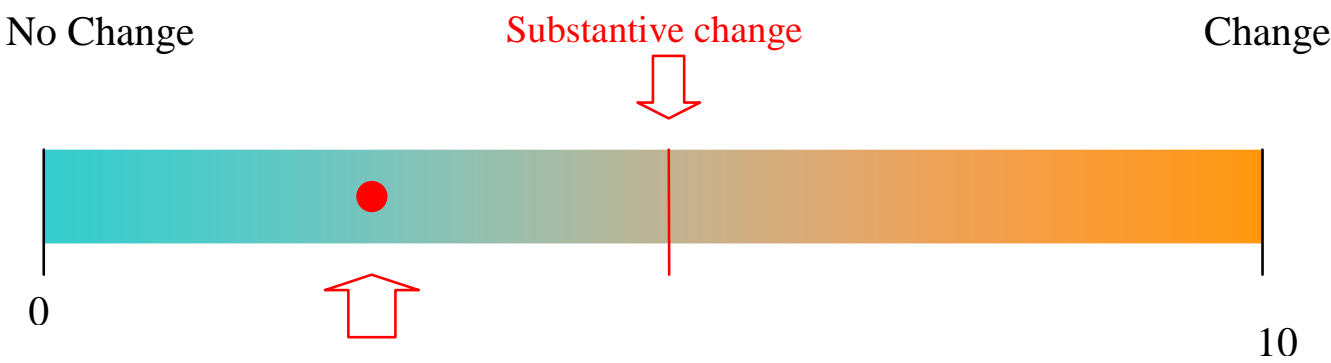

Effect of the 'Laval Case'

Figure 6.1 What constitutes change

A core indicator of continuity is that wage formation is still decided by the social partners. The peripheral legislation that is likely to arise will not undermine this. Alongside this, strong social partners are still present and these changes do not lead to implications for rates of unionisation. A further aspect is that political parties do not deal with labour market issues, as they are left in the realm of the social partners. Unions also retain the right to industrial action. This right may be limited in that unions cannot strike to force employers to take up a collective agreement that has worse conditions for employees. But it is seldom in the interests of unions to worsen conditions for members. Swedish Enterprise and Teknikföretagen argue that restrictions on unions' rights to strike outside the hard-core of the Posting of Workers Directive may help to clarify Swedish model rather than change it. There has been no real change to the degree of bargaining centralisation. In addition, the Laval case has not raised any implications for the use of active labour market policies or public employment. As a result, the response to the ECJ ruling has caused no overall change to the core 'ends' of the Swedish model: high aggregate wages, wage restraint, wage solidarity, and strong worker protection. 


\subsection{ACTORS AND LABOUR MARKET CHANGE}

Interests of Actors

The interests of actors show where areas of tension and pressures for change may exist in the Swedish labour market system. The discussion of the literature in Chapter Two gave an overview of how their interests may influence a model of industrial relations.

Power Resource Analysis (PRA) suggests that Swedish industrial relations are the result of benefits gained by labour as a result class-related collective action. According to a labour-centred analysis, we should expect employers to be in favour of a shift to lower wages. This is based on the assumption that the current model of industrial relations reflects an imbalance in power toward labour. This implicitly assumes a degree of class solidarity based on shared interests. As a consequence, an assumption often attributed to employers is their desire to keep wages low.

The findings from Chapter Four illustrated that low wages are not necessarily a priority for Swedish employers in both the private and public sectors. Instead employers desire a strong degree of stability and a steady labour supply. This desire to maintain a reliable and skilled labour force was indicated to be more important than the raw drive for lower wages. Alongside stability, an important interest for employers is to keep the state out of the wage setting process.

Pressure for more flexible and lower wages came from the Association of Swedish Engineering Industries (Teknikföretagen). This correlates to the welldocumented split between the employers in what are to be considered the 'protected' versus the 'exposed' industries. ${ }^{4}$ Teknikföretagen, the representative of engineering employers, a highly exposed sector, have long been a strong proponent of change within the Swedish model. ${ }^{5}$

In the current debate on the Swedish model, there is little internal pressure from the social partners to bring the state into labour relations. An examination of why most

\footnotetext{
${ }^{4}$ Peter Swenson and Jonas Pontusson, "The Swedish Employer Offensive against Centralized Wage Bargaining," in Unions, Employers, and Central Banks: Macroeconomic Coordination and Institutional Change in Social Market Economies ed. Torben Iversen, Jonas Pontusson, and David Soskice (Cambridge University Press 2000).

${ }^{5}$ Ibid.
} 
actors are against this type of substantial change to the Swedish model is also revealing.

The majority opposed change to the Swedish model in the form of legislated minimum wages. Social partners were particularly concerned that a system of legislated minimum wages would encourage a politicisation of the wage-bargaining process. This was identified as a concern by all of the peak-level employer and labour representatives. It suggests a strong desire to maintain the 'cartel-like' organisation of the wage-setting process. Thus, in some sense there is a cross-class alliance to maintain this. This can be illustrated by the consensus reached by all sides of the social partners. The fact that employers want a labour market in which the state is not involved in the wage-setting process appears to have been a strong sticking point.

These findings suggest that politicians have quite different incentives to those of both employers and employees. One aspect is the short-term outlook held by politicians. A partnership between the representatives of labour and employers is believed to provide more effective long-term planning for the needs of those parties it represents. Due to Sweden's relatively low level of experience with this model of employment regulation, it may not be as efficient as for other European countries with a tradition of regulation through legislated minimum wages.

Overall, the loss of the cartel would imply a loss of control for the social partners. Most of the social partners believe that they are able to determine a better and more stable model than the short term incentives associated with a low wage labour force. This suggests that labour and employers share interests that the state could potentially undermine.

However, employers also want an industrial relations structure where unions do not exert a disproportionate degree of influence. Thus, an important demand is to reduce the ability of unions to perform industrial action. ${ }^{6}$ Unions have displayed a far clearer picture of their interests and what they want for the Swedish labour market. Employee representatives have a core imperative to keep the state out of wage-setting institutions. They do not want wages to be driven down and want to keep control of

\footnotetext{
${ }^{6}$ With the final recommendation of the Claes Strath investigation, this has been achieved, albeit not to the degree envisioned.
} 
wage setting. As a result, Swedish unions want to maintain the current system of industrial relations.

\section{Class Solidarity}

Power Resource Analysis, which depicts particular models of industrial relations as the result of class conflict, suggests that classes have a level of unity or 'solidarity' is based on their assumption of shared interests. If this assumption of 'class solidarity' does not hold, it brings into the question the explanatory power of PRA in explaining institutional change in the Swedish case. In other words, labour having greater bargaining power vis-à-vis employers does not appear to be the only reason for Sweden's system of industrial relations system being robust.

There is, however, some evidence to support the existence of class solidarity, particularly on the side of labour. LO, TCO, and SACO, were all unified in their support of the autonomous collective agreement model. This was despite the recognition of diversity and difference between these peak level organisations that have member groups from a range of different industries. A particularly salient observation was the degree to which SACO was willing to put aside the status-quo option if it would harm other unions. Although it would not be affected by this model, SACO was willing to reject it as it would have negative implications for unions belonging to other organisations. Although 'pure self interest' is apparent in some cases, there appears to be a large push to protect the overall class interests in others. This indicates that there is a degree of 'class solidarity' on the side of labour.

An analysis of employers, however, does not indicate the same level of class solidarity. To the contrast, an assessment of the positions of employer organisations provides evidence of critical disagreements and unproductive stale-mates. SAGE, the Swedish Agency for Government Employers, gave a position that was in line with the positions of the peak-level labour representatives. It supported minimum changes to Swedish industrial relations through advocating the extension model. Swedish Enterprise, which is a hugely influential organisation and represents the majority of private sector employers in Sweden, abstained from making an official position. Within its affiliate organisations, significant tensions exist. While internal tensions 
were not explicitly cited by Swedish Enterprise as the reason for its lack of a standpoint, the competing positions among the affiliates suggest otherwise. Thus, there is a clear absence of intra-class solidarity on the side of the employers, as many employers share support with labour for a particular system of industrial relations. This may help explain why the Swedish model has been robust to the challenges of the of the ECJ Laval ruling.

This study identifies that there is class solidarity among employees, but not among employers. Consequently, a shift in power from labour to employers, as a result of the ECJ ruling, has not led to employers acting coherently to oppose the traditional interests of labour in Swedish industrial relations. This suggests that PRA has a limited ability to explain the dynamics of the Swedish labour market in this particular case. Contrary to what we would expect from PRA, there was no major change despite a shift in power from labour to employers. The varying degrees of class-solidarity reflect the mixed interests of the social partners in this case. The next section will look at the role of cross-class alliances.

\section{Cross-class alliances}

Evidence exists to support an explanation that is based on a 'cross class alliance' in which actors from both labour and employers share mutual goals. There appears to be a cross-class alliance with the purpose of keeping the state out.

This is important and it suggests several things. First, it adds support to the initial assumption that Sweden embodies a particular model of capitalism as suggested in the Varieties of Capitalisms literature. The Swedish model, based on solidarism, creates the conditions in which labour is under-priced and there is a scarcity of employees. The compressed nature of wages that is a result forms the basis of the Swedish model. Here the price of labour is taken out of competition which both labour and employers support. Second, it suggests that convergence is buffered as the social partners have chosen not to opt out of the existing system of solidarism.

This is evident as SAGE, SACO, TCO, and LO supported the autonomous collective agreement model (extension model), citing keeping the state out as a prime goal. Furthermore, Swedish Enterprise argued that it too wanted to keep the state out. 
This was a primary reason for its lack of support for the legislated minimum wage option. Thus, there is evidence of a cross class alliance for the purpose of maintaining a cartel by keeping the state out of the wage setting process.

The manner in which this alliance has been co-ordinated is subject to further debate. The social partners stated that there is a large degree of consultation and meeting between the actors, even between employers and labour. On the other hand, it appears to be in all actors' interests to keep the state out, and as such, each may have come to this option unilaterally.

There has been less identifiable support for a cross class alliance with the purpose of bringing the state in, particularly through a legislated minimum wage. Representatives of 'exposed sectors', in particular the engineering sector, have failed to gain sufficient support to bring the state in. In other words, they have not been able to introduce the legislated minimum wage method. Consequently, this model was not considered by the Claes Stråth investigation.

The existence of a cross-class alliance to keep the state out suggests that $\mathrm{VoC}$ is highly useful for explaining the internal dynamics of the Swedish labour market. It shows that a shift in power from employees to employers does not in itself lead to a weakening of the industrial relations model. This is because there is sufficient support from employers to uphold social partner autonomy in the Swedish model. It suggests that employers' interests have not changed significantly as a result of the ECJ ruling. It is the change in employer interests which may give us the greatest indication of 'significant change'. To complement this discussion on the relationship between institutions and actors, the next section will discuss the theoretical models from Chapter three to assess which best explains the empirical findings.

\subsection{MODELS OF CHANGE}

This thesis finds that the Swedish model displays evidence of resilience. This is particularly clear if viewed in the framework of 'punctuated equilibrium' and 'critical junctures'.

The causes of continuity appear to be the result of the following points. First, there is a large impetus by the actors within the Swedish model to maintain the system 
of autonomous collective agreements and keep the state out. This suggests that there is a level of positive feedback between the existing Swedish wage bargaining model and the underlying solidarity between social partners. The solidaristic model, based of compressed wages, is optimal for both employers and employees but requires a level of agreement and co-ordination. Since this process has been long established in Sweden, a degree of inertia has been set in place as a result of increasing returns for both parties.

Second, there are institutional constraints which impede the propensity for change. Specifically, the Claes Stråth investigation has constrained particular options, locking out options for significant change such as the legislated minimum wage model. This particular constraint in the Stråth investigation, however, was established by the centre right coalition government. Commentators have claimed that electoral constraints resulting from public opposition to change have emerged after labour law de-regulation earlier in the government's term.

This is consistent with the concept of 'contingency' from the theory of path dependency. Small events or decisions can have large and enduring consequences if they occur at particular points in time. In the Claes Stråth investigation the legislated minimum wage option was 'locked out' in the directives of the investigation. Consolidating this in the initial directives of the investigation, made any change very difficult; in other words, this small 'contingency' had significant successive effects.

A third cause of continuity appears to be the timing of the renegotiation of the new 'Head Agreement' between key social partners. This led to an asymmetry of power that had the effect of empowering labour. This point reinforces the critical role of 'timing and sequencing' in path dependence processes. In increasing returns arguments, the timing of an event is crucial. This theory holds that 'earlier parts of a sequence are more important than other parts, particularly if an event happens too late. ${ }^{, 7}$ In this case, the simultaneous timing of the Claes Stråth investigation with the renegotiation of the Head Agreement meant the LO could place conditions on the positions put to the Claes Stråth investigation by threatening to withdrawing from the Head Agreement.

There is some evidence to suggest a 'critical juncture' may have occurred under different conditions. An explanation of why it did not occur is that the countervailing

\footnotetext{
${ }^{7}$ Paul Pierson, "Increasing Returns, Path Dependence, and the Study of Politics," American Political Science Review 94, no. 2 (2000): 263.
} 
interests within the Swedish model were not yet powerful enough to instigate its collapse. This section will undertake a short counterfactual exercise to illustrate this point.

We will first consider the actors' positions. Even if Swedish Enterprise officially supported legislated minimum wages, support for the autonomous collective agreement model would continue to dominate. This is due to the majority social partners in favour of this option.

If in addition the Moderate Party built the legislated minimum wage option into the directives of the enquiry, evidence suggests it is unlikely that the Claes Stråth investigation would have concluded with a different outcome. The addition of the legislated minimum wages to the enquiry directives would probably not be sufficient to change the Swedish model.

A critical juncture may have occurred, however, under different circumstances. Were events timed differently, the terms of the discussion would have been significantly altered.

Had the ECJ specified a ruling in the 'narrow' sense, instead of the 'wide sense', the autonomous collective agreement model would have been explicitly ruled out. In this scenario, the structural factors encouraging continuity would be weakened. In other words, a narrow ruling from the ECJ, would enable positions advocating change to be a lot more influential. Thus, the probability of change occurring is significantly enhanced. The concerns of Swedish Enterprise and the Teknikföretagen would be validated; particularly their suggestion that there is inconsistency between the Swedish model of labour relations and EC law. This would authorise the need for some real change, and potentially mobilise more support for the legislated minimum wage option among the social partners.

Similarly, different timings of the renegotiation of the Head Agreement may have resulted in a different outcome, possibly a critical juncture. This is another example of the crucial role of timing. Additionally, if Swedish Enterprise was not willing to meet the LO's conditions - not renegotiating the Head Agreement - it may have led to a critical juncture after a failure of renegotiation. This would enable the constraining structure of the Head Agreement to be relaxed, and substantially increase the range of choices open to actors, particularly Swedish Enterprise. 
From this point, how do we reconcile the actual level of continuity with the possibility of incremental transformation? It is difficult to dismiss any forms of change. The issue at hand is whether the events meet the criteria of the incremental transformation model.

\section{Incremental Transformation}

This section will test the application of Thelen's fivefold typology of incremental change to what has occurred to the Swedish model in response to the Laval ruling.

No evidence for displacement was found from the positions advocated by the social partners. The Claes Stråth recommendations do not give any additional 'power' or status to subordinate institutions. On the contrary, they strengthen and consolidate the role of the social partners as the core actors in the wage setting process. While subordinate institutions may exist, the response to the 'Laval' ECJ ruling did not lead to any amount of power displacement.

The concept of layering, however, is perhaps the one area where a gradual transformation could be seen. But earlier statements suggests that any 'new elements' have not changed the status or structure of existing institutional arrangement. The role of encroaching legislation could be perceived as layering. However, the role of legislation considered in this case does not deviate beyond existing norms, nor does it change the status of the current structure.

Little evidence exists to support the occurrence of drift. In the particular case, no areas of 'neglect' were identified. Again, to reiterate, no proposals indicate any significant shift from the mandated autonomous collective agreement model. Similarly, there is no evidence of exhaustion.

Furthermore the Laval Case does not support an observation of Conversion. In this case there are likely to be new mandates for the Swedish Liaison Office (Work Environment Authority), and changes to the Swedish Posting of Workers Act (1999:678) and Co-determination in the Workplace Act. Any 'new' purpose (for these existing institutions) does not display evidence of conversion. In summary this particular case study does not display sufficient evidence for incremental change. There is the issue, however, that this study is only a 'snapshot' rather than a 
longitudinal study. This study does not suggest that incremental change cannot happen. There are previous studies that show evidence of incremental change. ${ }^{8}$

But, in order to validate these findings, we have to refer back to the methodology noting that this is a single case study and is not capable of capturing longitudinal change. These resulting caveats will be discussed below. Because this study has not shown evidence of 'incremental transformation' it does not preclude it from happening at any other stage.

This study has shown that tensions exist in the following areas, which should be studied for further evidence of change:

(1) how the preferences of actors may be influenced; and

(2) the timing of particular events relating to institutions.

Institutional change may appear as the result of:

(1) sufficient support from actors choosing to replace a system;

(2) capture or drift of particular institutions; and

(3) particular timing of events where power is in favour of the group or groups that have an interest in change.

\subsection{CONCLUSIONS}

This chapter concludes that the ECJ ruling has not prompted immediate substantive changes. The changes that have been identified in Section 6.1 cannot be classified as significant. Despite the observation of continuity and stasis, however, pressures for change do exist within social partners. From the interests of employers, there is a imperative to have stability and a steady labour supply. In addition to this, there is a desire to have social partner autonomy in the wage setting process. These objectives have proven to be more important than a pure desire for lower wages. Employees, on the other hand, have a shared desire to maintain autonomy in the wage setting process.

\footnotetext{
${ }^{8}$ See Wolfgang Streeck and Kathleen Thelen, eds., Beyond Continuity: Institutional Change in Advanced Political Economies (Oxford University Press, 2005).
} 
These interests held by the actors indicate both a level of class solidarity and the presence of cross class alliances. This is important as it provides an indication of where 'ruptures' may form. There appears to be a significant degree of class solidarity on the side of employee associations over a number of areas. On the side of employers, significant division and disagreement exists. This suggests a lack of co-ordination among this group.

There is, however, a general cross class alliance to keep the state out of the wage bargaining process. A countervailing alliance to bring the state in, through legislated minimum wages, was not identified. In an assessment of the role of institutions, it was found that the Claes Stråth investigation had the effect of strengthening the former and dampening the latter.

The final conclusion is which theory of institutional change best explains the impact of the Laval case on the Swedish model. The punctuated equilibrium model proved to be the most useful at explaining this specific case. This was due to its ability to explain the strong forces of continuity that can resist a significant 'shock' to a system. However, this approach was not without limitations - in particular it is not possible to fully assess the merits of this approach in the absence of a 'critical juncture'. Incremental transformation was, however, not as useful at explaining the empirical observations of this situation. While Thelens' fivefold typology has been useful in explaining the behaviour of institutions in response to other 'shocks', it was not able to sufficiently explain the dynamics of this particular case. 
Pierson, Paul. "Increasing Returns, Path Dependence, and the Study of Politics." American Political Science Review 94, no. 2 (2000): 251267.

Stråth, Claes. "Action in Response to the Laval Judgement." State Public Enquiry, 2008.

Streeck, Wolfgang, and Kathleen Thelen, eds. Beyond Continuity: Institutional Change in Advanced Political Economies: Oxford University Press, 2005.

Swenson, Peter, and Jonas Pontusson. "The Swedish Employer Offensive against Centralized Wage Bargaining." In Unions, Employers, and Central Banks: Macroeconomic Coordination and Institutional Change in Social Market Economies edited by Torben Iversen, Jonas Pontusson and David Soskice: Cambridge University Press 2000. 


\section{Conclusion}

\subsection{SUMMARY}

This thesis posed a number of questions on the response of the Swedish model to European integration. Specifically it asked: (1) What are the positions for change held by actors within the Swedish model toward the ECJ Laval ruling (C-341/05); (2) do institutions play a role in shaping the positions of social partners; and (3) what can these findings tell us about the pressures within the Swedish model and its propensity for change? This thesis evaluated these questions through semi-structured interviews, position papers/documents, in the context of academic publications.

The study began by surveying the literature and identified three approaches to the study of institutions. It identified Historical Institutionalism - which emphasise the importance of historical events, temporal processes, and institutional legacies - as the most relevant approach for this study of Swedish labour market institutions. Furthermore, it took the assumption that there are institutionally distinct groupings of countries, rather than viewing all countries to be passing through different stages of the same historical process. From this starting point, three models of institutional change were outlined: convergence, punctuated equilibrium, and incremental transformation. These three theories were assessed against the study's findings.

The Laval dispute was the result of inconsistencies between Swedish and EC law, and also controversy over competing interpretations of EC law. The ECJ Laval ruling was identified as having four core implications for Swedish law. The first of these is that trade unions cannot discriminate on the basis of the nationality of a collective agreement. Second, trade union demands cannot be made beyond the 'hard-core' of the Posting of Workers Directive. Third, the Laval case did not meet the criteria for extending the 'hard-core' on grounds of public policy, public health, or public security. Finally, the ECJ ruled that that Lex Britannia is discriminating toward foreign 
companies. Different actors have viewed the ECJ ruling in three different frames: simplified, narrow, or wide. As a result, actors hold different views on what types of changes to the Swedish model are legally possible to ensure compatibility with EC law.

The Swedish model was identified as having a specific relationship between social partners and wage setting. This includes, strong social partners and high levels of unionisation, political parties that do not deal with labour market issues, wage formation that is decided by the social partners, and the right to strike. These features had their roots in the Rehn-Meidner model and centralised bargaining. As a result, the state plays a large role through 'active labour market policies' and public employment. This results in a model which is characterised by: high aggregate wages, wage restraint (low distribution between wage earners and employers), wage solidarity (low distribution of income among wage earners), and strong worker protection

Employment policies at the European level showed some inconsistency with Swedish law. The three core characteristics of European employment policy were identified as: co-ordinating, legalistic, and liberal. The final part of Chapter Three characterised the three levels of potential change to the Swedish model: legislated minimum wages would represent the most change; erga omnes would result in the least change; and the extension model would result in the least change. The status-quo option, in contrast, would have a dual effect, causing large change for foreign workers and minimal change for domestic workers.

The study found that the extension model, or the autonomous collective agreement model, had the greatest degree of support from the Swedish social partners. This option would result in the least amount of change for the Swedish model. However, the peak-level employers association Swedish Enterprise, along with its affiliate Teknikföretagen, offered a strong critique of this position. The option of erga omnes, or universal declaration of collective agreements, characterised as 'some change', received no support from the social partners. The option of legislated minimum wage, which represented the most change, found no official support among the peak level organisations. Thus, this option was marginalised in much of the public debate. The Swedish Enterprise affiliate organisation Teknikföretagen, however, did hold this as its official position, suggesting that there are some pressures for change. Its influence, however, was constrained by other factors such as the Stråth enquiry and the 
timing of the Head Agreement negotiation. The status-quo option was not held as the first option by any of the social partners, which suggested an overarching aim to maintain the efficacy of the autonomous system for all workers in Sweden.

The positions of the social partners were not, however, equally influential. Existing institutional arrangements shaped the real influence of these positions. In particular, the Claes Stråth investigation amplified some positions and dampened others. The structure of the investigation that only formally received input from the peak-level social partners meant that positions were channelled along class lines. As a consequence, divisions among employers may have led to the 'deadlock' in the official position of the peak-level employer Swedish Enterprise. The wide consultation, however, suggests that the leaders of the enquiry do understand the conflicting positions. In other words, although official positions were withheld by Swedish Enterprise, Claes Stråth did understand the debates and divisions within the organisation. What the Stråth enquiry did, however, was legitimate the peak level social partners as the main actors in the debate.

The directives of the Claes Stråth investigation limited particular options in two ways. First, it did not consider options for change at the European level. Second, it ruled out a large change, particularly in the form of the legislated minimum wage. Thus, options were limited to changes at the national level that do not lead to significant change of the Swedish model.

Some social partners view the investigation as an institution that aids their positions. First, these actors believe they can positively influence the Stråth enquiry. And second, these actors believe the investigation is well run and that it will find the best solution. Other social partners believe that is a constraining institution, and present three arguments. First, they argue that the parameters set by the directives are too narrow. Second, they argue that the investigation is of poor quality and likely to lead to recommendations that are inconsistent with EC law. And third, they believe that they were not able to influence the investigation directives.

The timing of the renegotiation of the new 'Head Agreement' in conjunction with the Claes Stråth enquiry altered the bargaining power of the social partners. This has given the unions the ability to limit options advocated by employers. As a result, Swedish Enterprise claims that the legislated minimum wage option was taken off the 
agenda. The Claes Stråth investigation has acted as an institutionalised constraint that has supported continuity of the Swedish model. These observations enhance our understanding of how actors within the Swedish industrial relations behaved in response to this shock.

Through restricting union activities, the ECJ ruling suggests that power has shifted from employees to employers. However, there was a high degree of intra-class solidarity on the side of labour. In contrast, employers lacked the same degree of solidarity. This questions whether Power Resource Analysis is an effective model to analyse this case. Due to the existence of factions within employers, weakening labour does not necessarily weaken the Swedish model. Thus, looking only at the 'power' held by labour misses the most important tensions.

From a Varieties of Capitalism perspective, a shift in power from labour to employers will not necessarily change Swedish industrial relations. This is particularly true of this case, as the ECJ shock resulted in no major change to the interests of Swedish employers. Thus, a shift in power to employers as a result of the ECJ ruling may not affect the strength of the industrial relations model, as many employers are supportive of the Swedish model. This explanation is supported by the study that showed that some employer representatives (such as SAGE) strongly supported no change to the Swedish model. Continuity is explained by a broad cross-class alliance to maintain social partner autonomy and keeping the state out of wage setting procedures.

When looking at our theoretical models of institutional change, our understanding of change within the Swedish model is enhanced. There is strong evidence that the model is enduring. This can be seen from both the positions of actors themselves and the existence of institutionalised constraints such as the Stråth investigation parameters and Head Agreement.

The punctuated equilibrium theory, of critical junctures followed by periods of continuity, appears to best explain the continuity of the Swedish model in response to the ECJ ruling. What this theory suggests is that other conditions may have resulted in a critical juncture. For example, if the ECJ ruling specified a 'narrow' interpretation instead of a 'wide' interpretation, change may have been forced upon the model.

The incremental transformation model, on the other hand, appeared to be less relevant at explaining the dynamics within the Swedish model in this particular case. 
Institutions within the Swedish model did not display evidence of displacement, layering, drift, conversion, or exhaustion. While incremental transformation was not observed, the institutional continuity was not without internal pressure.

The study identified particular tensions within the model. Some actors, such as Teknikföretagen wanted to change the existing institutional arrangements. In the future, their influence could be magnified by a further shock to the Swedish model, or the timing of important events.

\subsection{CLOSING REMARKS}

The punctuated equilibrium model has proven to be an insightful model for explaining the events following this particular shock to the Swedish model. Punctuated equilibrium explanations have become increasing questioned within political science in recent years, but this case illustrates how it continues to be relevant. The explanatory power illustrated in this study suggests why it has been so popular within the discipline for so many years.

This study has observed that the Laval ruling did not result in a critical juncture; concurrently, the Swedish model has not collapsed, and does not display signs of transformation as a result of the ECJ ruling. Particular factors and characteristics at the domestic level put up large resistance to 'convergence' with other EU states.

As a result, this is a case where national sovereignty in the form of industrial relations has proven 'robust' against the forces of European integration. If and when change does come to the Swedish model, other theoretical models may prove useful.

The study shows that the Swedish model is by no means indestructible. Rather it displayed a weak or fragile side that may undermine it in the future. Another significant shock to Sweden from the ECJ or challenges in the renegotiation of the Head Agreement may result in a 'critical juncture' as elucidated by Krasner. Alternatively, we may see more of what Thelen describes as an incremental transformation as a result of future challenges.

PRA may not be the most useful framework to analyse institutional dynamics when only a minor shock has been observed. In the case of Sweden, the shock was not large enough to shift power to the exposed employers. Furthermore, this study suggests 
that it is not the best framework to use when large divisions exist among, for example, employers. Industrial relations systems that observe fewer divisions among employers may be more effectively explained using a PRA analysis. Therefore, PRA is likely to be more useful for the analysis of such countries, particularly where classes have unified interests.

The events in this study reinforce the importance and relevance of the VoC literature in providing useful insights about various systems of industrial relations. VoC appears to be useful even in a small external shock. It also shows how employers may be important in maintaining a system - or at least, not pressing for change. In this case, the event did not necessarily shift the preferences for employers within the particular model of capitalism found in Sweden.

This suggests that Swedish labour market institutions, both formal and informal, remain relevant and powerful in the face of Europeanisation. The institutions remain strong because the social partners are committed to upholding them, even where it may not be in their immediate (short-term) interests. The diversity within the EU suggests that not all institutional forms will react in the same way as the Swedish model of industrial relations. On the contrary, institutional designs that are less entrenched and enjoy less legitimacy amongst key social partners are likely to be more affected by the Europeanisation.

The next section draws some broader conclusions. Each country and policy area is unique - therefore, before embarking on regional integration a number of factors should be considered. The findings of this study suggest that the success of national labour market institutions will be influenced by the degree of class solidarity or crossclass alliances.

Regional integration will continue and only time will tell if the Swedish model continues to remain robust. If and when it changes, it will be interesting to identify whether change came through a critical juncture or other means (such as incremental change). Tensions and alliances between the social partners are likely to drive much of this change.

From a European perspective, we can identify a number of observations that are important to countries embarking on regional integration. The Laval case confirms a new direction for ECJ rulings, particularly in light of the Viking and Rüffert rulings. 
These cases represent a step-change from the Rush Portuguesa ruling of 1990 which emphasised national sovereignty over community law. The Laval case, by contrast, holds the free-market principles of the EU foremost. In the face of this shock, the Swedish model of industrials displayed a level of resistance, led by active and vocal social partners.

Several areas for further research are suggested by this study. The following questions are raised:

(1) Why is class solidarity, in Sweden, stronger on the side of labour? What factors make employers less united?

(2) Why did Swedish institutional arrangements heighten cross-class alliances to keep the state out of wage formation, and why was there no significant cross-class alliance to bring the state in?

The Swedish Presidency over the European Union began in July 2009 and will continue until December 2009. The focus of the current work programme includes the global financial crisis and climate change, while the impact of EU level institutions on national labour market institutions has not been raised by the presidency. This may be because the social partners and public within Sweden do not perceive EU level institutions as threatening as previously.

For the time being, internal pressures will prove the greatest challenge to the Swedish model of industrial relations. To understand future change, the relationship between institutions and actors should be the area of focus for academics and policy makers. 


\section{Bibliography}

\section{PRIMARY SOURCES}

\section{Interviews}

1A, Official. "Interview." Confederation of Swedish Enterprise, 2008, October 15.

1B, Official. "Interview." The Association of Swedish Engineering Industries [Teknikföretagen], 2008, October 30.

1C, Official. "Interview." Electrical Installer Organization [EIO], 2008, October 29.

2A, Official. "Interview ": Swedish Agency for Government Employers [SAGE], 2008, October 14.

3A, Official. "Interview." Swedish Trade Union Confederation [LO], 2008, October 15.

3B, Official. "Interview." Trade Union of Commercial Employees (Handels), 2008, October 14.

4A, Official. "Interview." Swedish Confederation of Professional Employees (TCO), 2009, February 24.

5A, Official. "Interview." Confederation of Professional Associations [SACO], 2008, 21 October.

6A, Official. "Interview." Moderate Party, 2008, October 15.

Stråth, Claes. "Interview." National Mediation Office, 2008, October 30.

\section{Documents}

Anonymous. "European Communities: Posted Workers Draft Strengthened." European Industrial Relations Review 236 (Sept 1993).

—_. "'Free-for-All' to Follow Eu Ruling." The Local 2007, Dec 27 (April 1995).

. "A Severe Blow to Sweden's Long Standing Collective Bargaining " Radio Sweden 2007, Dec 19.

. "Sweden Disappointed by EU Ruling." The Local 2007, Dec 18

Association of Swedish Engineering Industries [Teknikföretagen], "The Swedish Model after Vaxholm." 2008.

Björklund, Marianne. "Lavalmål Väcker Heta Känslor (Laval Case Arouses Hot Feelings)." Dagens Nyheter 2008, April 23.

Employment, Ministry of. "Committee Terms of Reference ": Consequences of action in response to the Laval judgment; decision at a Government meeting on 10 April 2008.

European Court of Justice. "Judgement of the Court (Grand Chamber)." edited by European Court of Justice, 2007. 
Gellner, Lars. "Laval Ruling Not Suprising - but Welcome." Eurometri Magazine 2008. . "Speech by Lars Gellner, Legal Advisor Labour Legislation, Confederation of Swedish Enterprise." Symposium: The Impact of the Case-law of the ECJ upon the Labour Law of the Member states, 2008, June 26.

. "The Vaxholm Case." Confederation of Swedish Enterprise, 2008.

Johansson, Christin. "Eu-Hot Mot Kollektivavtal Nonchaleras Av Regeringen (the Eu Threat to Collective Agreements Ignored by Government) " Dagens Nyheter 2008, August 18.

Jonsson, Claes-Mikael, and Ingemar Hamskär. "Utredningens Arbete Och Inriktning Några Synpunkter Från Lo and Tco's Företrädarna I Utredningen (Investigation Work and Focus - Some Comments from Lo and Tco's Representatives in the Investigation)." 2008, 30 May.

LO "Efter Lavalmålet - Regeringen Kan Inte Gömma Sig Bakom EU (after the Laval Case - the Governement Can Not Hide Behind the EU)." http://www.lo.se/home/lo/home.nsf/unidView/D2CEA739C99D1D6BC12573D4 00326C0A.

. "Lo Och Svenskt Näringsliv Överens Om Avtal För Utlandsföretag (Lo and the Confederation of Swedish Enterprise Agree on Contracts for the Country's Enterprises)." http://www.lo.se/home/lo/home.nsf/unidView/1D01C118FD05FC82C125706D0 0307950

. "Stråths Utredning Viktig Beslutsingrediens (Stråth Investigation an Important Decision Factor)."

http://www.lo.se/home/lo/home.nsf/unidView/8C779005394A2A74C125748100 $2 \mathrm{~A} 8321$.

_ _ . "Utan Eu-Fördraget Får Juristerna Mer Makt (No EU Treaty Gives Lawyers More Power)." http://www.lo.se/home/lo/home.nsf/unidview/56CE85651EAA30F2C12573FE00 49EA78.

Lundby-Wedin, Wanja, and Erland Olauson. " Without the Eu Treaty Gives Lawyers More Power [Utan Eu-Fördraget Får Juristerna Mer Makt]." Swedish Trade Union Confederation [LO], http://www.lo.se/home/lo/home.nsf/unidview/56CE85651EAA30F2C12573FE00 49EA78.

Ministry of Employment "Employment (Co-Determination in the Workplace) Act." Ministry of Employment, 1976:580.

Ministry of Employment "Foreign Posting of Employees Act." Ministry of Employment, 1999:678.

Parliament, Swedish. "The Current Debate: The Rights of Trade Unions in the Eu." Parliamentary Protocol, 2008, May 12.

. "Response to Interpellation 2007/08:483 on the Investigation in Response to the Laval Case." Parliamentary Protocol, 2008, March 10.

. "Response to Interpellations 2007/08: 624, 560, 561, 562, 563 and 582 on Issues on the Occasion of Laval and Rüffert Cases." Parliamentary Protocol, 2008, May 13.

Pfeifer, Karl. "Laval-Utredningen (Laval-Investigation)." Swedish Agency for Government Employers [SAGE], 2008. 


\section{SECONDARY SOURCES}

Ahlberg, Kerstin, Niklas Bruun, and Jonas Malmberg. "The Vaxholm Case from a Swedish and European Perspective." Transfer 12, no. 2 (2006): 155-66.

Almond, Gabriel, Scott Flanagan, and Robert Mundt, eds. Crisis, Choice and Change : Histoical Studies in Political Development. Boston: Little Brown, 1973.

Arnull, Anthony, and Daniel Wincott, eds. Accountability and Legitimacy in the European Union: Oxford : Oxford University Press, 2002.

Ashiagbor, Diamond. The European Employment Strategy: Labour Market Regulation and New Governance Oxford [England] : New York : Oxford University Press, 2005., 2005.

Bercusson, B. "Democratic Legitimacy and European Labour Law " Industrial Law Journal 28, no. 2 (1999): 153-70.

Bruun, Niklas, and Jonas Malmberg. "The Evolution of Labour Law in Denmark, Finland and Sweden 1992-2003." European Commission: Employment, Social affairs and Equal Opportunities : Labour Law

Capoccia, Giovanni, and Kelemen R Daniel. "The Study of Critical Junctures: Theory, Narrative, and Counterfactuals in Historical Institutionalism." World Politics 59, no. 3 (2007): 341-69.

Christiansen, Thomas, Knud Erik Jorgensen, and Antje Wiener, eds. The Social Construction of Europe: London : SAGE, 2001., 2001.

Cook, Karen Schweers, and Margaret Levi, eds. The Limits of Rationality Chicago University of Chicago Press, 1990.

Cremers, Jan, Jon Erik Dølvik, and Gerhard Bosch. "Posting of Workers in the Single Market: Attempts to Prevent Social Dumping and Regime Competition in the Eu." Industrial Relations Journal 38 no. 6 (2007): 524 - 41.

Crouch, Colin. "Models of Capitalism." New Political Economy 10, no. 4 (2005): 439-56. . "Models of Capitalism." New Political Economy 10, no. 4 (2005).

Davidson, Alexander Two Models of Welfare: The Origins and Development of the Welfare State in Sweden and New Zealand, 1888-1988. Uppsala: Academiae Ubsaliensis, 1989.

EIRO. "Sweden Industrial Relations Profile." European Industrial Relations Observatory, http://www.eurofound.europa.eu/eiro/country/sweden.htm.

Eklund, Ronnie. "The Laval Case." The Industrial Law Journal 35, no. 2 (2006).

Elvander, Nils. "The Labour Market Regimes in the Nordic Countries: A Comparative Analysis " Scandinavian Political Studies 25 (2) , 117-137 (2002). " Two Labour Market Regimes in Sweden." Industrielle Beziehungen. 10, no. s (2003): 146-59.

Eriksson, Kurt. "The Swedish Rules on Negotiation and Mediation." National Mediation Office, 2005.

Esping-Andersen, Gosta. Social Foundations of Postindustrial Economies: New York : Oxford University Press, 1999.

. The Three Worlds of Welfare Capitalism: Princeton, N.J. : Princeton University Press, 1990.

Eyraud, Francois. The Fundamentals of Minimum Wage Fixing Geneva : International Labour Office, 2005.

Falkner, Gerda, and Simone Leiber. "Europeanization of Social Partnership in Smaller European Democracies?" European Journal of Industrial Relations 10, no. 3 (2004): 245-66.

Fligstein, Neil. The Transformation of Corporate Control Harvard University Press 1993. 
Forsyth., Murray. Unions of States : The Theory and Practice of Confederation: New York : Leicester University Press : Holmes \& Meier, 1981, 1981.

Furaker, Bengt, Kristina Hakannson, and Jan Ch. Karlsson, eds. Flexibility and Stability in Working Life: Basingstoke [England] ; New York : Palgrave Macmillian., 2007.

Gerschenkron, Alexander. Economic Backwardness in Historical Perspective. Cambridge: Belknap Press, 1962.

Hall, Peter A., and David Soskice., eds. Varieties of Capitalism : The Institutional Foundations of Comparative Advantage Oxford [England] ; New York : Oxford University Press, 2001.

Hall, Peter A, Rosemary C R. Taylor, and "Political Science and the Three New Institutionalisms." Political Studies Vol. 44, no. Iss. 5 (1996): p. 936 (22 pages).

Harrison, Lisa. Political Research : An Introduction: New York : Routledge, 2001.

Hix, Simon. The Political System of the European Union Houndmills, Basingstoke, Hampshire ; New York : Palgrave Macmillan, 2005, 2005.

Hooghe, Liesbet. The European Commission and the Integration of Europe : Images of Governance Cambridge ; New York : Cambridge University Press, 2001., 2001.

Huzzard, Tony, and Tommy Nilsson. "Dancing Queen? : Partnership, Co-Determination and Strategic Unionism in Sweden " In Strategic Unionism and Partnership :

Boxing or Dancing? , edited by Tony Huzzard, Denis Gregory and Regan Scott: Houndmills, Basingstoke, Hampshire ; New York, N.Y. : Palgrave Macmillan, 2004.

Ikenberry, John, David Lake, and Michael Mastanduno, eds. The State and American Foreign Economic Policy. Ithaca, NY: Cornell University Press, 1989.

Jochem, Sven. "Equality, Solidarity and the Welfare State. The Nordic Employment Performance in Comparative Perspective " In Gösta Rehn, the Swedish Model and Labour Market Policies : International and National Perspectives, edited by Henry Milner and Eskil Wadensjö.: Aldershot, Hants, England ; Burlington, Vt. : Ashgate, 2001.

Kelly, Sean. "Punctuated Change and the Era of Devided Government." In New Perspectives on American Politics, edited by Lawrence Dodd and Calvin Jillson. Washington DC: Congressional Quarterly Press, 1994.

Knopf, Jeffrey W. "Doing a Literature Review."

Korpi, Walter. "Power Resources and Employer-Centered Approaches in Explanations of Welfare States and Varieties of Capitalism: Protagonists, Consenters, and Antagonists." World Politics 58, no. 2 (2006): 167-206.

. "Power Resources Approach Vs. Action and Conflict: On Causal and Intentional Explanations in the Study of Power " Sociological Theory 3, no. 2 (1985): 31-45.

Krasner, Stephen D. "Approaches to the State: Alternative Conceptions and Historical Dynamics " Comparative Politics 16, no. 2 (1984): pp. 223-46.

Lijphart, Arend. "Comparative Politics and the Comparative Method." American Political Science Review 65, no. 3 (1971): 682-93.

LO, Swedish Trade Union Confederation. "The Act on Co-Determination at Work." http://www.lo.se/home/lo/home.nsf/unidView/79A09A1894097983C1256E5100 38D65B

Menz, Georg. "Re-Regulating the Single Market: National Varieties of Capitalism and Their Responses to Europeanization." Journal of European Public Policy 10:4 (2003): 532-55.

Mill, John Stuart. A System of Logic. 8th ed. London: Longmans, Green and Co., 1967.

Milner, Henry. "Gosta Rehn, Civic Literacy, and the Swedish Model " In Gösta Rehn, the Swedish Model and Labour Market Policies : International and National 
Perspectives, edited by Henry Milner and Eskil Wadensjö: Aldershot, Hants, England ; Burlington, Vt. : Ashgate, 2001.

Milner, Henry, and Eskil Wadensjo, eds. Gosta Rehn, the Swedish Model and Labour Market Policies: International and National Perspectives Ashgate Publishing, June 2001.

Öberg, PerOla, and Torsten Svenssen. "Power and Trust: Mechanisms of Cooperation." In Power and Institutions in Industrial Relations Regimes: Political Science Perspectives on the Transitionof the Swedish Model, edited by Torsten Svenssen and PerOla Öberg. Stockholm, Sweden: : National Institute for Working Life 2005.

Petersson, Hermansson O. "Democracy and Leadership. Report from the Democratic Audit of Sweden 1996." Stockholm: SNS, 1997.

Pierson, Paul. "Increasing Returns, Path Dependence, and the Study of Politics." American Political Science Review 94, no. 2 (2000): 251267.

Pierson, Paul, ed. The New Politics of the Welfare State Oxford [England] ; New York : Oxford University Press, 2001.

Pontusson, Jonas, and Peter Swenson. "Labor Markets, Production Strategies, and Wage Bargaining Institutions: The Swedish Employer Offensive in Comparative Perspective." Comparative Political Studies April no. 29 (1996): 223 - 50.

Przworski, Adam, and Feranado Limongi. "Modernization: Theories and Facts." World Politics 49, no. 2 (1997): 155-83.

Reich, Norbert. "Free Movement V. Social Rights in an Enlarged Union: The Laval and Viking Cases before the European Court of Justice " German Law Journal 9, no. 2 (2008): 125-61.

Rueda, David, and Jonas Pontussion. "Wage Inequality and Varieties of Capitalism." World Politics Baltimore: Apr 2000 Vol.52, Iss. 3; pg. 350 (2000).

Scharpf, Fritz W, and Vivien Schmidt, eds. Sweden \& Denmark: Defending the Welfare State in Welfare and Work in the Open Economy Oxford: Oxford University Press, 2000.

Siedentop, Larry. Democracy in Europe. London Penguin Books, 2001.

Streeck, Wolfgang, and Kathleen Thelen, eds. Beyond Continuity: Institutional Change in Advanced Political Economies: Oxford University Press, 2005.

Svensson, Torsten, and PerOla Öberg. "Labour Market Organisations' Participation in Swedish Public Policy-Making." Scandinavian Political Studies 25, no. No. 4 (2002): 295-315.

Sweet, Alec Stone, Wayne Sandholtz, and Neil Fligstein, eds. The Institutionalization of Europe Oxford : Oxford University Press, 2001., 2001.

Swenson, Peter, and Jonas Pontusson. "The Swedish Employer Offensive against Centralized Wage Bargaining." In Unions, Employers, and Central Banks: Macroeconomic Coordination and Institutional Change in Social Market Economies edited by Torben Iversen, Jonas Pontusson and David Soskice: Cambridge University Press 2000.

Swenson, Peter A. Capitalists against Markets : The Making of Labor Markets and Welfare States in the United States and Sweden: New York : Oxford University Press, 2002.

Sykes, Robert, Bruno Palier, and Pauline M. Prior. Globalization and European Welfare States: Palgrave Macmillan 2001.

Thelen, Kathleen. "Historical Institutionalism in Comparative Politics." Annual Review of Political Science Vol. 2: 369-404 (1999).

Thelen, Kathleen, and Sven Steinmo. "Historical Institutionalism in Comparative Politics." In Structuring Politics : Historical Institutionalism in Comparative 
Analysis edited by Sven Steinmo, Kathleen Thelen and Frank Longstreth, 1-33:

Cambridge [England] ; New York : Cambridge University Press, 1992.

Traxler, Franz, and Martin Behrens. "Collective Bargaining Coverage and Extension

Procedures." European Industrial Relations Online (EIRO)

http://www.eurofound.europa.eu/eiro/2002/12/study/tn0212102s.htm.

Twaddle, Andrew C. "Eu or Not Eu? The Swedish Debate on Entering the European

Union 1993-1994." Scandinavian Studies. Lawrence: Spring 1997. Vol. 69, Iss. 2; p. 189 (23 pages) (1997).

Vernby, Kåre. "Classes, Sectors and Political Cleavages." In Power and Institutions in Industrial Relations Regimes: Political Science Perspectives on the Transition of the Swedish Model, edited by PerOla Öberg and Torsten Svenssen, 107-26. Stockholm, Sweden: National Institute for Working Life, 2005.

Vogel, S K. Freer Markets, More Rules: Regulatory Reform in Advanced Industrial Countries Ithaca, NY: Cornell University Press, 1996.

Wallace, Helen, William Wallace, and Mark A. Pollack, eds. Policy-Making in the European Union. Oxford ; New York: Oxford University Press, 2005.

Zysman, J. "How Institutions Create Historically Rooted Trajectories of Growth." Industrial and Corporate Change 3, no. 1 (1994): 243-83. 
Appendices 


\section{Articles 3(1) and 3(8) of the Posting of Workers Directive (Directive 96/71/EC)}

Terms and conditions of employment

Article 3(1)

Member States shall ensure that, whatever the law applicable to the employment relationship, the undertakings referred to in Article 1 (1) guarantee workers posted to their territory the terms and conditions of employment covering the following matters which, in the Member State where the work is carried out, are laid down:

- by law, regulation or administrative provision, and/or

- by collective agreements or arbitration awards which have been declared universally applicable within the meaning of paragraph 8 , insofar as they concern the activities referred to in the Annex:

(a) maximum work periods and minimum rest periods;

(b) minimum paid annual holidays;

(c) the minimum rates of pay, including overtime rates; this point does not apply to supplementary occupational retirement pension schemes;

(d) the conditions of hiring-out of workers, in particular the supply of workers by temporary employment undertakings;

(e) health, safety and hygiene at work;

(f) protective measures with regard to the terms and conditions of employment of pregnant women or women who have recently given birth, of children and of young people;

(g) equality of treatment between men and women and other provisions on nondiscrimination.

For the purposes of this Directive, the concept of minimum rates of pay referred to in paragraph 1 (c) is defined by the national law and/or practice of the Member State to whose territory the worker is posted.

Article 3(8)

'Collective agreements or arbitration awards which have been declared universally applicable' means collective agreements or arbitration awards which must be observed by all undertakings in the geographical area and in the profession or industry concerned. 
In the absence of a system for declaring collective agreements or arbitration awards to be of universal application within the meaning of the first subparagraph, Member States may, if they so decide, base themselves on:

- collective agreements or arbitration awards which are generally applicable to all similar undertakings in the geographical area and in the profession or industry concerned, and/or

- collective agreements which have been concluded by the most representative employers' and labour organizations at national level and which are applied throughout national territory,

provided that their application to the undertakings referred to in Article 1 (1) ensures equality of treatment on matters listed in the first subparagraph of paragraph 1 of this Article between those undertakings and the other undertakings referred to in this subparagraph which are in a similar position.

Equality of treatment, within the meaning of this Article, shall be deemed to exist where national undertakings in a similar position:

- are subject, in the place in question or in the sector concerned, to the same obligations as posting undertakings as regards the matters listed in the first subparagraph of paragraph 1 , and

- are required to fulfil such obligations with the same effects. 


\section{Information Sheet}

Project Title: Industrial Relations and Institutional Change in Sweden

\section{Researcher:}

Kelvin Bannan

BCA, BA (Hons), MA Candidate

Political Science and International Relations Programme

Victoria University of Wellington

New Zealand

Phone: +64-4-463 5233 ext. 8499

Fax: +64-4-463 5414

Cell: +64-21 2632414

Email: kelvin.bannan@vuw.ac.nz

\section{Supervisor:}

Dr. John Leslie

Lecturer

Political Science and International Relations Programme

Victoria University of Wellington

New Zealand

Phone: +64-4-463 9494

Email: john.leslie@vuw.ac.nz

\section{Background Information:}

I am currently writing a thesis for the requirements of a Masters of Arts in Political Science. This study will, on a macro-level, assess the relationship between national level Swedish labour market institutions and EU level supranational labour market institutions. Particularly, whether the 'Swedish Model' is enduring or collapsing due to integration pressures and its impact on the foundations of national systems of capitalism.

This study investigates such arguments in the context of the December 2007 European Court of Justice (ECJ) Laval ruling and changes to Swedish industrial relations. This thesis analyses the positions advocated by unions, employers associations, ministries, and political parties, on strategies to buffer effects caused by the ECJ ruling. 


\section{Role of Interviews:}

The data, collected through semi-structured interviews, will be published in an academic thesis, publications, and presented at academic conferences and forums. Approximately 8 interviews will be conducted, up to a length of 60 minutes.

The interviewee will be identified in the research, unless confidentiality is requested. If this is the case, the material concerning the individual will be presented in a manner which protects the identity of the person concerned.

Interviews will be transcribed by myself, and will be returned to interviewee if requested. All written material will be kept in a locked file and access is restricted to the investigator. All questionnaires, interview notes and similar materials will be destroyed two years after the conclusion of the research.

\section{Questions:}

The questions will cover the following areas:

1. Official position toward the ECJ Laval ruling.

2. How can these changes best be made (institutional constraints).

3. Conflicts within the organisation regarding these positions.

4. Future of the Swedish model.

5. Political constraints.

The interviews will be recorded on an electronic voice recorder and transcribed. You will be given the option of whether you would like to view the transcribed material.

\section{Consent:}

A consent form will be enclosed to ensure that you have an understanding on the nature of questions and use of material so informed consent can be made.

This project has obtained approval from the Victoria University of Wellington Human Ethics Committee. 


\section{III}

\section{Consent Form}

\section{VICTORIA UNIVERSITY OF WELLINGTON \\ CONSENT TO PARTICIPATION IN RESEARCH}

Title of Project: EU Industrial Relations and Institutional Change in Sweden

I have been given and have understood an explanation of this research project. I have had an opportunity to ask questions and have them answered to my satisfaction.

I consent to information or opinions which I have given being attributed to me in any reports on this research.

I would like the tape recordings of my interview returned to me at the conclusion of the project.

I understand that I will have an opportunity to check the transcripts of the interview before publication.

I understand that the data I provide will not be used for any other purpose or released to others without my written consent.

I would like to receive a summary of the results of this research when it is completed.

I agree to take part in this research

I would like a copy of a research report to be sent at the end of the project

Signed:

Name of participant:

Date:

(please print clearly) 


\section{IV}

\section{Interview Schedule}

Social Partners- Employers

Swedish Agency for Government Employers (SAGE)

14 October 2008 1:08:55

The Association of Swedish Engineering Industries (Teknikföretagen)

30 October $2008 \quad 0: 40: 00$

Electrical Installer Organization (EIO)

29 October $2008 \quad$ 0:52:30

Confederation of Swedish Enterprise

15 October $2008 \quad$ 1:04:38

Social Partners- Employees

Swedish Trade Union Confederation (LO)

15 October $2008 \quad 1: 41: 56$

Trade Union of Commercial Employees (Handels)

14 October $2008 \quad 0: 32: 36$

Swedish Confederation of Professional Employees (TCO)

24 February 2009

Swedish Confederation for Professional Associations (SACO)

29 October $2008 \quad$ 1:02:25

Political Parties

Moderate Party

15 October $2008 \quad 0: 37: 10$

Swedish Social Democratic Party (SAP)

Unable to gain interview

Government Agencies

Claes Stråth - Swedish National Mediation Office/ Enquiry Chair Claes Stråth Investigation

30 October $2008 \quad$ 1:08:10

Academics

Torsten Svensson - Professor, Department of Government Uppsala University

28 October $2008 \quad 0: 55: 47$ 